\title{
Localization and dimerization of the $\mathrm{ABC}$ half transporter rAbcb6 as compared to $\mathrm{rAbcb} 7$
}

\author{
Dissertation \\ zur Erlangung des Doktorgrades \\ der Mathematisch-Naturwissenschaftlichen Fakultäten \\ der Georg-August-Universität zu Göttingen
}

vorgelegt von

Ana Jakimenko

aus Moskau, Russland

Göttingen 2006 
D7

Referent:

PD Dr. W. Kramer

Korreferent:

Prof. Dr. R. Ficner

Tag der mündlichen Prüfung: $\quad$ 06.07.2006 
The experimental work of these $\mathrm{PhD}$ thesis was performed in the group of PD Dr. K. I. Hirsch-Ernst, Institute of Pharmacology and Toxicology, Georg-August-University Göttingen.

The experimental work resulted in the deposition of the full coding rat Abcb7 (rAbcb7) cDNA sequence in the EMBL database under accession number AJ621255.

A part of this work is included in the following manuscript, prepared for submission:

\section{Abdul Jalil Y., Ritz V., Jakimenko A., Schmitz-Salue C., Awuah D., Kotthaus A.,} Kietzmann T., Ziemann C. and Hirsch-Ernst K.I. Subcellular localization of rat Abcb6, an ATP-binding cassette half transporter involved in transition metal homeostasis.

The work on this thesis was supported by a fellowship granted by the DFG, GRK 335 . 


\section{Content}

$1.1 \quad \mathrm{ABC}$ proteins and $\mathrm{ABC}$ transporters 1

1.2 Mammalian ABC protein subfamilies 3

1.3 Mammalian ABCB6 and ABCB7 half transporters 5

1.4 Aims 6

$2 \quad$ Materials and methods

2.1.1 Reagents and enzymes $\quad 8$

2.1.2 Kits 9

$\begin{array}{lll}2.1 .3 & \text { Expendable supplies } & 10\end{array}$

2.1.4 Equipment 11

2.1.4.1 Cell culture equipment 11

2.1.4.2 Molecular biology devices 11

2.1.4.3 Appliances for DNA and RNA analyses 12

2.1.4.4 Equipment for protein analyses 12

2.1.5 Experimental animals, cultured cells and bacteria 13

2.1.5.1 Laboratory animals 13

2.1.5.2 Eukaryotic cell lines 13

2.1.5.3 Primary rat hepatocytes 14

$\begin{array}{lll}\text { 2.1.5.4 Bacteria } & 14\end{array}$

$\begin{array}{lll}2.1 .6 & \text { Culture media } & 15\end{array}$

2.1.6.1 Culture media for electro-competent E. coli bacteria 15

2.1.6.2 Cell culture media 16

2.1.6.2.1 Eukaryotic cell line media $\quad 16$

2.1.6.2.2 Primary rat hepatocyte culture media 17

$\begin{array}{lll}\text { 2.1.6.2.3 Cell mounting media } & 18\end{array}$ 
2.1.7 Vectors, antibodies and oligonucleotides 19

2.1.7.1 Vectors 19

2.1.7.2 Antibodies 19

2.1.7.3 Oligonucleotides 20

$\begin{array}{lll}2.1 .8 & \text { Molecular weight standards } & 24\end{array}$

$\begin{array}{lll}2.2 & \text { Methods } & 25\end{array}$

2.2.1 Pretreatment and sterilization 25

2.2.2 Isolation of nucleic acids 25

2.2.2.1 Mini-preparation of plasmid DNA 25

2.2.2.2 Preparation of E. coli stocks 26

2.2.2.3 Endotoxine-free maxi-preparation of plasmid DNA 26

$\begin{array}{lll}\text { 2.2.2.4 Isolation of total cellular RNA } & 27\end{array}$

2.2.2.4.1 RNA isolation according to Chomczynski and Sacchi 27

2.2.2.4.1.1 RNA isolation from cultured mammalian cells 27

2.2.2.4.1.2 RNA isolation from rat organs 28

2.2.2.4.2 Total RNA isolation using TRIzol ${ }^{\mathrm{TM}}$ reagent 28

2.2.2.4.3 RNeasy Mini Kit 29

2.2.2.5 Determination of nucleic acid concentrations 30

2.2.3 Enzymatic modifications of nucleic acids 30

2.2.3.1 Cleavage of plasmid DNA with restriction enzymes 30

2.2.3.2 Dephosphorylation of vector DNA 31

2.2.4 Isolation of DNA fragments from agarose gels 32

2.2.4.1 QIAquick Gel Extraction Kit 32

2.2.4.2 Agarase digestion method 32

2.2.5 DNA precipitation 33

2.2.6 Cloning of DNA fragments 33

2.2.6.1 Topoisomerase-mediated DNA ligation 33

2.2.6.2 Ligation with T4-DNA ligase 34

2.2.6.3 Production of electro-competent E. coli cells 34

2.2.6.4 Transformation via electroporation 35

2.2.7 PCR techniques 35

2.2.7.1 PCR using plasmid DNA as a template 36 
2.2.7.2 Reverse transcription-PCR (RT-PCR) 37

2.2.7.3 5'-RACE-PCR 39

2.2.8 Construction of expression vectors bearing rAbcb6 and rAbcb7 cDNA 41

2.2.9 Sequencing analysis 44

2.2.10 Agarose gel electrophoresis 46

2.2.10.1 DNA gel electrophoresis 46

$\begin{array}{lll}\text { 2.2.10.2 Denaturating RNA gel electrophoresis } & 47\end{array}$

2.2.11 RNA transfer onto nylon membrane (Northern blot) 48

2.2.12 Radioactive labelling of oligonucleotides with ${ }^{32} \mathrm{P}$ and Northern blot hybridization 49

2.2.13 Cell cultures 51

2.2.13.1 Cultivation of eukaryotic cell lines 51

2.2.13.2 Cultivation of primary rat hepatocytes 52

2.2.14 Transfection of mammalian cell lines with expression vectors 52

2.2.14.1 Electroporation of TM3 cells 53

2.2.14.2 Transfection of cell lines with Fugene 6

2.2.15 Localization of fusion proteins in the transfected cell lines 54

2.2.15.1 Immunofluorescence analysis of cultured cells 54

2.2.15.2 Fluorescence microscopy 54

2.2.16 Biochemical protein analysis 55

2.2.16.1 Cell fractionation 55

2.2.16.2 Determination of protein concentration 56

$\begin{array}{lll}2.2 .16 .3 & \text { Immunoprecipitation } & 57\end{array}$

2.2.16.4 Separation of proteins via SDS polyacrylamide gel electrophoresis 58

2.2.16.4.1 Preparation of vertical SDS polyacrylamide gels 58

$\begin{array}{lll}\text { 2.2.16.4.2 Preparation of protein samples } & 60\end{array}$

2.2.16.4.3 Electrophoresis 61

2.2.16.5 Detection of proteins in Western blot 61

2.2.16.5.1 Semi-dry transfer of proteins 62

2.2.16.5.2 Stainings and preservations of the gel 63

2.2.16.5.3 Immunochemical detection of the protein of interest 64 
3.1 Cloning of rAbcb7 and re-cloning of rAbcb6 66

3.1.1 Cloning of rAbcb7 66

3.1.2 Sequence variations discovered in rAbcb6 cDNA during re-cloning $\quad 72$

3.2 Distribution of rAbcb6 and $\mathrm{rAbcb} 7 \mathrm{mRNA}$ in primary rat hepatocytes $\begin{array}{ll}\text { and rat tissues } & 76\end{array}$

$\begin{array}{lll}3.3 & \text { Localization studies of rAbcb6 and } \mathrm{rAbcb} 7 & 78\end{array}$

3.3.1 Characterization of cell lines used for transfection experiments 78

3.3.2 Expression of tagged $\mathrm{rAbcb} 7$ and $\mathrm{rAbcb} 6$ proteins in situ in living cells 81

3.3.3 Co-expression of EGFP- and DsRed2-tagged rAbcb6 and rAbcb7 in mammalian cell lines $\quad 87$

3.3.4 Co-expression of rAbcb6 and rAbcb7 with marker plasmids $\quad 89$

3.4 Subcellular fractionation and immunoprecipitation analyses $\quad 97$

3.4.1 General strategy for optimization of co-immunoprecipitation analysis $\quad 97$

3.4.2 Characterization of tagged $\mathrm{rAbcb} 6$ and $\mathrm{rAbcb} 7$ protein expression in $\begin{array}{ll}\text { subcellular fractions } & 101\end{array}$

3.4.3 Detection of protein-protein interaction via co-immunoprecipitation 102

$\begin{array}{ll}\text { Discussion } & 110\end{array}$

4.1 Re-cloning of the rAbcb6 sequence $\quad 110$

4.2 Subcellular localization of rAbcb6 112

4.3 rAbcb7 cloning, mRNA expression and protein characterization $\quad 112$

$4.4 \quad$ rAbcb6 dimerization partner 114

4.5 Implications for rAbcb6 and $\mathrm{rAbcb} 7$ function and future perspectives $\quad 116$ 


\section{$1 \quad$ Introduction}

\section{1 $\quad \mathrm{ABC}$ proteins and $\mathrm{ABC}$ transporters}

ATP-binding cassette $(\mathrm{ABC})$ proteins form one of the largest protein families, whose members are found in all organisms, from microorganisms to humans. All ABC proteins contain at least one ATP-binding domain, also known as a nucleotide-binding fold (NBF) that enables them to bind and hydrolyze ATP. The characteristic feature of ABC protein NBFs is the signature motif (LSGGE/Q), localized between the Walker A (GSGKST) and Walker B (DEAT) motifs of the amino acid sequence (Nikaido, 2002). The NBF consists of approximately $90-200$ amino acids and is highly conserved among ABC proteins: the amino acid sequence identity within this region varies from 30 to 50\% (Stefkova et al. 2004, Leslie et al. 2005).

The majority of $\mathrm{ABC}$ proteins are primary active transporters, meaning that they are able to transport substances against their concentration gradients across membrane structures, coupling transport to ATP binding and hydrolysis. Several amino acid residues are known to play an important role in ATP binding: the lysine residue in the Walker A motif is involved in the binding of the $\beta$-phosphate of ATP while the aspartic acid residue in the Walker B motif interacts with $\mathrm{Mg}^{2+}$ (Hung et al. 1998; Sharom et al. 1999). The basic ABC transporter structure comprises conserved ATP-binding and variable transmembrane (TM) domains. The amino acid chain of a TM domain typically forms 6 membrane-spanning $\alpha$-helices (Glavinas et al. 2004). In eukaryotes the functionally active $A B C$ transporters consist of two TM domains and two NBF. When these four domains are present on one polypeptide chain, the transporter is termed a full transporter (fig. 1). ABC transporters containing only one TM and one NBF are termed half transporters. To establish a functional transporter, these proteins form a homo- or heterodimer with another half transporter. Evidence from X-ray structure analysis of $\mathrm{ABC}$ proteins suggests that the $\mathrm{ABC}$ signature motif sequence of one $\mathrm{NBF}$ is adjacent to the Walker $A$ sequence of the opposite NBF in a so-called sandwich configuration (Hopfner and Tainer, 2003; Locher et al. 2002). This configuration appears to be necessary for binding and hydrolysis of ATP (Tombline et al. 2004).

$\mathrm{ABC}$ transporters transport a wide range of compounds across biological membranes (Borst and Oude Elferink, 2002). However, a detected basic ABC transporter structure does not necessarily mean that an active transport will be performed. Some ABC transporters function 
as channels or parts of channel complexes, for example the chloride channel ABCC7/CFTR (Borst and Oude Elferink, 2002) or the ATP-sensing subunits of complex potassium channels (ABCC8 and 9, alias SUR1 and 2, respectively).

TM1

\section{TM2}

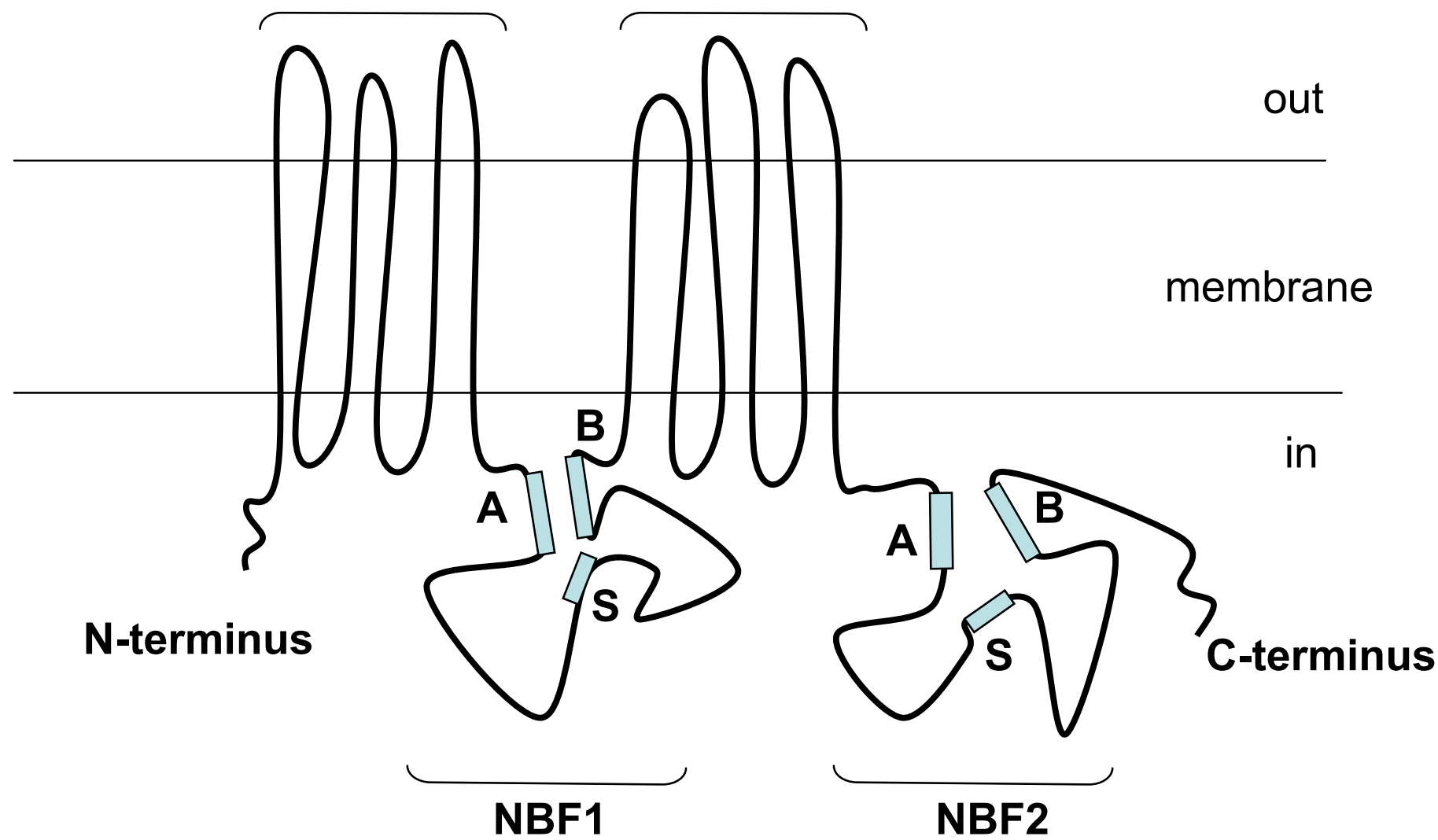

Figure 1. The structure of a typical $\mathbf{A B C}$ full transporter. The full $A B C$ transporter consists of two transmembrane domains, TM1 and TM2, and two nucleotide-binding folds NBF1 and NBF2. Six membrane-spanning $\alpha$-helices are a characteristic feature of TM domains. Walker A (A), Walker B (B) motifs and the ABC protein superfamily signature motif (S) are involved in ATP binding as described in the text. 
$\mathrm{ABC}$ genes are widely dispersed in eukaryotic genomes and are highly conserved among species. According to the nomenclature scheme of the HUGO gene nomenclature committee, the symbols "ABC.." in capital letters refer to human ABC transporters. Symbols "mAbc..", such as mAbcb7, denote mouse forms and "rAbc..", such as rAbcb7, denote rat forms. The mutations detected in human $\mathrm{ABC}$ genes were found to be responsible for various disease phenotypes (cystic fibrosis: ABCC7/CFTR, progressive familial intrahepatic cholestasis: ABCB11, X-linked sideroblastic anemia and ataxia (XLSA/A): ABCB7). Homo sapiens $\mathrm{ABC}$ proteins represent the largest functionally investigated $\mathrm{ABC}$ group among the eukaryotes: 49 human ABC genes have been identified. The alignment of amino acid sequences of the NBF and the phylogenetic analyses performed with a number of methods allowed to group the existing eukaryotic ABC proteins into seven major subfamilies, named alphabetically from A to G.

The ABCA subfamily comprises 12 full transporters (Broccardo et al. 1999). The extensively studied members are involved in translocation of cholesterol and membrane phospholipids (ABCA1) or in transport of vitamin A/phospholipid derivatives (ABCA4) (Dean et al. 2001; Allikmets et al. 1997).

The ABCB (MDR/TAP) subfamily contains 4 full transporters (ABCB1, ABCB4, ABCB5 and $\mathrm{ABCB} 11)$ and 7 half transporters $(\mathrm{ABCB} 2, \mathrm{ABCB} 3$ and $\mathrm{ABCB} 6$ to $\mathrm{ABCB} 10)$. The members of the human $\mathrm{ABCB}$ subfamily exhibit the highest substrate diversity among the ABC subfamilies. $\underline{A B C B 1 / P G P / M D R 1}$ was the first human $\mathrm{ABC}$ transporter characterized through its ability to confer a multi-drug resistance (MDR) phenotype to cancer cells (Juliano and Ling, 1976). ABCB1 mediates extrusion of hydrophobic substrates, lipids, steroids and xenobiotics, including drugs such as colchicine, etoposide (VP16), adriamycin, vinblastine and the cyclic peptide cyclosporine A (Gottesman et al. 2002). ABCB1 also exerts a protective role in the blood-brain barrier (Schinkel et al. 1997). The ABCB2/TAP1 and $\underline{\mathrm{ABCB} 3 / \mathrm{TAP} 2}$ half transporters form a heterodimer and translocate peptides derived mainly from proteasomal degradation of endogenous proteins from the cytosol into the lumen of the endoplasmic reticulum, where these peptides are loaded onto the major histocompatibility complex I (MHC class I) molecules (Abele and Tampé, 2006) to support self tolerance. $\mathrm{ABCB} 4 / \mathrm{MDR} 3 / \mathrm{PGY} 3 / \mathrm{MDR} 2$ is a phosphatidylcholine transporter, whereas the $\mathrm{ABCB} 11 / \mathrm{BSEP} / \mathrm{SPGP}$ full transporter participates in the secretion of bile salts 
(taurocholate) into the bile (Smit et al. 1993; Gerloff et al. 1998). The $\underline{\text { ABCB6/MTABC3}}$, $\underline{\mathrm{ABCB} 7 / \mathrm{ABC} 7}, \underline{\mathrm{ABCB} 8}$ and $\underline{\mathrm{ABCB} 10}$ half transporters have been described to locate to the mitochondria (Allikmets et al. 1996). $\underline{\mathrm{ABCB} 7}$ and $\underline{\mathrm{ABCB} 6}$ are introduced separately. Rat rAbcb1/Pgp/Mdr1 (Lee et al. 1993), rAbcb2/Tap1, rAbcb3/Tap2 (Koopmann et al. 1996), rAbcb4/Mdr3 (Gatmaitan et al. 1997) and rAbcb11/rBsep (Hayashi et al. 2005) transporters were shown to be involved in analogous processes as their human orthologues. Other rat Abcb subfamily members like rAbcb8 (Melaine et al. 2005) or rAbcb7 (more details in the 1.3 chapter of this work) have recently been cloned and their functions remain to be investigated.

The ABCC (CFTR/MRP) subfamily consists of 12 full transporters with diverse functional spectra. $\underline{\mathrm{ABCC} 1 / \mathrm{MRP} 1}$ and $\underline{\mathrm{ABCC} 6 / \mathrm{MRP} 6}$ transport glutathione-linked compounds out of cells (Deeley and Cole, 2006), whereas the ABCC7/CFTR protein is a phosphorylationdependent chloride channel located in the apical membrane of epithelial cells. The $\underline{\mathrm{ABCC} 7 / \mathrm{CFTR}}$ protein has a large hydrophilic domain between the NBF1 and TM2 that is involved in regulation of the activity of the channel (Frelet and Klein, 2006).

The ABCD subfamily contains 4 half transporters located in the peroxisomal membrane. ABCD3/PMP70/PXMP1 mediates long-chain fatty acid (LCFA)-CoA transport, whereas the $\underline{\mathrm{ABCD} 1 / A L D P}$ (adrenoleukodystrophy protein) is involved in the transport of very long chain fatty acids (more than 24 fatty acids/chain), whose accumulation in the cytoplasm leads to neurodegenerative X-linked adrenoleukodystrophy (Theodoulou et al. 2006).

The ABCE (OABP) and ABCF (GCN20) subfamilies contain proteins that have no TM domains. $\underline{A B C E 1 / R N S 4 I}$ protein inhibits the RNase L, a ribonuclease that is activated by interferons (Bisbal et al. 1995). $\underline{\mathrm{ABCF} 1 / \mathrm{ABC} 50}$ is activated by tumor necrosis factor- $\alpha$ (TNF- $\alpha$ ) and putatively participates in translation initiation (Richard et al. 1998, Tyzack et al. 2000).

The ABCG subfamily is composed of "reverse" half transporters that have an NBF at the Nterminus and the TM domain at the C-terminus. $\mathrm{ABCG} 2 / \mathrm{MXR} / \mathrm{BCRP} / \mathrm{ABCP}$ functions as a homodimer and confers resistance to anthracycline anticancer drugs (Ross et al. 1999), whereas $\underline{\mathrm{ABCG} 5}$ forms a heterodimer with $\underline{\mathrm{ABCG} 8}$ and promotes sterol excretion into bile and intestinal lumen (Graf et al. 2003). 


\subsection{Mammalian $\mathrm{ABCB} 6$ and $\mathrm{ABCB} 7$ half transporters}

The $\underline{\mathrm{ABCB} 7 / \mathrm{ABC} 7}$ gene was shown to be ubiquitously expressed and mapped to the Xq12q13 region of the human genome (Savary et al. 1997). The protein sequence was found to be 43\% identical with Saccharomyces cerevisiae Atm1p (Csere et al. 1998). Atm1p plays a role in the maturation of cytosolic Fe/S proteins and in mitochondrial iron homeostasis (Lill and Kispal, 2001). Human ABCB7 was found to be located within mitochondria and to functionally complement defective Atm1p in Saccharomyces cerevisiae (Csere et al. 1998). Allikmets and colleagues showed that ABCB7 was the causal defect gene of the X-linked sideroblastic anemia with ataxia (XLSA/A) syndrome. This disease is characterized by iron accumulation in the mitochondria of bone marrow erythrocyte precursors (Allikmets et al. 1999), indicating that ABCB7 might be involved in iron homeostasis of the cell. Orthologues half transporters exist in rodents. Although murine Abcb7 cDNA had been isolated by Savary et al. 1997, the full coding rat Abcb7 (rAbcb7) cDNA had not been clarified yet at the beginning of this thesis project.

The $\underline{\text { rAbcb6 }}$ cDNA sequence was the first full coding sequence to be detected among the eukaryotic Abcb6 transporters and published by Hirsch-Ernst and co-workers in 1998 (Hirsch-Ernst et al. 1998). rAbcb6 mRNA was found to be ubiquitously expressed in all rat organs, initially leading to the name Umat (ubiquitously-expressed mammalian $\underline{A} B C$ half transporter). Later, the protein was assigned the symbol rAbcb6, in accordance with its homology to human $\mathrm{ABCB} 6$ and the nomenclature scheme of the HUGO gene nomenclature committee. The exceptionally high rAbcb6 mRNA expression in testis (Hirsch-Ernst et al. 1998 ) is likely to be due to its expression in meiotic pachytene spermatocytes and in postmeiotic early spermatids (Melaine et al. 2005). The 2842 bp cDNA encoded a protein with an open reading frame of 836 amino acids (Hirsch-Ernst et al. 1998). The deduced peptide contained a single C-terminal ATP-binding cassette, indicating that the rAbcb6 is a half transporter. The peptide analysis with respect to potential membrane-spanning segments revealed 8 putative membrane-spanning regions in the $\mathrm{N}$-terminal part. Comparison to protein database sequences showed $44.5 \%$ rAbcb6 amino acid identity to the Hmt1 protein of Schizosaccharomyces pombe (Hirsch-Ernst et al. 1998), a half transporter that conferred heavy metal tolerance (Ortiz et al. 1992). A lower amino acid sequence identity, 39\%, was detected between the sequences of rAbcb6 and Atm1p. Due to sequence similarity to Hmt1 and Atm1p, a possible participation of rAbcb6/Umat in biometal homeostasis was suggested 
(Hirsch-Ernst et al. 1998). Indeed, LoVo cells transfected with a rAbcb6/Umat expression plasmid showed an elevated resistance to copper $\left(\mathrm{Cu}^{2+}\right)$ as compared to control-transfected LoVo cells (Hirsch-Ernst et al. 2001). The use of different immunochemical methods indicated that $\mathrm{rAbcb6/Umat} \mathrm{was} \mathrm{localized} \mathrm{to} \mathrm{vesicular} \mathrm{structures,} \mathrm{presumably} \mathrm{lysosomes/late}$ endosomes (Abdul Jalil, 2004). It is expected that the majority of lysosomal membrane proteins contain glycosylated parts, which may protect proteins from degradation within the lysosomal lumina. The digestion of rAbcb6/Umat protein with N-glycosidase $\mathrm{F}$ demonstrated that rAbcb6/Umat was glycosylated (Abdul Jalil, 2004). Mitsuhashi and colleagues published the full coding sequence of human $\mathrm{ABCB} 6 / \mathrm{MTABC} 3$ (Mitsuhashi et al. 2000). The gene was mapped to the $2 q 36$ region of the human genome. ABCB6 and rAbcb6 share 88\% amino acid sequence identity, indicating that ABCB6 is the human orthologue of rAbcb6. Human ABCB6 shares 39\% amino acid sequence identity with the Atm1p of Saccharomyces cerevisiae. Mitsuhashi et al. described human ABCB6 to be located within a mitochondrial membrane and to functionally complement a defect of Atm1p in S. cerevisiae cells (Mitsuhashi et al. 2000). Since both ABCB6 and ABCB7 appeared to functionally complement Atm1p, related functions of $\mathrm{ABCB} 6$ and $\mathrm{ABCB} 7$ have been anticipated.

\subsection{Aims}

Mitsuhashi and colleagues provided evidence that the human ABCB6 was localized to the mitochondria (Mitsuhashi et al. 2000). However, experiments performed by Abdul Jalil (Abdul Jalil, 2004) indicated that rat Abcb6 was associated with vesicular structures (lysosomes/late endosomes). Therefore, one of the aims of this work was to verify the subcellular localization of rat rAbcb6 via co-expression of differentially tagged rAbcb6 with lysosomal and mitochondrial organelle markers in different cell lines (human LoVo and mouse TM3 cells).

The rAbcb6 protein is a half transporter that requires a dimerization partner to be able to perform its function. For the optimization of future functional studies for rAbcb6, it was crucial to detect the Abcb6 half transporter's dimerization partner. In Homo sapiens, the half transporters ABCB6 and ABCB7 share an amino acid sequence identity of about $41 \%$. Both human proteins were shown to functionally complement Atm1p of $S$. cerevisiae. The suggested mitochondrial localization of both $\mathrm{ABCB} 6$ and $\mathrm{ABCB} 7$ and functional 
complementation of the same protein led to the hypothesis that human ABCB6 and ABCB7 might dimerize. Considering the high amino acid sequence identity between human ABCB6 and rat Abcb6 (88\%), the hypothesis was further extended: the heterodimerization partner for rat Abcb6 might be rat Abcb7 protein. The possibility of rat rAbcb6 homodimerization to form a functional full transporter complex was also considered.

The following aims were pursued within the present thesis:

(1) To be able to characterize $\mathrm{rAbcb7}$ as a potential dimerization partner of rAbcb6, the full coding cDNA sequence of rAbcb7, which at the beginning of this project had not yet been identified, was to be cloned.

(2) Since subcellular co-localization was expected to be a prerequisite for substantial dimerization of rAbcb6 and rAbcb7, several approaches showing the expression of half transporter fusion proteins (rAbcb6-EGFP, rAbcb6-V5, rAbcb6-DsRed2, rAbcb7-EGFP, rAbcb7-V5, rAbcb7-DsRed2) in transfected cell lines were to be used to investigate/confirm the subcellular localization of these proteins.

( 3 ) Protein interaction between potential dimerization partners (rAbcb6/rAbcb6), (rAbcb6/rAbcb7) or (rAbcb7/rAbcb7) was to be investigated via co-immunoprecipitation analysis of particular subcellular fractions that showed enrichment of transporter fusion proteins. 


\section{Materials and Methods}

\subsection{Materials}

\subsubsection{Reagents and enzymes}

Reagents not separately listed beneath were purchased in the highest purity degree available from Applichem (Darmstadt), Fluka (Buchs, Switzerland), Merck (Darmstadt), Roche Diagnostics (Mannheim), Sigma (Deisenhofen) or Serva (Heidelberg).

Acrylamide $4 \mathrm{~K}\left(29: 1,30 \%\right.$ in $\left.\mathrm{H}_{2} \mathrm{O}\right)$

Agar

Agarose

Agarose LM

Ampicillin

$\beta$-agarase

Calf intestine alkaline phosphatase (CIAP)

Chloroform

Collagenase CLS II (172 I.U./mg)

Complete Protease Inhibitor

Developer G153

DTT

dNTP's

Ethidium bromide

Non-fat milk powder

Fast Fixer G354

Fetal Calf Serum (FCS)

Folin-Ciocalteus-phenol reagent

Fugene 6

Guanidinium thiocyanate (97\%)

G418

Herring sperm DNA

High Fidelity DNA Polymerase

IPTG

Kanamycin
Applichem

Applichem

Genaxis, Spechbach

Genaxis

Applichem

MBI Fermentas, St. Leon-Rot, Germany

MBI Fermentas

Merck

Biochrom KG, Berlin

Roche

Agfa-Gevaert AG, Mortsel, Belgium

Applichem

MBI Fermentas

Serva

Applichem

Agfa-Gevaert

Cambrex, Apen, Germany

Merck

Roche Diagnostics

Fluka

Genaxis

Roche

Invitrogen, Karlsruhe

Applichem

Applichem 
$\beta$-Mercaptoethanol

MOPS

Penicillin/Streptomycin, A2213

(10 $000 \mathrm{U} / 10000 \mu \mathrm{g} / \mathrm{ml})$

Phenol

Ponceau S

$\left[\gamma_{-}{ }^{32} \mathrm{P}\right]$-dATP (activity in $222 \mathrm{TBq} / \mathrm{mmol}$ )

Proteinase K, S3004, S3040

Restriction enzymes

RNAse A

RNAse Block

SDS

Superscript ${ }^{\mathrm{TM}}$ II reverse transcriptase

Taq polymerase

Titriplex III (EDTA)

Tris

Tri-sodium citrate

Trypsin/EDTA

Tryptone

Tween 20

X-gal

Yeast extract
Merck

Sigma

Biochrom

Roth, Karlsruhe

Sigma

PerkinElmer, Wellesley (MA, USA)

DAKO, Hamburg

MBI Fermentas

New England Biolabs, Beverly (MA, USA)

MBI Fermentas

Stratagene, La Jolla (CA, USA)

Sigma

Invitrogen

Peqlab, Erlangen

Merck

Merck

Merck

Biochrom

Applichem

Sigma

Applichem

Applichem

\subsubsection{Kits}

Big Dye Terminator v1.1 Cycle Sequencing Kit Endo Free Plasmid Maxi Kit

Superscript $^{\mathrm{TM}}$ III One-Step RT-PCR Kit

Titan One Tube RT-PCR Kit pcDNA3.1/V5-His TOPO Cloning Kit
Applied Biosystems, Weiterstadt Qiagen, Hilden Invitrogen

Roche

Invitrogen 
QIAquick Gel Extraction Kit

5'/3' RACE PCR Kit

Super Signal West Pico Kit

TOPO-XL Cloning Kit

TOP 10 electro-competent cells

\subsubsection{Expendable supplies}

Culture flasks $175 \mathrm{~cm}^{2}, 75 \mathrm{~cm}^{2}$

Culture plates $58 \mathrm{~cm}^{2}, 21 \mathrm{~cm}^{2}$

Electroporation cuvettes, $2 \mathrm{~mm}$

Eppendorf UV-cuvettes, 50-1000 $\mu 1$

Falcon $15 \mathrm{ml}$ tubes

Filter cartouche Sartolab-P-plus $(0.2 \mu \mathrm{m})$

Filter paper: thin (2043) and thick (2668)

Half-micro-plastic cuvettes $1.6 \mathrm{ml}$

Hyperfilm-ECL

Freezing tubes $1.8 \mathrm{ml}$

Needles

Plastic pipettes: $1 \mathrm{ml}, 2 \mathrm{ml} 10 \mathrm{ml}, 20 \mathrm{ml}$

Multiwell plates, 6 wells of $9.6 \mathrm{~cm}^{2}$

PCR tubes $0.2 \mathrm{ml}$

Polaroid-667 films

PP-tubes: $13 \mathrm{ml}, 15 \mathrm{ml}$

Gel Saver II pipette tips

Sephadex Micro Spin columns G-25

Syringe filters: $0.2 \mu \mathrm{m}, 0.45 \mu \mathrm{m}$

Syringes: $1 \mathrm{ml}, 2 \mathrm{ml}, 5 \mathrm{ml}, 10 \mathrm{ml}, 50 \mathrm{ml}$

Vacuum filters: $125 \mathrm{ml}, 0.2 \mu \mathrm{m}, 0.45 \mu \mathrm{m}$
Qiagen

Roche

Pierse Biotechnology, Rockford (IL, USA)

Invitrogen

Invitrogen

Sarstedt, Nuembrecht, Germany

Nunc, Kampstrup, Denmark

Sarstedt

Peqlab, Erlangen

Eppendorf

Schuett, Goettingen

Sartorius

Schleicher u. Schuell

Sarstedt

Amersham

Nunc

Braun, Melsungen

Greiner, Nuertingen

Nunc

Abgene, Epsom (GB)

Sigma

Sarstedt

Gerlinde Kisker, Muehlhausen

Pharmacia Biotech, Freiburg

Schleicher u. Schuell

Braun

Schleicher u. Schuell 


\subsubsection{Equipment}

\subsubsection{Cell culture equipment}

Vertical autoclave FV

Steri-Cult 303 incubator

C200 incubator

Chilling centrifuge 5810R with

Inverse microscope: ID 02

Perfusion pump Masterflex 7013.21

Sterile flow hood Biograd Hood B40-112

Sterile flow hood SterilGard III Advance

Flexible-tube pump PML 1305-ND100 for sterile filtration KNF Flodos/ Sartorius

Table centrifuge Rotanta/P

Fuchs-Rosenthal cell counting chamber: Bright line

(0.2 $\mathrm{mm}$ deep, $0.0625 \mathrm{~mm}^{2}$ )
Hettich, Tuttlingen

Karl-Hecht-Assistant,

Sonderheim/ Roehn
Technomara, Fernwald

Forma Scientific, Marietta (USA)

Labotech, Goettingen

Eppendorf, Hamburg

Zeiss, Goettingen

Cole-Parmer (Chicago, USA)

Baker, Sanford (MN, USA)

Labotect, Goettingen

\subsubsection{Molecular biology devices}

$\begin{array}{lll}\text { Electroporator } & \text { Gene Pulser II } & \text { Bio-Rad } \\ \text { Incubator } & \text { Dry incubator MIR-153 } & \text { Sanyo/Krannich } \\ \text { Shaker } & \text { Vibramax 100 } & \text { Heidolph, Kehlheim } \\ \text { Sequencer } & 3100 \text { Genetic Analyzer } & \text { ABI } \\ \text { Software } & \text { Staden Package } & \text { Perkin Elmer } \\ & \text { Clustal W } & \text { EBI } \\ & \text { Chromas } & \text { Technelysium } \\ & \text { BLAST } & \text { NCBI } \\ \text { Thermocycler } & \text { Gradient Mastercycle } & \text { Eppendorf } \\ & \text { Thermo block UNO } & \text { Biometra, Goettingen } \\ \text { Vacuum centrifuge } & \text { Concentrator 5301 } & \text { Eppendorf } \\ & \text { with membrane vacuum pump } & \text { Vacuubrand, Wertheim }\end{array}$




\subsubsection{Appliances for DNA and RNA analyses}

Electrophoresis: horizontal gel chamber: H5

Horizon 11-14 and Horizon 20-25

Hybridization glass tube $15 \times 3.5 \mathrm{~cm}$

Hybridization oven OV5

Polaroid DS-34 camera with fading and orange filters

Quartz cuvettes: $1 \mathrm{ml}$

Nylon membrane Hybond-N; $0.45 \mu \mathrm{m}$

$\left[{ }^{32} \mathrm{P}\right]$-detector Bio-Imaging-Analyzer Bas 1500

${ }^{32} \mathrm{P}$ sensitive imaging plates, 2040 and Fujix cassettes

${ }^{32} \mathrm{P}$ radiation evaluation software:

Bas-reader 2.9, TINA 2.0

Biophotometer 6313

Power supply unit Phero-Stab 330

GFL 1083 shaker (water bath)

Ray surface detector $(\beta / \gamma) 122$

UV-transilluminator TI2

UV-cross linker Bio-Link
Gibco/BRL, Eggenstein

Biometra

Biometra

Biometra

Sigma

Hellma, Krannich

Amersham

Fujix, Tokyo

Fujix, Tokyo

Fujix, Tokyo

Eppendorf

Biotech-Fischer, Reiskirchen

Schuett

Berthold, Pforzheim

Biometra

Biometra

\subsubsection{Equipment for protein analyses}

Gel casting system for electrophoresis:

Mighty Small SE245 Dual Gel Caster and

Mighty Small II vertical electrophoresis chamber

Stir motor RW12 for homogenization

Hoefer, San Francisco (USA)

Glass/teflon homogenization tools

Janke \& Kunkel, Staufen

Fluorescence microscope

Braun

PVDF-membrane Immobilon-P; $0.45 \mu \mathrm{m}$

Zeiss, Goettingen

Millipore, Eschborn

Power supply unit Standard Power Pack P25

Biometra

Semi-dry transfer chamber with glass/graphite- 
and stainless steel electrode

Ultrasonic bath Sonorex RK 106

L8-70M ultracentrifuge with SW50.1 rotor

$\mathrm{J} 2-21 \mathrm{M} / \mathrm{E}$ chilling centrifuge 5810R with JA 20 rotor

Rotanta/P table centrifuge

Chilling centrifuge $22 \mathrm{R}$
Phase, Luebeck

Bandelin, Berlin

Beckman, Krefeld

Beckman

Hettich, Tuttlingen

Hettich

\subsubsection{Experimental animals, cultured cells and bacteria}

\subsubsection{Laboratory animals}

Primary rat hepatocytes were isolated from male Wistar rats (Rattus norvegicus L.) with 180 - 240 g body weight. The rats were obtained from the central facility for experimental animals of the University Goettingen, where the animals were kept under constant conditions with light-dark periods changing every 12 hours, fed with standard food (Altrumin Standard, Nr. 13324, Lage, Lippe) and water ad libitum.

\subsubsection{Eukaryotic cell lines}

The LoVo cell line was purchased from the German Collection of Microorganisms and Cell Cultures GmbH (Deutsche Sammlung von Mikroorganismen und Zellkulturen, DSMZ). The HEK293 cell line was donated by colleagues from the Department of Clinical Pharmacology, University of Goettingen. The TM3 cell line was purchased from ECACC (The European collection of cell cultures), distributed by Sigma (Deisenhofen, Germany).

\begin{tabular}{lll}
\hline Cell line & Description & Author \\
\hline & & \\
HEK293 & human embryonic kidney cell line & Graham et al. (1980) \\
TM3 & mouse Leydig cell line, testis & Mather JP (1980) \\
LoVo & human adenocarcinoma & Drewinko et al. (1976) \\
\hline
\end{tabular}




\subsubsection{Primary rat hepatocytes}

Rat hepatocytes, provided by other members of the group and used for cell culture experiments, were prepared as described by Ziemann, 1998. The hepatocytes were isolated from the rat liver by in situ collagenase perfusion according to modification of methods described by Berry and Friend (1969) and Seglen (1976). In brief, following pre-perfusion and digestion with collagenase in situ, the rat liver was removed and hepatocytes released by opening the liver capsule. Hepatocytes were separated from connective tissue, capsule components and non-parenchymal cells by centrifugation and subjecting the suspension to filtration. The cell density and viability were determined with a Fuchs-Rosenthal counting chamber and applying the trypan blue exclusion test. The test involving the post-vitality dye trypan blue was performed as follows. The hepatocyte cell suspension was diluted 1:100 and stained with an equal volume of $0.5 \%$ trypan blue solution. Hepatocytes used for cultivation exhibited a viability of at least $90 \%$.

\subsubsection{Bacteria}

The electro-competent Escherichia coli strain TOP 10 was used for transformation experiments. The stock of TOP 10 bacteria was purchased from Invitrogen. Further electrocompetent E. coli were produced as described in chapter 2.2.6.3. 


\subsubsection{Culture media for electro-competent E.coli bacteria}

\begin{tabular}{llll}
\hline & SOC medium & LB medium & LB agar medium \\
\hline Tryptone & $2.0 \%(\mathrm{w} / \mathrm{v})$ & $1.0 \%(\mathrm{w} / \mathrm{v})$ & $1.0 \%(\mathrm{w} / \mathrm{v})$ \\
Yeast extract & $0.5 \%(\mathrm{w} / \mathrm{v})$ & $0.5 \%(\mathrm{w} / \mathrm{v})$ & $0.5 \%(\mathrm{w} / \mathrm{v})$ \\
$\mathrm{NaCl}$ & $0.06 \%(\mathrm{w} / \mathrm{v})$ & $1.0 \%(\mathrm{w} / \mathrm{v})$ & $1.0 \%(\mathrm{w} / \mathrm{v})$ \\
$\mathrm{KCl}$ & $2 \mathrm{mM}$ & - & - \\
$\mathrm{MgCl}_{2}$ & $10 \mathrm{mM}$ & - & - \\
$\mathrm{MgSO}_{4}$ & $10 \mathrm{mM}$ & - & - \\
$\mathrm{Glucose}$ & $20 \mathrm{mM}$ & - & - \\
$\mathrm{Agar}$ & - & - & $1.5 \%(\mathrm{w} / \mathrm{v})$ \\
$\mathrm{pH}$ & 7.0 & 7.0 & 7.0 \\
\hline
\end{tabular}

Media were prepared by dissolving reagents listed above in bidistilled water and autoclaving. The required amount of glucose was dissolved in autoclaved bidistilled water, subjected to sterile filtration and then added to the autoclaved medium. SOC medium was stored at $-20^{\circ} \mathrm{C}$ and thawed before use. LB medium was stored at $4{ }^{\circ} \mathrm{C}$ up to several months. For the preparation of LB agar plates the autoclaved agar-containing LB medium was cooled to $55^{\circ} \mathrm{C}$ prior to the addition of antibiotic. The final concentration of ampicillin was $0.1 \mathrm{mg} / \mathrm{ml}$ and of kanamycin $0.05 \mathrm{mg} / \mathrm{ml}$. If required, IPTG and X-gal (final concentrations were 80 $\mathrm{mg} / \mathrm{l}$ for X-gal and $100 \mu \mathrm{M}$ for IPTG in the medium) were added to the agar medium before pouring it into $58 \mathrm{~cm}^{2}$ plastic culture plates. After the LB agar medium had solidified, the plates were inverted and stored at $4{ }^{\circ} \mathrm{C}$ in the dark. Depending on the antibiotic used, LB agar plates maintained their selectivity for up to six months (kanamycin) or only for two weeks (ampicillin) at $4^{\circ} \mathrm{C}$. 
Stock solutions used for media of bacteria

$$
\begin{aligned}
& 50 \mathrm{mg} / \mathrm{ml} \text { ampicillin in } \mathrm{H}_{2} \mathrm{O} \\
& 50 \mathrm{mg} / \mathrm{ml} \text { kanamycin in } \mathrm{H}_{2} \mathrm{O} \\
& 100 \mathrm{mM} \text { IPTG in } \mathrm{H}_{2} \mathrm{O} \\
& 40 \mathrm{mg} / \mathrm{ml} \mathrm{X-gal} \mathrm{in} \mathrm{DMF}
\end{aligned}
$$

Stock solutions of antibiotics, IPTG and X-gal were subjected to sterile filtration and stored at $-20^{\circ} \mathrm{C}$ for up to 9 months.

\subsubsection{Cell culture media}

\subsection{Eukaryotic cell line media}

Liquid media were ordered from Gibco and Biochrom AG (Berlin). Before use media were supplemented by addition of $10 \%$ (v/v) FCS, 50,000 U/50,000 $\mu \mathrm{g}$ of penicillin/streptomycin and, if required, $5 \mathrm{ml}$ of $200 \mathrm{mM} \mathrm{L}$-glutamine solution per $500 \mathrm{ml}$ of media. L-glutamine was purchased from Invitrogen (100 x concentrated as a $200 \mathrm{mM}$ solution), aliquoted and stored at $-20^{\circ} \mathrm{C}$. The antibiotics mixture was bought from Biochrom AG as a solution containing $10,000 \mathrm{U} / 10,000 \mu \mathrm{g} / \mathrm{ml}$ of penicillin/streptomycin, respectively. The FCS was purchased from Cambrex. 


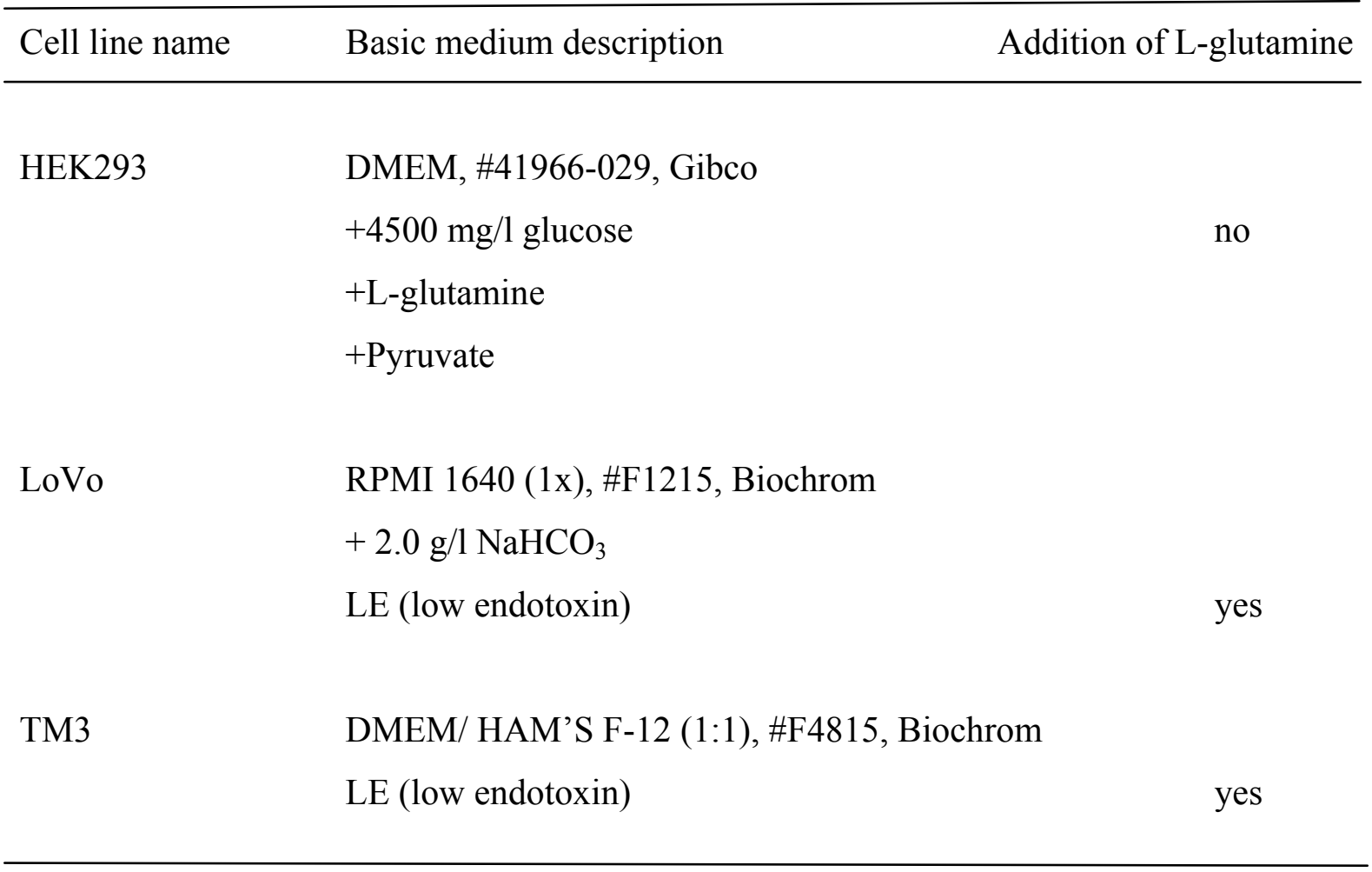

For long-time storage of eukaryotic cell stocks in liquid nitrogen the amount of FCS was raised to $20 \%$ and DMSO was added to a final concentration of $10 \%$ to the appropriate medium.

\subsection{Primary rat hepatocyte culture media}

For cultivation of primary rat hepatocytes media were prepared from separate components as follows:

MX-82 according to Hoffmann et al. (1989) was used as the basal medium for the preparation of MX-83 medium and MX-82 containing 10\% of FCS was used as cell adhesion medium for the first 3 hours of hepatocyte cultivation. MX-82 is a modified DMEM (Dulbecco's Modified Eagle's Medium, Smith et al. 1960) that contained penicillin G (15 $\mu \mathrm{g} / \mathrm{l})$ and streptomycin sulfate $(31.5 \mu \mathrm{g} / \mathrm{l})$. The buffering was adjusted to $10 \% \mathrm{CO}_{2}$ of cell culture atmosphere. The two-fold concentrated basal medium was prepared from separate 
components, aerated with $\mathrm{CO}_{2}$ for 1 hour and subjected to sterile filtration through SartolabP-plus filter column $(0.2 \mu \mathrm{m})$. MX-82 was stored for several months at $4{ }^{\circ} \mathrm{C}$.

$\underline{\text { MX-83 }}$ contained MX-82 as the basal medium and was supplemented with vitamins, lipids, trace elements, metabolites and transferrin $(10 \mathrm{nM})$. In MX-83 medium the amino acid arginine was replaced by ornithine $(67.4 \mathrm{mg} / \mathrm{ml})$ to inhibit the growth of other cell types, that might have been isolated together with rat hepatocytes from rat liver, since the urea cycle represents a metabolic function specific for hepatocytes. Only hepatocytes can produce arginine by converting ornithine in the urea cycle. The presence of mevalonic acid in the MX-83 is a deviation from the medium content, described by Hoffmann et al. (1989). For the maintenance of differentiated cell functions and for better cell adhesion to substrate, $1 \mu \mathrm{M}$ bovine insulin (stock solution: $100 \mu \mathrm{M}$ in $0.1 \mathrm{M} \mathrm{HCl} / 0.1 \% \mathrm{BSA}$ ) and $20 \mu \mathrm{M}$ hydrocortisone hemisuccinate (stock solution: $2 \mathrm{mM}$ in sterile bidistilled water) were added to the serumfree MX-83. All stock solutions required for MX-83 were stored at $-20^{\circ} \mathrm{C}$. The MX-83 was prepared shortly before use and stored at $4{ }^{\circ} \mathrm{C}$ for a few days only.

\subsection{Cell mounting media}

To preserve fluorescence after cell fixation and immunofluorescence applications two types of mounting media from Vector Laboratories (Burlingame, CA, USA) were used: VECTASHIELD ${ }^{\circledR}$ Mounting Medium and VECTASHIELD ${ }^{\circledR}$ Mounting Medium with DAPI. DAPI colored cell nuclei in violet $(350 \mathrm{~nm})$ by interacting with DNA. 


\subsubsection{Vectors, antibodies and oligonucleotides}

\subsubsection{Vectors}

The following vectors were used to make cDNA of genes available for sequencing or to gain desired fusion proteins:

$\begin{array}{ll}\text { pCR }{ }^{\circ}-\mathrm{XL}-\mathrm{TOPO} & \text { Invitrogen } \\ \text { pcDNA3.1/V5-His TOPO } & \text { Invitrogen } \\ \text { pEGFP-N1 } & \text { BD Biosciences } \\ \text { pDsRed2-N1 } & \text { BD Biosciences }\end{array}$

\subsubsection{Antibodies}

For immunofluorescence, a FITC-conjugated mouse monoclonal antibody against the V5 epitope (Invitrogen) was used.

Antibodies used for immunoprecipitation:

- mouse monoclonal $\mathrm{IgG}_{2 \mathrm{a}}$ antibody against V5 (Invitrogen).

- polyclonal antibody against full-length GFP (green fluorescence protein, BD Biosciences) raised in rabbit, cross-reacting with the EGFP (enhanced green fluorescent protein).

- pre-immune serum: serum obtained from rabbit prior to immunization with a rat Abcb6 (rAbcb6) peptide. 
For Western blot the following antibodies were used:

Primary antibodies

Secondary antibodies

Affinity-purified mouse $\operatorname{IgG}_{2 a}$

Anti-mouse peroxidase conjugated

monoclonal anti-GFP (BD Biosciences)

polyclonal IgG raised in rabbit (Sigma)

(cross-reacting with EGFP)

Anti-V5-horseradish-peroxidase (HRP)

conjugated mouse monoclonal $\operatorname{IgG}_{2 \mathrm{a}}$ (Invitrogen)

Rabbit IgG polyclonal against the

Anti-rabbit peroxidase conjugated

full-length GFP (BD Biosciences)

polyclonal IgG raised in goat (Sigma)

(cross-reacting with EGFP)

\subsubsection{Oligonucleotides}

Oligonucleotides were ordered from IBA (Goettingen, Germany) as $100 \mu \mathrm{M}$ stock solutions or from Sigma-Genosys-ARK (Munich, Germany) as lyophilized powder that was set up to $100 \mu \mathrm{M}$ with the indicated volume of autoclaved water. The oligonucleotide stocks were stored at $-20^{\circ} \mathrm{C}$.

Sequences of oligonucleotides displayed in the following tables are in the orientation of synthesis (5'-end to 3'-end). 
Table 1. Oligonucleotides used as forward and reverse primers for re-cloning and sequencing of $\mathrm{rAbcb6} \mathrm{cDNA}$ from primary rat hepatocytes.

\begin{tabular}{lll}
\hline \multicolumn{3}{c}{ rAbcb6 re-cloning and sequencing primers } \\
\hline Sense primer & 5' to 3' sequence & application \\
\hline B6F1 & GACCTCAAGTTCAACCAGCA & re-cloning \\
B6F2 & GTCTGGATGAAGTTCAGGCA & sequencing \\
B6F3 & CCGTTACCACCTATGTCTTCCT & sequencing \\
B6F4 & GAACGCTATCGAGAGGCCAT & sequencing \\
B6F5 & GTCCTTCACTGTGATGCCT & sequencing \\
B6F6 & AGTGACCTCAAGTTCAACCAG & re-cloning \\
& & \\
\hline Anti-sense primer & 5' to 3' sequence & re-cloning \\
\hline & & detection \\
B6R1 & GAGAGTCTTCAGGGACAGTTTC & re-cloning \\
B6R3 & TCCACAATCCGAAGCACC & \\
\hline
\end{tabular}


Table 2. Oligonucleotides used as forward and reverse primers for cloning and sequencing of Abcb7 cDNA from primary rat hepatocytes.

\begin{tabular}{lll}
\hline Sense primer & 5' to 3' sequence & application \\
\hline B7F1 & CTGGACTTCATGATGCAATTC & cloning \\
B7F2 & GCTCGCGATACATTCTTG & cloning \\
B7F3 & TCTTATGTGTGGCCCAAAGA & sequencing \\
B7F4 & TCTGATTGGCTATGGTGTATC & sequencing \\
B7F5 & AGTCCTTAGCGGAGTATCTT & sequencing \\
B7F6 & GCTCAAGATGGCGCTGC & cloning/sequencing \\
& & \\
\hline Anti-sense primer & 5' to 3' sequence & application \\
\hline & & \\
B7R1 & GATTAAAGGAATGGGAATGTATG & cloning \\
B7R2 & CCTGTCTTTGGGCCACACAT & sequencing/RACE-PCR \\
B7R3 & GGTGCATCACTCAGGTTCA & sequencing \\
B7R4 & TACTCCCACTGCACGCCGAAGAC & sequencing/RACE-PCR \\
B7R5 & GACTGCATATACTTCCTCTG & sequencing \\
B7R6 & CGCAGGAGCAATTTCCACA & cloning \\
\hline
\end{tabular}

For cloning of rAbcb6 and rAbcb7 from one vector to another oligonucleotides containing enzyme restriction sites were designed (tabl. 3). 
Table 3. Oligonucleotides, containing restriction sites or positioned prior to restriction sites necessary for cloning of rAbcb6 and rAbcb7 from one vector into another, were used as sense or anti-sense primers.

\begin{tabular}{llll}
\hline Definition & \multicolumn{1}{c}{ 5' to 3' sequence } & enzyme & cDNA \\
\hline \multirow{2}{*}{ Sense } & GACCTCAAGTTCAACCAGCTAGCAC & NheI & rAbcb6 \\
Anti-sense & CGACCTTAAGTCGACAGAGAGTCTTC & SalI & rAbcb6 \\
Anti-sense & GAATTCGCCTCGAGCAGGAGC & XhoI & rAbcb7 \\
Sense & GCGCTACCGGACTCAGATCTCG & HindIII* & rAbcb7 \\
\hline
\end{tabular}

* - the primer was designed for the nucleotide sequence shortly before (5 bp) the HindIII restriction site on the pDsRed2-N1 vector.

Table 4. Oligonucleotides designed for mRNA detection in Northern blot applications. $\beta$-actin and GAPDH probes were used for control hybridization of Northern blots.

\begin{tabular}{lll}
\hline Probe & 5' to 3'-end sequence & $\begin{array}{l}\text { hybridization to } \\
\text { mRNA of gene }\end{array}$ \\
\hline & & rAbcb6 \\
B6Z1 & GCTGCACCCGGATCCACAGGAAGG & rAbcb7 \\
B7Z1 & CTCCACCGCAGGCCTGAGCCGCAG & rat $\beta$-actin \\
GAPDH & CACTTCCTGTAACCATCTATGCCGTG & rat GAPDH \\
\hline
\end{tabular}

To characterize the human LoVo and HEK293 cell lines concerning the expression of human ABCB6 and ABCB7, oligonucleotides were ordered for use in RT-PCR as mRNA-specific primers. Sequences of these oligonucleotides are displayed in table 5. 
Table 5. Primers for human ABCB6 and ABCB7 cDNA.

\begin{tabular}{lll}
\hline Definition & 5' to 3' sequence & mRNA specificity \\
\hline & & \\
Anti-sense & GGCACGAACAGTTTCCACA & ABCB7 \\
Sense & CAGCGGCTACGTGAGCCA & ABCB6 \\
Anti-sense & GCCGTTCCATGGTCTGAGGCTTA & ABCB6 \\
\hline
\end{tabular}

The sequence at the beginning of the human ABCB7 gene coding part was the same as the one in rat Abcb7 cDNA. Therefore, the B7F6 primer was used as a sense primer for ABCB7 RT-PCR (table 2.).

\subsubsection{Molecular weight standards}

DNA markers:

$1 \mathrm{~kb}$ ladder $1 \mu \mathrm{g} / \mu \mathrm{l}(0.12-12.2 \mathrm{~kb})$

$10 \mathrm{~kb}$ HyperLadder $144 \mathrm{ng} / \mu \mathrm{l}(0.02-10 \mathrm{~kb})$

1.5 kb FastRuler ${ }^{\mathrm{TM}}$ Low Range $4 \mathrm{ng} / \mu \mathrm{l}(0.05-1.5 \mathrm{~kb})$

10 kb FastRuler ${ }^{\mathrm{TM}}$ High Range $4 \mathrm{ng} / \mu \mathrm{l}(0.5-10 \mathrm{~kb})$
Invitrogen

Bioline, Luckenwalde

MBI Fermentas

MBI Fermentas

SDS protein standards:

High Molecular Weight Range (29-205 kDa)

Sigma

Color Burst Electrophoresis Marker (8-220 kDa)

Sigma 


\subsection{Methods}

\subsubsection{Pretreatment and sterilization}

All tools predestinated for use in RNA isolation and Northern blot analysis were incubated in $50 \mathrm{mM} \mathrm{NaOH}$ solution for $20 \mathrm{~min}$ in order to inactivate RNAses.

Heat resistant solutions, glass and plastic materials were sterilized by autoclaving for $25 \mathrm{~min}$ at $121^{\circ} \mathrm{C}$. Non heat resistant solutions were sterilized by filtration (filter pore size $0.2 \mu \mathrm{m}$ ).

\subsubsection{Isolation of nucleic acids}

\subsubsection{Mini-preparation of plasmid DNA}

Buffers required for mini-preparation of plasmid DNA:

Resuspension buffer ( $\mathrm{pH} 8.0)$

$50 \mathrm{mM}$ Tris

10 mM EDTA

$0.1 \%$ RNAse A

Lysis buffer

$200 \mathrm{mM} \mathrm{NaOH}$

$1 \%$ SDS

Neutralization buffer ( $\mathrm{pH} 5.5)$

$3 \mathrm{M}$ potassium acetate

Mini-cultures of $E$. coli bearing a plasmid of interest were received by transferring an E. coli colony from the agar plate to $5 \mathrm{ml}$ LB-medium supplied with a proper antibiotic for selection. The culture was shaken at $750-900 \mathrm{rpm}, 37^{\circ} \mathrm{C}$ for $8-12 \mathrm{~h}$. The isolation of plasmid DNA from culture was performed according to a modification of the alkaline lysis method (Birnboim and Doly, 1979). Two $\mathrm{ml}$ of the mini-culture were centrifuged for $10 \mathrm{~min}$ at $1780 \mathrm{xg}, 4^{\circ} \mathrm{C}$. The pellet was resuspended in $100 \mu \mathrm{l}$ RAse A-containing resuspension buffer, incubated for 5 min with $200 \mu$ alkaline lysis buffer and then for another 5 min with $150 \mu \mathrm{l}$ neutralization buffer. Protein precipitate and cell debris were sedimented by 
centrifugation at $21910 \mathrm{x} \mathrm{g}, 4^{\circ} \mathrm{C}$ for $30 \mathrm{~min}$. The supernatant was transferred into a new 1.5 $\mathrm{ml}$ Eppendof cup, carefully mixed with 2 volumes of $100 \%$ ethanol $(1 \mathrm{ml})$ and centrifuged at

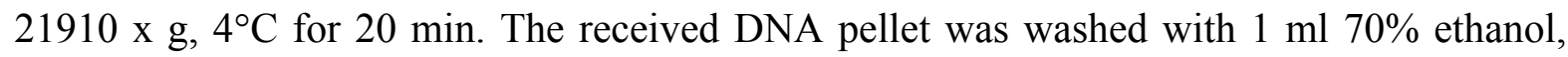
centrifuged at $21910 \mathrm{x} \mathrm{g}, 4^{\circ} \mathrm{C}$, for $5 \mathrm{~min}$, dried in the vacuum centrifuge at $\mathrm{RT}$ and dissolved in 15-20 $\mu 1$ autoclaved bidistilled water. The obtained plasmid DNA was used for restriction analyses, sequencing or eukaryotic cell transfection.

\subsubsection{Preparation of $E$. coli stocks}

E. coli stocks were made from mini-cultures (chapter 2.2.2.1) by pipetting up and down 300 $\mu \mathrm{l}$ of $80 \%$ glycerol together with $300 \mu \mathrm{E}$. coli suspension. This mixture was immediately transferred to $-20^{\circ} \mathrm{C}$ and after $24 \mathrm{~h}$ to $-80^{\circ} \mathrm{C}$.

\subsubsection{Endotoxine-free maxi-preparation of plasmid DNA}

Due to the need of a larger amount of plasmids for transfection of eukaryotic cells, plasmids were isolated using a maxi-prep kit (Endo-Free Plasmid Maxi Kit, Qiagen). For the starter culture approximately $20 \mu \mathrm{l}$ of bacteria from the plasmid carrying E. coli stock were inoculated into $5 \mathrm{ml}$ of LB medium containing the appropriate antibiotic and incubated for approximately $8 \mathrm{~h}$ at $37^{\circ} \mathrm{C}$ with shaking. $150 \mathrm{ml}$ of $\mathrm{LB}$ medium containing the appropriate antibiotic were inoculated with $150 \mu \mathrm{l}$ of the starter culture and grown at $37^{\circ} \mathrm{C}$ for $12-16 \mathrm{~h}$ with vigorous shaking. The over-night $E$. coli culture was centrifuged at $3220 \mathrm{x} \mathrm{g}$ for $20 \mathrm{~min}$, $4^{\circ} \mathrm{C}(5810 \mathrm{R}$, Eppendorf) and lysed according to the protocol present in the kit. Neutralization of the lysis reagent yielded a precipitate containing genomic DNA, proteins and salt complexes. The mixture was applied to the QIAfilter Maxi Cartridge. The flow-through containing the plasmid DNA was further purified through an equilibrated anion exchanging silica column, QIAGEN-tip 500. The purified DNA was eluted, mixed with 0.7 volume of isopropanol and centrifuged at $17000 \times \mathrm{g}(\mathrm{J} 2-21 \mathrm{M} / \mathrm{E}$ centrifuge $)$, at $4^{\circ} \mathrm{C}$ for $30 \mathrm{~min}$. The received pellet was washed with $70 \%$ ethanol, centrifuged at $17000 \mathrm{x}$ g at $4^{\circ} \mathrm{C}$ for $20 \mathrm{~min}$, dried in open air and dissolved in $30-80 \mu 1$ of endotoxin-free TE buffer (Qiagen). For DNA concentration measurements 1:1000 DNA dilutions in bidistilled autoclaved water were used. The plasmid DNA was frozen at $-20^{\circ} \mathrm{C}$. 


\subsubsection{Isolation of total cellular RNA}

Due to different applications of RNA (RT-PCR, Northern blot) and sources (cell line or rat organ) different methods were used for isolation of total cellular RNA: the RNeasy Mini Kit (Qiagen), isolation using TRIzol ${ }^{\mathrm{TM}}$ reagent and a modification of the method described by Chomczynski and Sacchi (1987).

\subsection{RNA isolation according to Chomezynski and Sacchi}

The GTC solution was used to disrupt cells for RNA isolation from cultured mammalian cells and rat organs according to Chomczynski and Sacchi.

$\begin{array}{lll}\text { GTC solution: } & 4 \mathrm{M} & \text { GTC } \\ 17 \mathrm{mM} & \text { sarcosyl } \\ 25 \mathrm{mM} & \text { tri-sodium citrate } \\ 0.1 \mathrm{M} & \beta \text {-mercaptoethanol }\end{array}$

GTC, sarcosyl (N-dodecanoyl-N-methylglycine, sodium salt) and tri-sodium citrate were dissolved in autoclaved bidistilled water at $50^{\circ} \mathrm{C}$. The $\mathrm{pH}$ was adjusted at room temperature to 7.5 and the solution was subjected to filtration through a $0.45 \mu \mathrm{m}$ pore size filter. The solution could be stored at $4^{\circ} \mathrm{C}$ for up to three months. Before usage, $1 \%$ of $\beta$ mercaptoethanol was added to the solution.

\subsection{RNA isolation from cultured mammalian cells}

Five $\times 10^{6}$ to $1 \times 10^{7}$ cells (two $58 \mathrm{~cm}^{2}$ culture plates) per sample were used for RNA extraction. Following culture, cells were washed with PBS and the culture plates shock frozen in liquid nitrogen. One ml of GTC solution was applied per frozen cell plate. Lysed cellular material was scraped from the plates with a rubber policeman and transferred into 13 $\mathrm{ml}$ polypropylene centrifuge tubes. Both plates were additionally washed with $0.5 \mathrm{ml}$ of GTC solution in order to reduce the material loss to a minimum. At the end, the volume of 
GTC solution amounted to $3 \mathrm{ml}$ per sample. $0.3 \mathrm{ml}$ sodium acetate solution ( $\mathrm{pH} 4.0)$ were added to the cell-GTC solution suspension and gently mixed by inverting the tube. The addition of $3 \mathrm{ml}$ phenol (water saturated, $\mathrm{pH} 4.0$ ) was followed by the addition of $0.6 \mathrm{ml}$ chloroform isoamyl alcohol (49:1) solution to the sample. The mixture was shaken vigorously and left on ice until two phases appeared (10 - $30 \mathrm{~min})$. The centrifugation of the sample at $7740 \mathrm{x} \mathrm{g}$ for $20 \mathrm{~min}$ at $4{ }^{\circ} \mathrm{C}$ in the JA 20 rotor resulted in focussing of a protein precipitate between the two phases. The upper, RNA containing phase was transferred into a new tube, mixed with $3 \mathrm{ml}$ isopropyl alcohol and kept at $-20^{\circ} \mathrm{C}$ for at least $3 \mathrm{~h}$. The centrifugation of the sample at $15,000 \mathrm{x} \mathrm{g}$ and $4{ }^{\circ} \mathrm{C}$ for $30 \mathrm{~min}$ yielded a pellet that was dissolved in $1.5 \mathrm{ml}$ GTC solution. After addition of $1.5 \mathrm{ml}$ isopropyl alcohol, the sample was mixed, incubated at $-20^{\circ} \mathrm{C}$ for at least $3 \mathrm{~h}$ and centrifuged at $15,000 \mathrm{x} \mathrm{g}, 4^{\circ} \mathrm{C}$ for $30 \mathrm{~min}$. The obtained pellet was washed with $1 \mathrm{ml}$ ethanol in order to get rid of salts, dried and dissolved in 20-40 $\mu \mathrm{l}$ of autoclaved bidistilled water containing $2.5 \%$ of $80 \mathrm{mM}$ DTT (Applichem) solution and $2.5 \%$ of RNase Block (Stratagene). The sample was shock frozen in liquid nitrogen and stored at $-80^{\circ} \mathrm{C}$.

\subsection{RNA isolation from rat organs}

Isolated rat organs were cut into pieces with scissors and frozen in liquid nitrogen. Organ parts were crushed into fine powder in a pre-chilled mortar plate under constant freezing with liquid nitrogen. One fine spoon (micro spoon: 7 x $5 \mathrm{~mm}$, Ochs $\mathrm{GmbH}$, BovendenLenglern) of the powder was mixed with $3 \mathrm{ml}$ GTC solution in a sterile polypropylene centrifuge tube. The received homogeneous suspension was subjected to the following RNA extraction steps as described in chapter 2.2.2.4.1.1.

\subsection{Total RNA isolation using TRIzol ${ }^{\mathrm{TM}}$ reagent}

The TRIzol reagent is a ready-to-use reagent for the isolation of total RNA from cells and tissues. The reagent, a mono-phasic solution of phenol and guanidine isothiocyanate, is an improvement to the RNA isolation method developed by Chomczynski and Sacchi, 1987. One $\mathrm{ml}$ of TRIzol reagent was used to lyse $5 \times 10^{6}$ cells by pipetting up and down. The 
sample was incubated at room temperature (RT) to permit the complete dissociation of nucleoprotein complexes. Following addition of $0.2 \mathrm{ml}$ of chloroform (per $1 \mathrm{ml}$ of TRIzol reagent), the tube was capped securely and shaken vigorously by hand for 15 seconds. The sample was incubated for 2-3 min at RT and then centrifuged at 12,000 x g for $15 \mathrm{~min}$ at $4^{\circ} \mathrm{C}$. The upper aqueous phase containing the RNA was transferred into a fresh tube and mixed with $0.5 \mathrm{ml}$ of isopropyl alcohol per $1 \mathrm{ml}$ of TRIzol reagent used for the initial homogenization. The sample was incubated for $10 \mathrm{~min}$ at RT and centrifuged at $12,000 \mathrm{xg}$ for $10 \mathrm{~min}$ at $4^{\circ} \mathrm{C}$. The obtained RNA pellet was washed by vortexing with $1 \mathrm{ml} 70 \%$ ethanol (per $1 \mathrm{ml}$ of TRIzol) and centrifuged at $7,500 \mathrm{x} \mathrm{g}$ for $5 \mathrm{~min}$ at $4^{\circ} \mathrm{C}$. The pellet was air-dried for 5 - 10 min (retaining residual moisture), dissolved in $20-40 \mu \mathrm{l}$ of autoclaved bidistilled water by passing the solution a few times through a pipette tip, and incubated at $55^{\circ} \mathrm{C}$ for 10 $\min$.

\subsection{RNeasy Mini Kit}

RNA isolation using the RNeasy Mini Kit was performed according to the RNeasy Spin protocol with $4-5 \times 10^{6}$ cells (one $58 \mathrm{~cm}^{2}$ plate) per sample. All following steps were performed at room temperature $\left(20^{\circ} \mathrm{C}\right.$ between $\left.25^{\circ} \mathrm{C}\right)$ including centrifugation steps. The medium was completely aspirated and the cells washed with PBS. Six hundred $\mu$ l of lysis buffer were added to the cells and the cell lysate was collected with a rubber policeman. The lysate was pipetted into a $1.5 \mathrm{ml}$ Eppendorf tube and vortexed. One volume of $70 \%$ ethanol was added to the lysate and mixed well by pipetting. The lysate was applied to the RNeasy mini column placed in a $2 \mathrm{ml}$ collection tube in $700 \mu \mathrm{l}$ portions and centrifuged at $8,000 \mathrm{x} \mathrm{g}$ for $15 \mathrm{~min}$. The flow-through was discharged. The column was washed once with $700 \mu 1$ RW1 buffer and then twice with $500 \mu$ of RPE buffer. Every wash was followed by 15 seconds centrifugation at $8000 \mathrm{x} \mathrm{g}$ and the flow-through was discharged. The RNA was eluted in $30-50 \mu \mathrm{l}$ of RNase-free water through centrifugation for $1 \mathrm{~min}$ at 8,000 x $\mathrm{g}$ and stored at $-80^{\circ} \mathrm{C}$.

Extracted RNA samples were diluted 1:1000 for the measurement of RNA concentrations. 


\subsubsection{Determination of nucleic acid concentrations}

The photometric concentration measurement of both DNA and RNA was performed using the BioPhotometer (Eppendorf). The UV light absorbance was measured at $230 \mathrm{~nm}, 260 \mathrm{~nm}$ and $280 \mathrm{~nm}$ of nucleic acid samples and the ratios $A_{260} / A_{280}$ and $A_{260} / A_{230}$ were calculated. The factor for the conversion of UV absorbance into nucleic acid concentration in $\mu \mathrm{g} / \mathrm{ml}$ is 50.0 for DNA and 40.0 for RNA, meaning that if the light absorbance at $260 \mathrm{~nm}$ equals 1.0 , then there are $50 \mu \mathrm{g} / \mathrm{ml}$ of dsDNA or $40 \mu \mathrm{g} / \mathrm{ml}$ of ssRNA in the measured sample. On the basis of this definition the UV light absorption of nucleic acid samples was measured and the received OD (optical density) calculated into $\mu \mathrm{g} / \mathrm{ml}$. The ratios $\mathrm{A}_{260} / \mathrm{A}_{280}$ and $\mathrm{A}_{260} / \mathrm{A}_{230}$ indicate the contamination degree of sample measured with proteins and salts, respectively. The light absorbance at $230 \mathrm{~nm}$ of high purity samples should be approximately zero and the $\mathrm{A}_{260} / \mathrm{A}_{280}$ should be above 1.7, whereas the ratio $\mathrm{A}_{260} / \mathrm{A}_{230}$ should be beneath 2.0.

\subsubsection{Enzymatic modifications of nucleic acids}

\subsubsection{Cleavage of plasmid DNA with restriction enzymes}

The plasmid DNA was digested using restriction endonucleases (RE) purchased from different suppliers. Two types of restriction reactions were performed: a digestion reaction to prepare a vector and an insert DNA for sticky-end ligation and a general restriction reaction to analyze the obtained construct DNA. The general restriction reaction mixture of total volume was $10 \mu \mathrm{l}$ and contained:

$1 \mu$ plasmid DNA, obtained via mini-preparation (chapter 2.2.2.1).

$1 \mu 110 \times$ buffer

$0.5 \mu$ enzyme $(10 \mathrm{U} / \mu \mathrm{l})$

$7.5 \mu \mathrm{H} \mathrm{H}_{2} \mathrm{O}$ 
In the preparation of the recipient vector and insert DNA, vector and the insert were digested separately. The mixture for recipient vector digestion contained:

\author{
$0.5 \mu \mathrm{g}$ vector DNA \\ $1 \mu l$ enzyme $(10 \mathrm{U} / \mu \mathrm{l})$ \\ $5 \mu 110 \times$ buffer \\ water to $50 \mu \mathrm{l}$ of total reaction volume
}

Prior to ligation reaction, the vector DNA was dephosphorylated (chapter 2.2.3.2). The insert DNA was obtained via PCR (chapter 2.2.7.1) or was a part of another construct, for example, rAbcb7 in the TOPO-XL vector. The mixture for digestion of the insert DNA contained:

\author{
$4 \mu \mathrm{g}$ insert DNA \\ $5 \mu$ enzyme $(10 \mathrm{U} / \mu \mathrm{l})$ \\ $5 \mu 110 \times$ buffer \\ water to $50 \mu \mathrm{l}$ of total reaction volume
}

Double digestions with two enzymes were performed as follows: DNA was first digested with the enzyme that required $1 \mathrm{x}$ concentrated buffer and then the second, $2 \mathrm{x}$ concentrated buffer requiring enzyme with the proper amount of buffer, was added. All restriction reactions were carried out at $37^{\circ} \mathrm{C}$ within 1 to $3 \mathrm{~h}$. Finally, the enzymes were inactivated by heating the sample to $80^{\circ} \mathrm{C}$ for $20 \mathrm{~min}$ or the reaction mixture was loaded into agarose gel slots for DNA electrophoresis (chapter 2.2.10.1).

\title{
2.2.3.2 Dephosphorylation of vector DNA
}

The calf intestinal alkaline phosphatase (CIAP) catalyses the hydrolysis of the 5'-end phosphoric acid ester from DNA, RNA, ribo- and desoxiribonucleoside triphosphates, assuring that vector did not religate. The dephosphorylation of vector DNA was carried out after the restriction reaction by adding $1 \mathrm{U}$ CIAP/ $\mu \mathrm{g}$ vector DNA and incubating for 1 to $3 \mathrm{~h}$ at $37^{\circ} \mathrm{C}$. The dephosphorylation reaction was followed by DNA gel electrophoresis (chapter 2.2.10.1) and DNA purification from the gel using the QIAquick Gel Extraction Kit (Qiagen) 
or DNA extraction from low melting agarose (chapter 2.2.4.2).

\subsubsection{Isolation of DNA fragments from agarose gels}

DNA fragments were observed as bands after DNA gel electrophoresis. The bands were cut out of the gel under UV light on a transilluminator table. Depending on the type of agarose the gel was made of, two methods of DNA extraction from agarose gel slices were used. The QIAquick Gel extraction kit (Qiagen) was implemented for DNA isolation out of standard agarose gel slices. Alternatively, DNA was isolated from low melting agarose gel slices by agarose digestion with agarase.

\subsubsection{QIAquick Gel Extraction Kit}

QIAquick gel extraction kit contains a silica membrane assembly for binding of DNA in high-salt buffer and elution with low-salt buffer or water. A high molarity chaotropic sodium perchlorate salt $\left(\mathrm{NaClO}_{4}\right)$ solution $(\mathrm{pH} \leq 7.5)$ was added to the DNA embedded in $100 \mathrm{mg}$ of agarose slices and incubated at $50^{\circ} \mathrm{C}$ for $10 \mathrm{~min}$, resulting in irreversibly dissolved agarose. The homogeneous solution was subjected to filtration through the silica membrane of the QIAquick spin column. The DNA precipitate was washed and eluted with low-salt buffer ( $\mathrm{pH}$ 8.5). The volumes of buffers were used as recommended in the protocol of the kit.

\subsubsection{Agarase digestion method}

Low melting (LM) agarose is derived by organic synthesis, which generates methoxylate groups from the basic agarose structure. The main properties of LM-agarose are the low melting $\left(\leq 65^{\circ} \mathrm{C}\right)$ and gelling $\left(\leq 28^{\circ} \mathrm{C}\right)$ temperatures when compared with standard agarose. DNA containing LM-agarose was melted at $65^{\circ} \mathrm{C}$ for $5-10$ min and chilled to $42^{\circ} \mathrm{C}$. The addition of $1 \mathrm{U}$ of $\beta$-agarase (valid for $1 \%$ LM-agarose gels) was followed by incubation at $42^{\circ} \mathrm{C}$ for $1 \mathrm{~h}$, assuring the irreversible digestion of agarose. DNA was precipitated as described in chapter 2.2.5. 


\subsubsection{DNA precipitation}

To precipitate DNA from $20 \mu \mathrm{l}$ of solution, the following volume of solutions were added:

$1 \mu$ glycogen solution $(20 \mathrm{mg} / \mathrm{ml})$

$2 \mu 13 \mathrm{M}$ sodium acetate solution ( $\mathrm{pH} 4.6)$

$40 \mu$ isopropanol

The reaction mixture was mixed and centrifuged at $21,910 \mathrm{x} \mathrm{g}$, at $4{ }^{\circ} \mathrm{C}$ for $20 \mathrm{~min}$. The obtained DNA pellet was washed with $80 \%$ ethanol, centrifuged at $21,910 \times \mathrm{g}$, at $4{ }^{\circ} \mathrm{C}$ for 5 min, air-dried and dissolved in $10-20 \mu l$ of autoclaved bidistilled water.

\subsubsection{Cloning of DNA fragments}

\subsubsection{Topoisomerase-mediated DNA ligation}

This method (patented by Invitrogen) allows direct ligation of a PCR product into different cloning and expression vectors (pCR-XL-TOPO, pcDNA3.1/V5-His), resulting in a higher ligation efficiency than the classic ligation method using T4-ligase. TOPO vector solutions contain linearized vectors, which exhibit $\mathrm{T}$ nucleotide overhangs at the 3 '-ends that complement to the terminal A attached by Taq polymerase to the 3'-ends of PCR products. The ligation reaction is catalyzed by topoisomerase, an enzyme that is associated with the TOPO vector. According to the Invitrogen protocol, freshly synthesized PCR product was mixed with the selected vector, within a total volume of $6 \mu \mathrm{l}$ and incubated at RT for $5 \mathrm{~min}$. The addition of $1 \mu$ of concentrated salt solution $\left(0.3 \mathrm{M} \mathrm{NaCl}, 0.06 \mathrm{M} \mathrm{MgCl}_{2}\right)$ terminated the ligation reaction. The product of ligation reaction was either directly electroporated into electro-competent E. coli (chapter 2.2.6.4) or first precipitated (chapter 2.2.5) to reduce the salt concentration in the ligation reaction mixture to avoid a short circuit during the pulse. 


\subsubsection{Ligation with T4-DNA ligase}

DNA fragments, digested and purified, were ligated into vector molecules digested with the same restriction enzymes via the complementation of the "sticky ends". The enzyme T4 DNA ligase catalyzed the ligation reaction. A vector: insert ratio of 1:2 yielded the best results. The total ligation reaction volume of $20 \mu \mathrm{l}$ contained $2 \mu \mathrm{l}$ of ligation buffer $(10 \mathrm{x}), 1$ $\mu 1$ T4 DNA ligase and autoclaved bidistilled water. The ingredients were mixed and incubated at RT over night. The ligation reaction was followed by DNA precipitation (chapter 2.2.5). The obtained DNA pellet was dissolved in $5-10 \mu \mathrm{l}$ of autoclaved water.

\subsubsection{Production of electro-competent $E$. coli cells}

Twenty $\mu 1$ of electro-competent E. coli stock (purchased from Invitrogen) were transferred into $6 \mathrm{ml}$ of antibiotic-free LB medium to produce a preparatory culture by shaking at $37^{\circ} \mathrm{C}$ over night. The preparatory culture was equally distributed into 3 x $200 \mathrm{ml}$ of LB medium and cultured by shaking at $37^{\circ} \mathrm{C}$ until the OD600 had reached $0.65-0.8$. The bacteria suspension was chilled on ice and aliquoted into twelve $50 \mathrm{ml}$ tubes (Sarstedt). All further steps were performed on ice or at $4^{\circ} \mathrm{C}$ (centrifugation). Tubes were centrifuged at $3220 \mathrm{x} \mathrm{g}$ at $4^{\circ} \mathrm{C}$ for $10 \mathrm{~min}$. The 12 pellets were resuspended in $1 \mathrm{ml} /$ pellet of ice-cold $10 \%$ glycerol (in autoclaved bidistilled water) and the tubes were filled up to $30 \mathrm{ml}$ with $10 \%$ glycerol. Tubes were centrifuged at $3220 \mathrm{x} \mathrm{g}$, at $4^{\circ} \mathrm{C}$ for $10 \mathrm{~min}$ and the pellets were resuspended in 1 $\mathrm{ml} /$ pellet of ice-cold $10 \%$ glycerol. Two pellets were unified, resulting in 6 tubes that were filled up to $30 \mathrm{ml}$ of ice-cold $10 \%$ glycerol solution and centrifuged again at $3220 \mathrm{xg}$, at $4^{\circ} \mathrm{C}$ for $10 \mathrm{~min}$. The 6 pellets were resuspended in $1 \mathrm{ml} /$ pellet of ice-cold $10 \%$ glycerol solution. Two pellets were pooled together, resulting in 3 tubes that were filled up to $30 \mathrm{ml}$ with icecold $10 \%$ glycerol solution and centrifuged again at $3220 \mathrm{x} \mathrm{g}$, at $4^{\circ} \mathrm{C}$ for $10 \mathrm{~min}$. The 3 pellets were carefully resuspended in $400 \mu \mathrm{l} /$ pellet of $10 \%$ glycerol, aliquoted at $60 \mu \mathrm{l} /$ prechilled cup, shock frozen in liquid nitrogen and stored at $-80^{\circ} \mathrm{C}$. 


\subsubsection{Transformation via electroporation}

An aliquot of electro-competent $E$. coli stock was used for the transformation of one ligation reaction result. The electro-competent $E$. coli stock was thawed on ice for $20 \mathrm{~min}$, mixed gently with DNA by circling inside the cup with a sterile pipette tip and transferred into a pre-chilled cuvette that exhibited $2 \mathrm{~mm}$ distance between the electrodes. The electroporation conditions were $2500 \mathrm{~V}, 25 \mu \mathrm{F}, 200 \Omega$. Five hundred $\mu \mathrm{l}$ of pre-warmed SOC medium were added at once to the electroporated bacteria. The LB-bacteria mixture was transferred to a tube, shaken at $37^{\circ} \mathrm{C}$ for $1 \mathrm{~h}$ and distributed on the selective LB-agar plates containing a proper antibiotic. The plates were incubated at $37^{\circ} \mathrm{C}$ for $12-24 \mathrm{~h}$. Resulting E. coli colonies were analyzed via plasmid mini-preparation (chapter 2.2.2.1) followed by restriction analysis (chapter 2.2.3.1).

\subsubsection{PCR techniques}

The polymerase chain reaction (PCR) method allows to amplify a specific DNA template from a pool of available ones. DNA templates were heat denatured to enable a templatespecific pair of primers to anneal to the complementary template strands. The primers were extended by adding nucleotides in 5' to 3' direction by thermostable DNA polymerase. New dsDNA molecules were denaturated by heat and used in a new cycle as templates. The cycle, consisting of denaturation, primer annealing and primer extension steps was repeated $20-35$ times. The second cycle yielded DNA fragments equal in length to the distance between the used sense and anti-sense primers. With every PCR cycle the amount of amplified DNA sequence doubled and theoretically after $n$ cycles $2^{\mathrm{n}}$ DNA molecules of desired length and specificity were expected. The PCR products were analyzed via agarose gel electrophoresis (chapter 2.2.10.1) 


\subsubsection{PCR using plasmid DNA as a template}

A PCR method was used to add restriction enzyme sites to insert cDNA via cDNA amplification to facilitate the cloning reaction of the insert cDNA into the vector. A plasmid bearing the cDNA sequence was used as a template for the amplification reaction with primers containing restriction enzyme sites. The sites were afterwards activated by cleavage with the restriction enzymes (chapter 2.2.3.1) yielding sticky ends, enabling the ligation of the insert into a new plasmid (chapter 2.2.6). For the PCR reaction following reagents were mixed together on ice:

$1 \mu \mathrm{l}$ template DNA $(50 \mathrm{ng} / \mu \mathrm{l})$

$2 \mu \mathrm{l}$ restriction site containing sense primer $(10 \mu \mathrm{M})$, for instance, containing the NheI site for rAbcb6 amplification

$2 \mu \mathrm{l}$ restriction site containing anti-sense primer $(10 \mu \mathrm{M})$, for instance, containing the SalI site for rAbcb6 cDNA amplification

$2 \mu \mathrm{MgCl} \mathrm{Mg}_{2}(50 \mathrm{mM})$

$5 \mu \mathrm{dNTP}(2 \mathrm{mM})$

$1 \mu 1$ Taq polymerase

$5 \mu l$ buffer $(10 \mathrm{x})$

$32 \mu \mathrm{H}_{2} \mathrm{O}$

The Taq DNA polymerase, isolated from the thermophilic eubacterium Thermus aquaticus $B M$, was a highly processive 5' -3 'DNA polymerase that lacked 3 ' -5 ' exonuclease activity. Different plasmids were used as template DNAs, for example, a pCR-XL-TOPO vector bearing the rAbcb6 cDNA sequence. Sense and anti-sense primers depended on the sequence that was to be amplified (table 3, chapter 2.1.7.1). 
For the PCR reaction the following PCR protocol was used:

Pre-denaturation

25 cycles of:

Denaturation

Annealing

Extension $94^{\circ} \mathrm{C}$ for $2 \mathrm{~min}$

$94^{\circ} \mathrm{C}$ for $25 \mathrm{~s}$

$55^{\circ} \mathrm{C}$ for $30 \mathrm{~s}$, gradient $\pm 5^{\circ} \mathrm{C}$

$68^{\circ} \mathrm{C}$ for $3 \mathrm{~min}$

Final extension $\quad 72^{\circ} \mathrm{C}$ for $10 \mathrm{~min}$

A gradient in the primer annealing step allowed to optimize the annealing temperature for primers used. The number of PCR cycles was kept as low as possible to minimize the probability to detect false nucleotide incorporations into the insert sequence.

\subsubsection{Reverse transcription - PCR (RT-PCR)}

The mRNA was translated into copy or complementary DNA (cDNA) via the reverse transcription reaction and the obtained cDNA was then amplified via PCR. The two sequential enzyme reactions were performed with a mixture containing both enzymes (via the so-called "one-step" RT-PCR approach). For the performance of one-step RT-PCR, kits from Invitrogen and Roche were used. The following reaction mixture was prepared on ice:

$1 \mu \mathrm{l}$ total rat RNA $(1 \mu \mathrm{g} / \mu \mathrm{l})$

$2.5 \mu \mathrm{l}$ sense primer $(10 \mu \mathrm{M})$

$2.5 \mu \mathrm{l}$ anti-sense primer $(10 \mu \mathrm{M})$

$2.5 \mu$ DTT solution

$1 \mu \mathrm{l}$ Rase inhibitor

$4 \mu \mathrm{dNTP}(2 \mathrm{mM})$

$1 \mu$ enzyme mixture

$10 \mu \mathrm{l}$ buffer $(5 \mathrm{x})$

$25.5 \mu 1 \mathrm{H}_{2} \mathrm{O}$ 
The enzyme mixture of the Invitrogen kit contained the SuperScript ${ }^{\circledR}$ III reverse transcriptase and Platinum ${ }^{\circledR}$ Taq polymerase. The SuperScript ${ }^{\circledR}$ III reverse transcriptase was a modification of M-MLV reverse transcriptase (isolated from moloney murine leukemia virus) that was engineered to allow the cDNA synthesis at $45-60^{\circ} \mathrm{C}$ instead of the usual 37 $42^{\circ} \mathrm{C}$ cDNA synthesis temperature of the reduced RNase $\mathrm{H}$ activity containing original MMLV reverse transcriptase. The Platinum ${ }^{\circledR}$ Taq polymerase was a recombinant Taq DNA polymerase complexed with a proprietary antibody that blocked polymerase activity at ambient temperatures. Activity was restored after the denaturation step, performed at $94^{\circ} \mathrm{C}$. The "Titan One Tube RT-PCR" kit from Roche contained so-called "Titan enzyme mix". The mix included the AMV reverse transcriptase (isolated from avian myeloblastosis virus) and the Expand high fidelity enzyme blend that contained a proofreading polymerase and Taq polymerase. The following temperature protocol was used:

cDNA synthesis:

$45^{\circ} \mathrm{C}$ for $30 \mathrm{~min}$

Pre-denaturation:

$94^{\circ} \mathrm{C}$ for $2 \mathrm{~min}$

Reverse transcriptase was denatured after initial cDNA synthesis by the high temperature.

10 cycles of:

$$
\begin{array}{ll}
\text { Denaturation: } & 94^{\circ} \mathrm{C} \text { for } 15 \mathrm{~s} \\
\text { Primer annealing: } & 60^{\circ} \mathrm{C} \text { for } 30 \mathrm{~s} \\
\text { Extension: } & 68^{\circ} \mathrm{C} \text { for } 3 \mathrm{~min}
\end{array}
$$

15 cycles of: $\quad$ Denaturation: $\quad 94^{\circ} \mathrm{C}$ for $15 \mathrm{~s}$

Primer annealing: $\quad 60^{\circ} \mathrm{C}$ for $30 \mathrm{~s}$

Extension: $\quad 68^{\circ} \mathrm{C}$ for $3 \mathrm{~min}+5 \mathrm{~s} /$ cycle

Final extension: $\quad 72^{\circ} \mathrm{C}$ for 6 min 


\subsubsection{3 5'-RACE-PCR}

Verification of the rat Abcb7 5' coding sequence was performed by applying a "rapid amplification of cDNA ends" (RACE) method according to Frohmann et al. (1994). The cDNA was synthesized from the total rat hepatocyte RNA pool using the rAbcb7 sequencespecific reverse primer B7R4. Reagents were mixed as follows:

$3 \mu \mathrm{l}$ total rat RNA $(1 \mu \mathrm{g} / \mu \mathrm{l})$

$1 \mu \mathrm{l}$ anti-sense primer B7R4 $(10 \mu \mathrm{M})$

$1 \mu \mathrm{DTT}$ solution

$1 \mu 1$ RNase inhibitor

$8 \mu \mathrm{dNTP}(2 \mathrm{mM})$

$1 \mu \mathrm{l}$ Thermoscript reverse transcriptase ( $15 \mathrm{U} / \mu 1$, Roche)

$4 \mu \mathrm{l}$ buffer $(5 \mathrm{x})$

$32 \mu \mathrm{H}_{2} \mathrm{O}$

The incubation of reaction mixture at $60^{\circ} \mathrm{C}$ for $60 \mathrm{~min}$ was followed by enzyme inactivation at $85^{\circ} \mathrm{C}$ for $5 \mathrm{~min}$. The received cDNA was purified according to the protocol supplied with the High Pure PCR Purification kit (Roche) and tailed with dATP at its 3'-end by mixing together:

$19 \mu \mathrm{l}$ cDNA sample

$2.5 \mu \mathrm{l}$ reaction buffer ( $10 \times$ concentrated; vial 5)

$2.5 \mu \mathrm{l} 2 \mathrm{mM}$ dATP (vial 4)

The cDNA was denatured at $94^{\circ} \mathrm{C}$ for 3 min. The tube was chilled on ice and briefly spun down. $1 \mu \mathrm{l}$ of terminal transferase was added to the reaction mixture. The mixture was mixed, incubated at $37^{\circ} \mathrm{C}$ for $20 \mathrm{~min}$ and the enzyme was inactivated by incubating the mixture at $70^{\circ} \mathrm{C}$ for $10 \mathrm{~min}$. Tailed cDNA was amplified via PCR using the oligo dT-anchor primer and a nested B7R3 primer. Following reagent volumes were mixed: 
$5 \mu l$ tailed cDNA

$1.5 \mu$ l oligo dT-anchor primer $(10 \mu \mathrm{M})$

$1.5 \mu \mathrm{l}$ cDNA-specific anti-sense primer B7R2 $(10 \mu \mathrm{M})$

$5 \mu \mathrm{dNTP}(2 \mathrm{mM})$

$1 \mu 1$ Long Expand enzyme mix

$5 \mu \mathrm{l}$ buffer $(10 \mathrm{x})$

$31 \mu 1 \mathrm{H}_{2} \mathrm{O}$

The Long Expand enzyme mix was a blend of thermostable Taq and Tgo DNA polymerases. The Tgo DNA polymerase, isolated from the thermophilic archaebacterium Thermococcus gorgonarius, was a highly processive $5^{\prime} \rightarrow 3^{\prime}$ DNA polymerase with an above average $3^{\prime} \rightarrow 5^{\prime}$ exonuclease activity. The PCR was performed according to the following temperature protocol:

Pre-denaturation:

$94^{\circ} \mathrm{C}$ for $2 \mathrm{~min}$

10 cycles of:

Denaturation:

$94^{\circ} \mathrm{C}$ for $15 \mathrm{~s}$

Primer annealing: $\quad 60^{\circ} \mathrm{C}$ for $30 \mathrm{~s}$

Extension:

$68^{\circ} \mathrm{C}$ for $3 \mathrm{~min}$

20 cycles of:

Denaturation: $\quad 94^{\circ} \mathrm{C}$ for $15 \mathrm{~s}$

Primer annealing: $\quad 60^{\circ} \mathrm{C}$ for $30 \mathrm{~s}$

Extension:

$68^{\circ} \mathrm{C}$ for $3 \mathrm{~min}+20 \mathrm{~s} /$ cycle

Final extension: $\quad 68^{\circ} \mathrm{C}$ for $6 \mathrm{~min}$

The RACE-PCR product was cloned into the TOPO XL vector (chapter 2.2.6.1) and sequenced (chapter 2.2.9). The full coding $\mathrm{rAbcb} 7 \mathrm{cDNA}$ sequence was received via the onestep RT-PCR using mRNA extracted from primary rat hepatocytes and B7R6, B7F6 primers. 


\subsubsection{Construction of expression vectors bearing rAbcb6 and $\mathrm{rAbcb} 7 \mathrm{cDNA}$}

The rAbcb7 and rAbcb6 cDNA sequences were obtained applying RT-PCR as described in chapter 2.2.7.2. Total RNA extracted from rat hepatocytes (chapter 2.2.2.4) was used as a template for the RT-PCR. Primers B7F6 and B7R6 (chapter 2.1.7.3) used to synthesize rAbcb7 cDNA were expected to yield the $2.264 \mathrm{~kb}$ cDNA fragment. The $2.541 \mathrm{~kb}$ long rAbcb6 cDNA was expected to result from B6F1 and B6R1 primers (chapter 2.1.7.3). The obtained RT-PCR products were subjected to DNA gel electrophoresis (chapter 2.2.10.1). The approximately $2.3 \mathrm{~kb}$ long rAbcb7 and $2.5 \mathrm{~kb}$ long rAbcb6 bands were purified from the gel (chapter 2.2.4). The cDNA sequences were cloned via TOPO TA ligation (chapter 2.2.6.1) into the pCR-XL-TOPO vector to permit the elucidation of separate cDNA molecules. Electro-competent bacteria were transformed with the obtained constructs by electroporation (chapter 2.2.6.4), amplified and purified (chapter 2.2.2.3). The inserts were sequenced (chapter 2.2.9) via primer walking with primers displayed in tables 1 and 2 , chapter 2.1.7.3. Starting sequencing reactions were performed with commercially available primers M13 forward (5'-GTAAAACGACGGCCAG-3') and M13 reverse (5'CAGGAAACAGCTATGAC-3') positioned on the vector sequence flanking the TA-cloning site. The rAbcb6 and rAbcb7 sequences that were found to be in accordance with the reference sequences were used for further subcloning into mammalian expression vectors listed in table 7.

For subcloning of the rAbcb7-DsRed2 construct, the rAbcb7-Topo-XL and the pDsRed2-N1 vector (BD Biosciences) were digested with Eco RI (chapter 2.2.3.1). The digested pDsRed2-N1 and rAbcb7 insert were subjected to DNA gel electrophoresis (chapter 2.2.10.1), purified (chapter 2.2.4) and religated (chapter 2.2.6.2). The obtained construct was analyzed via general restriction reaction (chapter 2.2.3.1) and the positive clones were sequenced (chapter 2.2.9) to make sure that the rAbcb7 was in-frame with the DsRed2 coding sequence. 


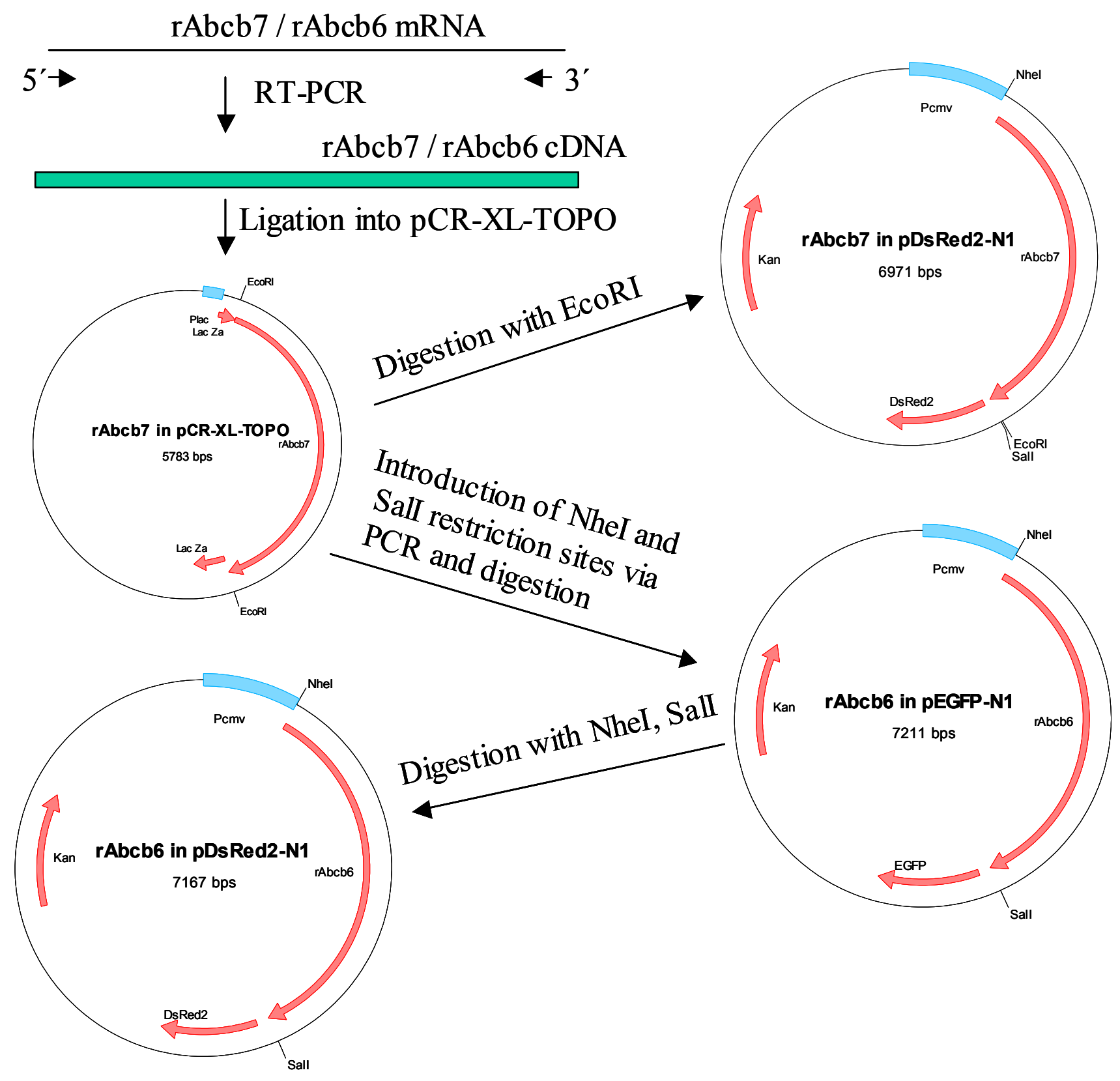

Figure 2. The strategy of expression vector construction. rAbcb6 and rAbcb7 cDNA were obtained via RT-PCR from rat hepatocyte RNA, ligated into the pCR-XL-TOPO vector and sequenced. The rAbcb6/rAbcb7 sequences that corresponded to the reference sequences were used for subcloning into expression vectors pDsRed2-N1 and pEGFP-N1. To obtain the rAbcb7-DsRed2 construct, the rAbcb7-Topo-XL plasmid and the pDsRed2-N1 vector were digested with Eco RI and the rAbcb7 sequence was ligated into pDsRed2-N1 vector. For subcloning of rAbcb6-EGFP, the pEGFP-N1 vector and the rAbcb6 sequence, obtained from rAbcb6-XL plasmid via PCR with primers containing NheI and Sall restriction sites, were digested with NheI and SalI enzymes and religated. The rAbcb6-DsRed2 construct was obtained via double digestion of the rAbcb6-EGFP plasmid and the pDsRed2-N1 vector with NheI and SalI enzymes followed by rAbcb6 and pDsRed2-N1 religation. 
The rAbcb7-DsRed2 construct was used for subcloning of rAbcb7-EGFP and rAbcb7-V5His via restriction site-specific ligation with T4 DNA ligase (chapter 2.2.6.2). The rAbcb7DsRed2 construct and pEGFP-N1 vector (BD Biosciences) were digested with NheI and AgeI enzymes (chapter 2.2.3.1) and subjected to DNA gel electrophoresis (chapter 2.2.10.1). The digested rAbcb7 insert and the pEGFP-N1 vector were purified from the gel (chapter 2.2.4) and religated (chapter 2.2.6.2). The obtained construct was analyzed via general restriction reaction (chapter 2.2.3.1) and the positive clones were sequenced (chapter 2.2.9) to make sure that the $\mathrm{rAbcb} 7$ sequence was in-frame with the EGFP coding sequence.

For subcloning of rAbcb7 into the pcDNA3.1/V5-His TOPO vector (Invitrogen), a PCR (chapter 2.2.7.1) was performed for introduction of XhoI and HindIII restriction sites. The XhoI and HindIII restriction sites containing primers (chapter 2.1.7.3, table 3) were used for rAbcb7 cDNA amplification from the rAbcb7-DsRed2 construct. The PCR product and the pcDNA3.1/V5-His TOPO vector were digested with XhoI and HindIII enzymes (chapter 2.2.3.1), subjected to DNA gel electrophoresis (chapter 2.2.10.1), purified (chapter 2.2.4) and religated (chapter 2.2.6.2). The obtained construct was analyzed via general restriction reaction (chapter 2.2.3.1) and the positive clones were sequenced (chapter 2.2.9) to make sure that the $\mathrm{rAbcb} 7 \mathrm{cDNA}$ sequence was identical to the sequence deposited in the EMBL database and in-frame with the tag protein, V5-His.

Table 7. Basic information about expression vectors used.

\begin{tabular}{lll}
\hline Vector & Promotor & Tag size \\
\hline & & \\
pEGFP-N1 & $\mathrm{P}_{\mathrm{CMV} \text { IE }}$ & $717 \mathrm{bp}, 239 \mathrm{aa}, 26.29 \mathrm{kDa}$ \\
pDsRed2-N1 & $\mathrm{P}_{\mathrm{CMV} \text { IE }}$ & $675 \mathrm{bp}, 225 \mathrm{aa}, 24.75 \mathrm{kDa}$ \\
pcDNA3.1/V5-His TOPO & $\mathrm{P}_{\mathrm{CMV}}$ & $135 \mathrm{bp}, 45 \mathrm{aa}, 4.95 \mathrm{kDa}$ \\
\hline
\end{tabular}

The rAbcb6-EGFP construct was obtained via religation of the rAbcb6 sequence and the pEGFP-N1 vector, following digestion with NheI and SalI (chapter 2.2.3.1), as it is schematically shown in figure 2. The rAbcb6 cDNA was obtained via PCR with primers containing NheI and SalI restriction sites from rAbcb6-TOPO-XL construct DNA (chapter 2.2.7.1). 
For subcloning of the rAbcb6-DsRed2 construct, the rAbcb6-EGFP and the pDsRed2-N1 vector were digested with NheI and SalI (chapter 2.2.3.1) and subjected to DNA gel electrophoresis (chapter 2.2.10.1). The digested rAbcb6 and pDsRed2-N1 vector were purified from the gel (chapter 2.2.4) and religated (chapter 2.2.6.2). The obtained construct was analyzed via general restriction reaction (chapter 2.2.3.1) and the positive clones were sequenced (chapter 2.2.9) to make sure that the rAbcb6 was in-frame with the sequence of DsRed2.

The rAbcb6-V5 bearing vector was constructed via topoisomerase-mediated DNA ligation (chapter 2.2.6.1) of rAbcb6 cDNA sequence amplified via RT-PCR (chapter 2.2.7.2) from primers B6R3 and B6F6 (chapter 2.1.7.3, table 1).

Table 8. The size of received constructs and deduced fusion protein characteristics: length in amino acids (aa) and mass in kilo Daltons (kDa).

\begin{tabular}{lll}
\hline Expressed fusion protein & Construct size & Calculated fusion protein size \\
\hline rAbcb6-EGFP & $7211 \mathrm{bp}$ & $1069 \mathrm{aa}, 118.5 \mathrm{kDa}$ \\
rAbcb7-EGFP & $6971 \mathrm{bp}$ & $1010 \mathrm{aa}, 111.2 \mathrm{kDa}$ \\
rAbcb6-DsRed2 & $7167 \mathrm{bp}$ & $1080 \mathrm{aa}, 118.8 \mathrm{kDa}$ \\
rAbcb7-DsRed2 & $6971 \mathrm{bp}$ & $1010 \mathrm{aa}, 111.2 \mathrm{kDa}$ \\
rAbcb6-V5 & $8031 \mathrm{bp}$ & $895 \mathrm{aa}, 98.4 \mathrm{kDa}$ \\
rAbcb7-V5 & $7836 \mathrm{bp}$ & $797 \mathrm{aa}, 87.7 \mathrm{kDa}$ \\
\hline
\end{tabular}

\subsubsection{Sequencing analysis}

The fluorescence-based cycle sequencing reactions were performed with the Big Dye Terminator v1.1 cycle sequencing kit (Applied Biosystems) in the department of Clinical Pharmacology according to modification of the method of Sanger et al. (1977). A forward or a reverse primer was used for DNA synthesis along the template DNA to be sequenced. Due to DNA polymerase activity desoxynucleotides were incorporated into newly synthesized DNA. Incorporation of fluorescence-labelled didesoxynucleotide led to DNA termination. 
The products of DNA synthesis represented a statistical mixture of DNA fragments of different length that ended with a fluorescent didesoxynucleotide. The sequencing mixture contained $1 \mu \mathrm{l}$ of sequencing primer $(10 \mu \mathrm{M}), 1.6 \mu \mathrm{l}$ of Big Dye solution that included fluorescence-labeled ddNTPs, dNTPs, buffer and DNA polymerase, $0.5 \mu$ DMSO, $1 \mu \mathrm{l}$ of plasmid DNA purified via mini-preparation (chapter 2.2.2.1) and autoclaved bidistilled water up to a total of $10 \mu \mathrm{l}$ of the reaction mixture volume. The following temperature protocol was used:

Initial denaturation:

$94^{\circ} \mathrm{C}$ for $2 \mathrm{~min}$

24 cycles of:
Denaturation:
$96^{\circ} \mathrm{C}$ for $15 \mathrm{~s}$
Primer annealing:
$56.5^{\circ} \mathrm{C}$ for $15 \mathrm{~s}$
Extension:
$60^{\circ} \mathrm{C}$ for $4 \mathrm{~min}$

Final extension: $\quad 60^{\circ} \mathrm{C}$ for $4 \mathrm{~min}$

After completion of the reaction cycles, $30 \mu \mathrm{l}$ of bidistilled water were added to the mixture. The mixture was subjected to filtration through sephadex (Sephadex G-50 superfine, Amersham) via centrifugation at $652 \mathrm{x}$ g for $5 \mathrm{~min}$ and loaded into the capillary sequencer 3100 Genetic Analyser (ABI). The sephadex was positioned in the wells of the 96 well plate MAHV N45 (Millipore) and prepared as follows. The sephadex was left to swell in $300 \mu$ of autoclaved bidistilled water per well for at least $3 \mathrm{~h}$ at room temperature, centrifuged at 652 $\mathrm{x} g$ for $5 \mathrm{~min}$, repeatedly left to swell in $150 \mu \mathrm{l}$ of water per well for $15 \mathrm{~min}$ and centrifuged at $652 \mathrm{x} \mathrm{g}$ for $5 \mathrm{~min}$. The raw data analysis was made by the standard programme of 3100 $\mathrm{ABI}$ and evaluated with following PC software:

Sequencing Analysis (Perkin Elmer)

Chromas (Technelysium)

The Clustal W (EBI) programme was used to compare sequenced nucleotide sequences to specific sequences extracted from EMBL and Genbank databases. 


\subsubsection{DNA gel electrophoresis}

The following buffers were required for DNA gel electrophoresis:

TBE buffer $10 \times(\mathrm{pH} \mathrm{8.3)}$

$\begin{array}{ll}1 \mathrm{M} & \text { boric acid } \\ 1 \mathrm{M} & \text { Tris }\end{array}$

$20 \mathrm{mM}$

EDTA

The $\mathrm{pH}$ was adjusted with $32 \% \mathrm{HCl}$ to 8.3 .

DNA sample buffer $6 \mathrm{x}$ :

$$
\begin{array}{ll}
60 \%(\mathrm{v} / \mathrm{v}) & 10 \mathrm{x} \text { tris-acetate buffer }(\mathrm{pH} 7.2) \\
30 \%(\mathrm{v} / \mathrm{v}) & \text { glycerol } \\
0.15 \%(\mathrm{w} / \mathrm{v}) & \text { bromphenol blue } \\
0.15 \%(\mathrm{w} / \mathrm{v}) & \text { xylene cyanol } \\
10 \%(\mathrm{v} / \mathrm{v}) & \text { bidistilled water }
\end{array}
$$

This method was used to analyze small amounts of DNA $(\leq 1 \mu \mathrm{g})$ after PCR, RT-PCR or restriction reaction, or to separate large amounts of DNA $(\leq 10 \mu \mathrm{g})$. Depending on the size of expected DNA fragments, the $0.6-1 \%$ agarose gels were prepared with $1 \times$ TBE buffer. The proper amount of agarose was dissolved in $1 / 2$ of the amount of TBE required, heated till boiling and then diluted to the required volume $(100 \mathrm{ml})$ with $1 \mathrm{x}$ TBE room temperature buffer. After addition of $5 \mu \mathrm{l}$ of ethidium bromide (stock solution $10 \mathrm{mg} / \mathrm{ml}$ ), the agarase mixture was poured into the prepared gel tray $(14 \times 11 \times 0.7 \mathrm{~cm})$. The gel solidified at RT within $30-60 \mathrm{~min}$ and was transferred into a horizontal electrophoresis chamber filled with $1 \mathrm{x}$ TBE buffer. DNA samples were mixed with $5 \mu \mathrm{l}$ of DNA loading buffer and loaded into gel slots. The gel was run at $45-110 \mathrm{~mA}$ for $2-4 \mathrm{~h}$. Due to the interaction of DNA with ethidium bromide, the separated DNA bands were visualized under UV light and documented by taking a photo of the gel. The bands of interest were cut out with a scalpel and purified (chapter 2.2.4). The size of DNA bands was determined via their comparison with the bands of a DNA standard ladder (chapter 2.1.8). 


\subsubsection{Denaturating RNA gel electrophoresis}

The following buffer stock solution was required for gel casting and RNA electrophoresis:

$\begin{array}{lll}\text { MOPS buffer (10 x, pH 7.4): } & 0.2 \mathrm{M} & \text { MOPS } \\ & 50 \mathrm{mM} & \text { sodium acetate } \\ & 10 \mathrm{mM} & \text { EDTA }\end{array}$

After the adjustment of $\mathrm{pH}$, the buffer was autoclaved. Dilution of $10 \times$ MOPS at a ratio of 1:10 with autoclaved bidistilled aqua resulted in the working solution.

One percent agarose gels were cast for RNA analysis. One g agarose was weighted into an autoclaved glass and dissolved in $90 \mathrm{ml}$ of 3-(N-morpholino)-propane sulfuric acid (MOPS) buffer by boiling. After the solution chilled down to $50^{\circ} \mathrm{C}, 10 \mathrm{ml}$ of $37 \%$ formaldehyde solution were added and the mixture was poured into the gel tray $(14 \times 11 \times 0.7 \mathrm{~cm})$. A comb was inserted to produce slots within the gel. Prior to pouring the gel, the gel tray and the comb were incubated for $30 \mathrm{~min}$ with $50 \mathrm{mM} \mathrm{NaOH}$ solution to inactivate RNases.

The following solutions were required for RNA sample preparation:

Blue buffer:

$\begin{array}{ll}5 \mathrm{mM} & \mathrm{Na}_{2} \mathrm{HPO}_{4} \\ 0.45 \% & \text { bromphenol blue (w/v) } \\ 13.7 \mathrm{mM} & \text { glycerol }\end{array}$

Formamide mix: $\quad 16.5 \mathrm{M} \quad$ formamide (deionized)

$13.2 \% \quad$ MOPS $(10 \mathrm{x}, \mathrm{v} / \mathrm{v})$

$2.7 \mathrm{M} \quad$ formaldehyde $(37 \%)$

Deionization of formamide was performed as follows: $50 \mathrm{ml}$ formamide were stirred for 30 min with $5 \mathrm{~g}$ Serdolit MB-1-ion exchanger, subjected to filtration, aliquoted and stored at $-20^{\circ} \mathrm{C}$. The sample buffer was prepared by mixing the blue buffer, formamide mix and the ethidium bromide solution $(10 \mathrm{mg} / \mathrm{ml})$ in the volume proportions $50+250+1$, respectively and stored at $4^{\circ} \mathrm{C}$. 
Total RNA samples were prepared for loading onto the gel by the following procedure: $5 \mu 1$ of sample buffer was added to the RNA solution containing $20-25 \mu \mathrm{g}$ RNA and diluted with autoclaved water to $30 \mu \mathrm{l}$. The samples were incubated at $65^{\circ} \mathrm{C}$ for $10 \mathrm{~min}$ for denaturation, chilled on ice, centrifuged briefly and loaded into the gel slots.

The solidified agarose was fixed to the gel tray, transferred into the electrophoresis chamber filled with $1 \mathrm{x}$ MOPS buffer and the slot comb was removed. Two $\mu$ l of sample buffer per slot were loaded to test the slot quality. The denatured RNA samples were subsequently loaded. Electrophoresis was performed at $10 \mathrm{~mA}$ for $30-60 \mathrm{~min}$ and then at $40-45 \mathrm{~mA}$ for another $3 \mathrm{~h}$ under recirculation of electrophoresis buffer. At the end, equal loading of gel lanes with RNA was tested under UV light and documented by means of Polaroid photography. RNA bands were visible due to RNA interaction with ethidium bromide. The $18 \mathrm{~S}$ and $28 \mathrm{~S}$ rRNA bands (1.9 kb and $4.8 \mathrm{~kb}$, respectively) were used as molecular weight markers.

\subsubsection{RNA transfer onto the nylon membrane (Northern blot)}

The following stock solution was required for RNA transfer onto the nylon membrane:

$\begin{array}{lll}\text { SSC (20 x, pH 7.0): } & 3 \mathrm{M} & \mathrm{NaCl} \\ & 0.3 \mathrm{M} & \text { tri-sodium citrate }\end{array}$

The buffer was autoclaved before use.

The transfer of RNA from agarose gel onto nylon membrane (Northern blot) was performed according to the method based on capillary forces and described first by Southern (1975). The nylon membrane (pore size $0.45 \mu \mathrm{m}$ ) and the filter papers were equilibrated in $5 \mathrm{x}$ SSC (standard saline citrate) buffer for $5 \mathrm{~min}$. A buffer bridge was built by placing the thick, $12 \mathrm{x}$ $24 \mathrm{~cm}$ filter paper over the glass plate in such a way, that its both ends were submerged in the $20 \mathrm{x}$ SSC solution reservoir. On top of this filter paper the following sandwich was built: 
Top of the sandwich

Thick filter paper

Thin filter paper

Nylon membrane

Gel with gel slots facing the bottom

Thin filter paper

Thick filter paper

Bottom of the sandwich

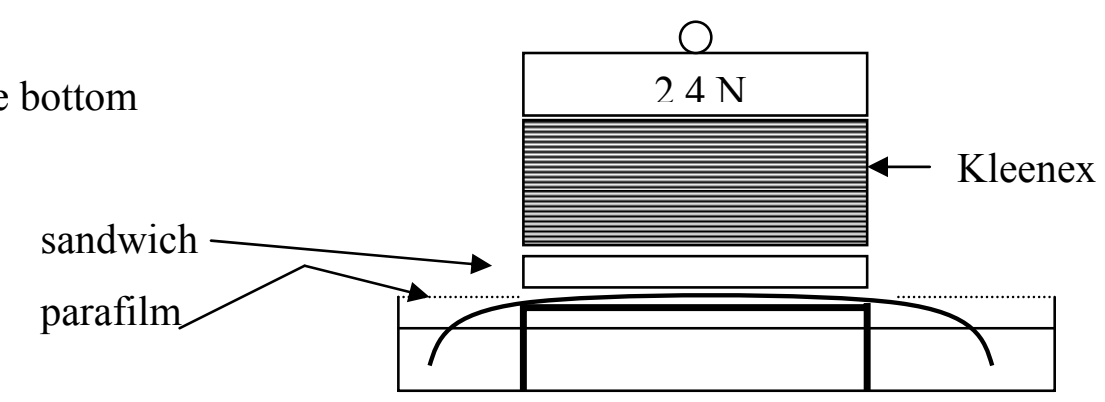

To avoid direct contact of Kleenex tissues with the buffer and thus capillary leakage, the sides of the buffer reservoir were covered with parafilm. Then a $10-15 \mathrm{~cm}$ tall stack of Kleenex paper napkins were placed on the top of the sandwich and the whole stack was subjected to a force of $2.4 \mathrm{~N}$ to facilitate the transfer. At the end of a $16-24 \mathrm{~h}$ transfer both sides of the nylon membrane were exposed to $0.120 \mathrm{~mJ}$ UV light to stably cross-link RNA to the membrane.

The transfer result was documented by photography of the membrane under UV light. The membrane was washed two times with boiling $0.05 \%$ SDS solution (w/v, in autoclaved water) and one or two times with boiling water to get rid of bromphenol blue, ethidium bromide and salts. Afterwards, the membrane was air-dried or directly used for prehybridization.

\subsubsection{Radioactive labeling of oligonucleotides with ${ }^{32} \mathrm{P}$ and Northern blot hybridization}

T4 polynucleotide kinase (T4 PNK), 3'-phosphatase free, was used for radioactive labeling of oligonucleotides by catalyzing the terminal phosphate group $\left[\gamma_{-}{ }^{32} \mathrm{P}\right]$ transfer from ATP to the oligonucleotide 5'-hydroxyl end. The overall labeling volume of $10 \mu$ l contained $50 \mathrm{pmol}$ oligonucleotide $(1 \mu \mathrm{l}$ of $50 \mu \mathrm{M} / \mu \mathrm{l}), 3 \mu \mathrm{l}$ of bidistilled autoclaved water, $1 \mu \mathrm{l}$ of T4 PNK buffer (10 x, final concentration: $10 \mathrm{mM} \mathrm{MgCl}_{2}, 5 \mathrm{mM}$ dithiotreitol, $0.1 \mathrm{mM}$ EDTA, $50 \mathrm{mM}$ 
Tris- $\mathrm{HCl}, 0.1 \mathrm{mM}$ spermidine, $\mathrm{pH} 8.2$ at $25^{\circ} \mathrm{C}$ ), $4 \mu \mathrm{l}$ (equals $\left.1.48 \mathrm{mBq}\right)\left[\gamma^{32} \mathrm{P}\right]$-ATP $(222$ $\mathrm{TBq} / \mathrm{mmol}$ specific activity) and $1 \mu \mathrm{l}$ of T4 PNK (8 I.U./ $\mu \mathrm{l})$. The mixture was incubated at $37^{\circ} \mathrm{C}$ for $1 \mathrm{~h}$ and then $40 \mu \mathrm{l}$ of $100 \mathrm{mM}$ ice-cold EDTA solution were added to stop the reaction. Separation of labeled oligonucleotides from free $\left[\gamma_{-}{ }^{32} \mathrm{P}\right]$-ATP was achieved by subjecting the reaction mixture to filtration through a Micro Spin ${ }^{\mathrm{TM}}$ G-25 column (Amersham, Biosciences) via centrifugation at $735 \mathrm{xg}$ for $2 \mathrm{~min}$. Prior to that the Micro Spin ${ }^{\text {TM }}$ G-25 column was prepared for filtration by mixing and centrifuging at $735 \mathrm{x}$ g for 1 min to allow the column material to settle. The radioactivity of the eluted labeled oligonucleotide was determined to assess the labeling efficiency. After $400 \mu \mathrm{l}$ of herring sperm DNA (stock $10 \mathrm{mg} / \mathrm{ml}$ ) were added, the filtered oligonucleotide solution was transferred to the prehybridization solution of the Northern blot.

The following solutions were required for radioactive hybridization of Northern blots:

$\begin{array}{lll}\text { Denhardt's solution }(100 \mathrm{x}): & 2 \%(\mathrm{w} / \mathrm{v}) & \text { Ficoll }(\mathrm{MW} 400000) \\ & 2 \%(\mathrm{w} / \mathrm{v}) & \text { polyvinyl pyrrolidone } \\ & 2 \%(\mathrm{w} / \mathrm{v}) & \text { bovine serum albumin }\end{array}$

$\begin{array}{lll}\text { Pre-hybridization solution: } & 0.9 \mathrm{M} & \mathrm{NaCl} \\ 0.09 \mathrm{M} & \text { tri-sodium citrate } \\ 12.5 \mathrm{M} & \text { formamide (deionized) } \\ 17 \mathrm{mM} & \mathrm{SDS} \\ 5 \%(\mathrm{v} / \mathrm{v}) & \text { Denhardt's solution }(100 \mathrm{x}) \\ 400 \mu \mathrm{g} / \mathrm{ml} & \text { herring sperm DNA }\end{array}$

Reagents for Denhardt's solution were dissolved in bidistilled water and subjected to filtration trough $5 \mu \mathrm{m}$ and $0.45 \mu \mathrm{m}$ pore size filters. Herring sperm DNA $(10 \mathrm{mg} / \mathrm{ml})$ was sonicated to obtain approximately $500-700 \mathrm{~kb}$ fragments, aliquoted and stored at $-20^{\circ} \mathrm{C}$. Before use, herring sperm DNA was denatured by heating at $95^{\circ} \mathrm{C}$ for $5 \mathrm{~min}$ and chilled on ice.

Unspecific oligonucleotide binding sites on the Northern blots were blocked by prehybridization at $38^{\circ} \mathrm{C}$ for $2-3 \mathrm{~h}$ with pre-hybridization solution under constant shaking conditions. Labeled hybridization probe was added to the pre-hybridization solution and the membrane was hybridized at $38^{\circ} \mathrm{C}$ for $16-24 \mathrm{~h}$ under constant shaking conditions. The 
unspecific bound oligonucleotides were washed off by shaking the blot at $42-70^{\circ} \mathrm{C}$ with wash buffer for $2-5$ min. Several consecutive washing steps with increasing stringency were applied ( $2 \times \mathrm{SSC} / 0.1 \% \mathrm{SDS}, 1 \times \mathrm{SSC} / 0.1 \mathrm{SDS}$ and $0.1 \times \mathrm{SSC} / 0.1 \% \mathrm{SDS}$ ). The wash temperature depended on the oligonucleotide probe used. The radioactivity remaining on the blot was measured after every wash step. Finally, the blot was wrapped into plastic foil and the edges of the wrap were thermo-sealed. $\left[{ }^{32} \mathrm{P}\right]$-sensitive Bio-Imaging-Analyzer films (Fujix) were exposed to the blots within sealed film cassettes for $4-72 \mathrm{~h}$. For quantification of specific bound radioactivity the Bio-Imaging-Analyzer BAS 1500 was used.

\subsubsection{Cell cultures}

\subsubsection{Cultivation of eukaryotic cell lines}

The phosphate buffered saline (PBS), $\mathrm{pH} 7.4$ :

$\begin{array}{ll}136 \mathrm{mM} & \mathrm{NaCl} \\ 2.68 \mathrm{mM} & \mathrm{KCl} \\ 8.2 \mathrm{mM} & \mathrm{Na}_{2} \mathrm{HPO}_{4} \\ 1.47 \mathrm{mM} & \mathrm{KH}_{2} \mathrm{PO}_{4}\end{array}$

PBS was autoclaved before use.

Cell stocks kept in liquid nitrogen were thawed quickly, pipetted into a 10-fold volume of proper medium and cultivated on the $58 \mathrm{~cm}^{2}$ plate (Sarstedt). The medium was changed after $24 \mathrm{~h}$ in order to get rid of DMSO. As soon as the cells reached $95 \%$ confluence, the cells were split and transferred into $75 \mathrm{~cm}^{2}$ flasks. LoVo, HEK293 and TM3 cell lines were cultivated at $37^{\circ} \mathrm{C}$, in the media described previously (chapter 2.1.6.2.1), in an incubator maintaining $5 \% \mathrm{CO}_{2}$ in the atmosphere. The cell lines were split twice per week. The medium from LoVo and TM3 cells was removed, the cells were washed with $6 \mathrm{ml}$ of PBS per $75 \mathrm{~cm}^{2}$ flask and incubated with $2 \mathrm{ml}$ of $2.5 \%$ trypsin/EDTA solution up to $30 \mathrm{~s}$ (TM3) or $4 \mathrm{~min}$ (LoVo), until the cells started to detach. Ten $\mathrm{ml}$ of medium per $75 \mathrm{~cm}^{2}$ flask were added to the cells to stop the trypsin activity. The cell suspension was centrifuged at $113 \mathrm{xg}$ at RT for 5 min. The supernatant was removed and the cell pellet was resuspended in new 
medium, the amount of which depended on the split ratio. The split ratio of TM3 was 1:30 and for the LoVo cells it varied from 1:4 to 1:6. HEK293 cells detached easily, therefore no trypsin/EDTA solution was used and the centrifugation step was not applied. HEK293 cells were detached directly from the $75 \mathrm{~cm}^{2}$ culture flask (Nunc) by pipetting up and down $10 \mathrm{ml}$ of fresh medium and split at ratio of 1:10.

The cell line stocks were generated from the second passage of newly purchased cell lines. The cell pellets from the confluent $75 \mathrm{~cm}^{2}$ flasks were resuspended in $4 \mathrm{ml}$ of the proper medium containing 20\% FCS and 10\% DMSO, aliquoted at $1 \mathrm{ml} /$ tube, frozen step by step as follows: $1 \mathrm{~h}$ at $-20^{\circ} \mathrm{C}, 24 \mathrm{~h}$ at $-80^{\circ} \mathrm{C}$, and stored in liquid nitrogen for several years.

\subsubsection{Cultivation of primary rat hepatocytes}

The hepatocyte suspension, obtained as described in chapter 2.1.5.3, was diluted with MX82 medium containing $10 \%$ of fetal calf serum (chapter 2.1.6.2.2) to a final concentration of $0.5 \times 10^{6}$ cells $/ \mathrm{ml}$, seeded onto $58 \mathrm{~cm}^{2}$ culture plates (Sarstedt) at density of $0.5 \times 10^{6}$ cells/plate and cultivated at $37^{\circ} \mathrm{C}, 10 \% \mathrm{CO}_{2}$ and $90 \%$ air moisture for $2 \mathrm{~h}$. Following attachment of cells, the MX-82 was removed, hepatocytes were washed with sterile PBS and $5 \mathrm{ml}$ of serum-free MX-83 were applied per plate. Cells were further cultured under serumfree conditions, the medium being changed every $24 \mathrm{~h}$. After 4 days of cultivation at the most, hepatocytes were washed with sterile PBS and shock frozen in liquid nitrogen or directly used for total RNA extraction (chapter 2.2.2.4).

\subsubsection{Transfection of mammalian cell lines with expression vectors}

Transfection experiments involving different mammalian cell lines were performed in order to investigate the subcellular localization of rAbcb6 and rAbcb7. Expression vectors (chapter 2.2.8) yielding rAbcb6-EGFP, rAbcb6-DsRed2, rAbcb6-V5, rAbcb7-EGFP, rAbcb7-DsRed2 or rAbcb7-V5 fusion proteins were transiently transfected separately or co-transfected with each other into mammalian cell lines using electroporation (TM3 cells) or according to the protocol of the transfection reagent Fugene 6 (Roche, Mannheim). 


\subsubsection{Electroporation of TM3 cells}

Confluent TM3 cells from a $75 \mathrm{~cm}^{2}$ flask were trypsinized, centrifuged at $113 \mathrm{x} \mathrm{g}$, RT for 5 min and resuspended in $1.5 \mathrm{ml} \mathrm{DMEM} \mathrm{(with} 0.1 \%$ penicillin/streptomycin, $10 \% \mathrm{FCS}, 0.1 \%$ L-glutamine). One hundred $\mu \mathrm{l}$ of the cell suspension were mixed with $1.25 \mu \mathrm{l}$ of DMSO and DNA (the amount of DNA used depended on the plasmid expression level and is indicated in table 9). The mixture was transferred into an electroporation cuvette (Peqlab, Erlangen) with $2 \mathrm{~mm}$ distance between electrodes and electroporated at $500 \mathrm{~V}$, at $200 \Omega$, high capacitance. Ten $\mu$ l of the mixture were distributed on $4 \mathrm{~cm}^{2}$ growth area of Lab-Tek ${ }^{\circledR}$ II Chamber Slide system (Nalgene Nunc, Kamstrup, Denmark) already containing $1 \mathrm{ml}$ of DMEM $+1.25 \%$ DMSO/chamber. The cells were cultured at $37^{\circ} \mathrm{C}, 10 \% \mathrm{CO}_{2}$. Evaluation of protein expression was performed via fluorescence microscopy (chapter 2.2.15.2) $24 \mathrm{~h}, 48 \mathrm{~h}$ and 72 $\mathrm{h}$ after the electroporation.

Table 9. Experimentally determined DNA amounts used per plasmid in co-transfection experiments.

\begin{tabular}{|l|l|l|l|}
\hline & rAbcb6-EGFP & Lamp1-DsRed & Mito-DsRed \\
\hline rAbcb6-EGFP +Mito-DsRed & $10 \mu \mathrm{g}$ & - & $2 \mu \mathrm{g}$ \\
\hline rAbcb6-EGFP+Lamp1-DsRed & $10 \mu \mathrm{g}$ & $10 \mu \mathrm{g}$ & - \\
\hline
\end{tabular}

\subsubsection{Transfection of cell lines with Fugene 6}

For transient transfection with the Fugene 6 (Roche, Mannheim), LoVo or HEK293 cells were plated onto $21 \mathrm{~cm}^{2}$ dishes or onto the $2 \times 4 \mathrm{~cm}^{2}$ growth area of the Lab-Tek ${ }^{\circledR}$ II Chamber Slide system (Nalgene Nunc, Kamstrup, Denmark) $16-24$ hours prior to the transfection. The amount of DNA for transfection of cells plated onto $21 \mathrm{~cm}^{2}$ dishes varied from $1 \mu \mathrm{g}$ to $4 \mu \mathrm{g}$ in total per dish, whereas the amount of DNA meant for the cells plated onto two chamber slides varied from $0.2 \mu \mathrm{g} / \mathrm{plasmid} /$ chamber to $0.8 \mu \mathrm{g} / \mathrm{plasmid} / \mathrm{chamber}$, but did not exceed $1 \mu \mathrm{g} /$ chamber in total. Three $\mu \mathrm{l}$ of Fugene 6 were used per $1 \mu \mathrm{g}$ of plasmid DNA. To the $100 \mu \mathrm{l}$ of FCS-free cell medium an appropriate amount of Fugene 6 
was added and then the plasmid DNA. The mixture was vortexed briefly, incubated at room temperature for $15-45 \mathrm{~min}$ and distributed onto the cells. The development of fluorescence exhibiting proteins was observed via fluorescence microscopy (chapter 2.2.15.2).

\subsubsection{Localization of fusion proteins in the transfected cell lines}

The expression of DsRed2- or EGFP-tagged fusion proteins was observed directly in living or fixed cells via fluorescence microscopy, whereas the V5-tagged rAbcb6 or rAbcb7 proteins were visualized via immunofluorescence.

\subsubsection{Immunofluorescence analysis of cultured cells}

Immunofluorescence was performed on cells plated onto the $2 \times 4 \mathrm{~cm}^{2}$ growth area of the Lab-Tek ${ }^{\circledR}$ II Chamber Slide System (Nalgene Nunc, Kamstrup, Denmark) 48 hours after transfection. The cells were washed twice with $1 \mathrm{ml}$ of PBS/chamber, fixed with $1 \mathrm{ml}$ of 99.8\% methanol/chamber for $5 \mathrm{~min}$ and washed five times with $1 \mathrm{ml}$ of PBS/chamber. The cells were incubated with blocking solution (PBS $+10 \%$ fetal calf serum) for $20 \mathrm{~min}$. The blocking solution was removed and the cells were incubated at room temperature with FITCconjugated antibody against the V5-epitope (Invitrogen), diluted 1:500 in blocking solution for 1 hour in the dark. Specimens were washed twice with PBS (1 ml/chamber), the plastic chamber walls were removed and the cells were mounted with Vectashield medium (Linaris) and a cover slip on top. The last step allowed to observe FITC-dependent fluorescence in upside-down turned specimens via fluorescence microscopy.

\subsubsection{Fluorescence microscopy}

The localization of fluorescent (-EGFP, -DsRed, -DsRed2) fusion proteins was examined via fluorescence microscopy in living and fixed cells of different cell lines on the Axiovert 200 (ZEISS) microscope and documented with an Hamamatsu digital camera C4742-95 via OPENLAB software (Improvision). The excitation and emission maxima of EGFP were at 
$489 \mathrm{~nm}$ and $508 \mathrm{~nm}$, respectively. DsRed2 excitation and emission peaks were $558 \mathrm{~nm}$ and $583 \mathrm{~nm}$, respectively.

Alternatively, the Axiovert TV-100 microscope (Zeiss, Goettingen, Germany) at the Department of Nephrology and Rheumatology, University of Goettingen, was used. The cell fluorescence, seen through this microscope was documented with the digital F-view camera, employing Analysis duku® (Soft-Imaging Systems, Leinfelden/ Echterdingen, Germany) software.

A third fluorescence microscopy system used was an ApoTome microscope (Zeiss, Goettingen, Germany), connected to the AxioCam camera. The documented images were processed with an AxioVision software.

\subsubsection{Biochemical protein analysis}

\subsubsection{Cell fractionation}

The following buffer was used during the cell fractionation:

$\begin{array}{lll}\text { TES + inhibitor buffer }(\mathrm{pH} \mathrm{7.4):} & 20 \mathrm{mM} & \text { Tris } \\ & 1 \mathrm{mM} & \text { EDTA } \\ 254 \mathrm{mM} & \text { saccharose } \\ 2 \mathrm{tabl} / 100 \mathrm{ml} & \text { complete protease inhibitor }\end{array}$

Transfected cells were homogenized and fractionated into fractions enriched in nucleus, mitochondria or plasma membrane and the remaining cytosolic fraction that contained smaller membrane fractions. The fractionation was performed according to the modification of the method described by Simpson et al. (1983). Sixteen confluent $58 \mathrm{~cm}^{2}$ dishes of LoVo or 8 confluent $58 \mathrm{~cm}^{2}$ dishes of HEK293 cells per co-transfection combination were used. The cells were washed $2 \times 2 \mathrm{ml}$ with TES + inhibitor, scraped off the plates with a rubber policeman and collected into a glass potter (Thomas BB 417 - Pistil S 222827). The plates were additionally washed with $50 \mu \mathrm{l}$ of TES + inhibitor buffer and the solution was collected. The collected cell suspension was homogenized $40 \mathrm{x}$ at $1400 \mathrm{RPM}$ with a stir motor. The obtained homogenate was centrifuged at $500 \mathrm{x} \mathrm{g}$ for $10 \mathrm{~min}$ at $4^{\circ} \mathrm{C}$. The pellet contained mostly cell nuclei and was resuspended in TES + inhibitor. The supernatant was 
centrifuged at $10,000 \mathrm{xg}$ for $20 \mathrm{~min}$ at $4^{\circ} \mathrm{C}$ and yielded a mitochondria enriched pellet that was resuspended in TES + inhibitor buffer. The collected supernatant was centrifuged at $18,000 \mathrm{x} \mathrm{g}$ for $35 \mathrm{~min}$ at $4^{\circ} \mathrm{C}$. The pellet, consisting mostly of intracellular organelle membrane fragments lighter than the mitochondria (plasma membrane, lysosomes, endosomes, etc.) was resuspended in TES+inhibitor buffer. The supernatant contained cytosol and lighter membrane fragments. The samples were shock frozen in liquid nitrogen and stored at $-80^{\circ} \mathrm{C}$.

\subsubsection{Determination of protein concentration}

Protein concentrations in fractions enriched in nuclei, mitochondria, plasma membrane fragments or in lighter particles were determined in triplicate according to Lowry et al. (1951). For each determination, $1 \mu \mathrm{l}$ of each fraction was transferred into disposable cuvettes containing $49 \mu \mathrm{l}$ of water. One hundred and fifty $\mu \mathrm{l}$ of $\mathrm{NaOH}(0.1 \mathrm{~N})$ were added per cuvette. The cuvette was shaken carefully and incubated at room temperature (RT) for 10 30 min to dissolve proteins in $\mathrm{NaOH}$. The addition of $1 \mathrm{ml}$ Lowry mix and at least $10 \mathrm{~min}$ incubation afterwards was followed by the addition of $200 \mu \mathrm{l}$ of Folin and Ciocalteu's phenol reagent (Sigma) diluted with the equal volume of water, per cuvette. The samples were mixed immediately and after $30 \mathrm{~min}$ incubation at RT the light absorption at $578 \mathrm{~nm}$ was measured with the BioPhotometer (Eppendorf). For the multiple-point calibration, a row of six standards (2.5 mg, $5 \mathrm{mg}, 10 \mathrm{mg}, 15 \mathrm{mg}, 20 \mathrm{mg}$ and $25 \mathrm{mg}$ of bovine albumin) was prepared for triplicate determination in parallel with other protein samples. Protein pellets, received after fractionation of cell homogenate, were dissolved in TES + inhibitor buffer, which contained Tris and EDTA. Tris and EDTA may influence the protein concentration measurement results, therefore $1 \mu \mathrm{l}$ of TES + inhibitor buffer was added to every standard containing cuvette. The Lowry mix (188.69 $\mathrm{mM} \mathrm{Na}_{2} \mathrm{CO}_{3} / 0.6 \mathrm{mM} \mathrm{CuSO} / \mathrm{m} 0.7 \mathrm{mM}$ potassium-sodium-tartrate) was prepared for every protein determination de novo from stock solutions no. 1,2 and 3 by pipetting them as $50+1+1$.

$\begin{array}{lll}\text { Solution no. } & 2 \%(\mathrm{w} / \mathrm{v}) & \mathrm{Na}_{2} \mathrm{CO}_{3} \text { in } 0.1 \mathrm{~N} \mathrm{NaOH} \\ \text { Solution no. } & 0.5 \%(\mathrm{w} / \mathrm{v}) & \mathrm{CuSO}_{4} \times 4 \mathrm{H}_{2} \mathrm{O} \\ \text { Solution no. } & 1 \%(\mathrm{w} / \mathrm{v}) & \text { potassium-sodium-tartrate }\end{array}$




\subsubsection{Immunoprecipitation}

$\mathrm{NaCl}, \mathrm{mM} \quad$ Hepes, $\mathrm{mM} \quad$ Triton, $\% \quad$ SDS $\quad \mathrm{pH}$

Solubilization buffer

\begin{tabular}{llllll} 
(2 X concentrated) & 300 & 100 & 2 & - & 7.4 \\
Wash buffer I & 10 & 50 & 0.1 & - & 7.4 \\
Wash buffer II & 150 & 50 & 0.1 & - & 7.4 \\
Wash buffer III & 150 & 50 & 0.1 & 0.1 & 7.4 \\
Sepharose buffer & 150 & 50 & - & - & 7.2 \\
\hline
\end{tabular}

All buffers were prepared with bidistilled water and the proper $\mathrm{pH}$ was adjusted with $32 \%$ $\mathrm{HCl}$. Seventy five mg of protein-A-sepharose CL-4B (Pharmacia) were gently mixed with 1 $\mathrm{ml}$ of sepharose buffer at least $24 \mathrm{~h}$ prior to the experiment for sepharose beads to swell at $4^{\circ} \mathrm{C}$, and stored at $4^{\circ} \mathrm{C}$ for up to six months. Before use, a complete protease inhibitor was added to the proper volume of solubilization buffer (final concentration $2.4 \mu \mathrm{g} / \mu \mathrm{l}$ in $2 \mathrm{x}$ concentrated solubilization buffer).

Cell membranes were solubilized by adding a volume of solubilization buffer equal to the volume of the subcellular fraction, containing $0.2-1 \mathrm{mg}$ of proteins. The mixture was incubated on ice under gentle shaking for $30 \mathrm{~min}$ to $1 \mathrm{~h}$ and centrifuged in a pre-chilled centrifuge at $20,000 \times \mathrm{g}$ for $45 \mathrm{~min}$ at $4^{\circ} \mathrm{C}$. The supernatant was incubated with antibody against full-length GFP (cross-reactive with EGFP) or the V5 tag (dilution 1:50) or with preimmune serum (dilution 1:100) for $1 \mathrm{~h}$ shaking on ice. The formed antigen-antibody complex was precipitated on ice with $50 \mu \mathrm{l}$ of protein A sepharose suspension for $1 \mathrm{~h}$. Sepharose beads were shaken by hand every $10 \mathrm{~min}$. The sample was shortly centrifuged and the supernatant was discharged. The beads were washed $3 \mathrm{x}$ with $0.75 \mathrm{ml}$ of wash buffer I, $2 \mathrm{x}$ with $0.75 \mathrm{ml}$ of wash buffer II and in case of immunoprecipitation of TM3 cell fractions were washed once with $0.75 \mathrm{ml}$ of wash buffer III. Elution of antigen-antibody complex was 
performed via gentle mixing of the beads with $15 \mu$ of Laemmli buffer containing DTT (chapter 2.2.16.4.2). The sample was incubated at $95^{\circ} \mathrm{C}$ for $5 \mathrm{~min}$, briefly centrifuged and the supernatant containing the antigen-antibody complex was collected into the new tube. The elution procedure was performed twice and the total $30 \mu \mathrm{l}$ of supernatant volume per sample was transferred into the SDS polyacrylamide gel slot or stored at $-20^{\circ} \mathrm{C}$ for up to three days.

\subsubsection{Separation of proteins via SDS polyacrylamide gel electrophoresis}

For the immunochemical detection of proteins in Western blots the proteins were separated on the basis of their molecular mass under denaturating conditions of SDS polyacrylamide gel electrophoresis according to Laemmli et al. (1970). A non-continuous vertical gel electrophoresis system consisting of a separating and concentrating gel, was used. Depending on the expected size of the protein of interest, the percentage of acrylamide in the protein separating gel varied between $7.5 \%$ and $12 \%$. The concentrating gel part contained $3.9 \%$ of acrylamide, independent of the protein size. The concentrating gel was cast on top of the separating gel.

\subsection{Preparation of vertical SDS polyacrylamide gels}

For preparation of vertical SDS polyacrylamide gels the following buffers were used:

\begin{tabular}{|c|c|}
\hline Buffer for separating gel & $1.5 \mathrm{M}$ \\
\hline (pH 8.8): & $14 \mathrm{mM}$ \\
\hline Buffer for concentrating gel & $0.5 \mathrm{M}$ \\
\hline (pH 6.8): & $14 \mathrm{mM}$ \\
\hline
\end{tabular}

Acrylamide stock solution (29:1) $\quad 4.1 \mathrm{M} \quad$ acrylamide

$0.65 \mathrm{M} \quad \mathrm{N}, \mathrm{N}$ '-methylene bisacrylamide 
The $\mathrm{pH}$ value of protein collecting and separating gel buffers was adjusted with $1 \mathrm{~N} \mathrm{HCl}$. Solutions were stored at $4{ }^{\circ} \mathrm{C}$ for up to six months. Ammonium persulfate solution was freshly prepared before every experiment in bidistilled water at $0.5 \mathrm{mg} / \mu \mathrm{l}$.

SDS polyacrylamide gels were cast within the "Mighty Small SE Dual Gel Caster". Two sizes of glass plates were used for the gel chamber: $83 \times 101 \mathrm{~mm}$ and $83 \times 124 \mathrm{~mm}$. The gel thickness was $1 \mathrm{~mm}$ in both cases. The protein separating gel solution was made up by mixing solutions listed in a table below. Since the addition of N,N,N',N'tetramethylethylenediamine (TEMED) initiates the polymerization reaction, the TEMED was added before pouring the mixture into the chamber. The $0.5 \%$ SDS solution was poured onto the top to assure homogeneous polymerization and a straight upper lane formation of the protein separating gel. Two hours later, the polymerized protein separating gel covered with $0.5 \%$ SDS solution was transferred to $4{ }^{\circ} \mathrm{C}$ for over night storage.

Glass plate measurements, $\mathrm{mm}$

$83 \times 101$

$83 \times 124$

Protein separating gel

$7.5 \%$

$10 \%$

$12 \%$

$7.5 \%$

\begin{tabular}{lllll} 
Separating gel buffer & $1.56 \mathrm{ml}$ & $1.56 \mathrm{ml}$ & $1.56 \mathrm{ml}$ & $1.72 \mathrm{ml}$ \\
Bidistilled water & $2.94 \mathrm{ml}$ & $2.44 \mathrm{ml}$ & $2.04 \mathrm{ml}$ & $3,23 \mathrm{ml}$ \\
Acrylamide solution $29 / 1$ & $1.50 \mathrm{ml}$ & $2.00 \mathrm{ml}$ & $2.40 \mathrm{ml}$ & $1.65 \mathrm{ml}$ \\
Ammonium persulfate $(0.5 \mathrm{mg} / \mu \mathrm{l})$ & $12 \mu \mathrm{l}$ & $12 \mu \mathrm{l}$ & $12 \mu \mathrm{l}$ & $13.2 \mu \mathrm{l}$ \\
TEMED & $6 \mu \mathrm{l}$ & $6 \mu \mathrm{l}$ & $6 \mu \mathrm{l}$ & $6.6 \mu \mathrm{l}$ \\
\hline
\end{tabular}

The SDS solution was removed at RT and the upper part of the gel chamber was washed twice with buffer for the concentrating gel. The gel solution for the concentrating gel was made up by mixing solutions indicated in the table below. The mixture was poured into the chamber on top of the polymerized protein separating gel. The comb for the gel slot formation was inserted carefully, avoiding the trapping of air bubbles. The concentrating gel polymerized at room temperature for $1 \mathrm{~h}$. 
Concentrating gel $\quad 3.9 \%$

Concentrating gel buffer $\quad 520 \mu 1$

Bidistilled water $\quad 1.22 \mathrm{ml}$

Acrylamide solution 29/1 $260 \mu \mathrm{l}$

Ammonium persulfate $(0.5 \mathrm{mg} / \mu \mathrm{l}) \quad 4 \mu \mathrm{l}$

TEMED $\quad 2 \mu 1$

\subsection{Preparation of protein samples}

The following buffer was used for the preparation of protein samples:

Laemmli sample buffer (LSB) 2 x

$\begin{array}{ll}119 \mathrm{mM} & \text { Tris } \\ 4.76 \mathrm{mM} & \text { EDTA } \\ 132 \mathrm{mM} & \text { SDS } \\ 2.59 \mathrm{M} & \text { glycerol } \\ 0.0476 \%(\mathrm{w} / \mathrm{v}) & \text { bromphenol blue }\end{array}$

The LSB $2 \mathrm{x}$ was aliquoted into $1 \mathrm{ml}$ portions and stored at $-20^{\circ} \mathrm{C}$. Before use, $3 \%(\mathrm{w} / \mathrm{v})$ of dithiothreitol (DTT) was added to the required amount of buffer.

Ten to $150 \mu \mathrm{g}$ of protein were loaded per gel pocket. The volume of samples was adjusted with TES + inhibitor buffer (chapter 2.2.16.1) to the largest one required for the determined amount of proteins to be loaded. The samples were mixed with $2 \times$ LSB or with $4 \times$ LSB to obtain the final concentration of $1 \mathrm{x}$ LSB. The samples were incubated at $95^{\circ} \mathrm{C}$ for 2 to 5 min, chilled on ice for $15 \mathrm{~s}$, centrifuged briefly and loaded into the slots of polyacrylamide gel at RT. The molecular weight marker SDS-6H (Sigma) was prepared in the same way as the samples were. The Color Burst protein marker was delivered as ready-to-use, therefore no additional preparation was required prior to loading to the gel slots. 


\subsection{Electrophoresis}

$\begin{array}{lll}\text { Electrophoresis buffer } 8 \times(\mathrm{pH} 8.4): & 0.2 \mathrm{M} & \text { Tris } \\ & 1.54 \mathrm{M} & \text { glycine } \\ & 0.1 \%(\mathrm{w} / \mathrm{v}) & \text { SDS }\end{array}$

Chemicals were dissolved in bidistilled water and the $8 \mathrm{x}$ concentrated buffer was stored at $4^{\circ} \mathrm{C}$.

The electrophoresis was performed under chilling conditions in the "Mighty Small II" vertical electrophoresis chamber. After the chamber had been filled with the electrophoresis buffer, samples were loaded into the gel slots with "Gel Saver Spikes" pipette tips and run through the concentrating gel at $10 \mathrm{~mA} /$ gel within approximately $1 \mathrm{~h}$. The current was then increased to $20 \mathrm{~mA} / \mathrm{gel}$ and the protein samples separated through the protein separating gel in $2-4 \mathrm{~h}$, depending on the gel length. The electrophoresis was stopped as soon as the blue bromphenol line had reached the bottom of the gel.

\subsubsection{Detection of proteins in Western blot}

Proteins, separated from one another according to their molecular weight during SDS polyacrylamide gel electrophoresis, were immobilized onto polyvinylidene difluoride (PVDF) membrane to make the proteins available for immunological analysis (Western blot). 


\subsection{Semi-dry transfer of proteins}

$\begin{array}{lll}\text { Transfer buffer }(\mathrm{pH} 9.0): & 48 \mathrm{mM} & \text { Tris } \\ & 39 \mathrm{mM} & \text { glycine } \\ & 1.3 \mathrm{mM} & \text { SDS } \\ & 15 \%(\mathrm{v} / \mathrm{v}) & \text { methanol }\end{array}$

Protein transfer from the gel onto PVDF membrane was performed according to KyhseAndersen (1984), except that a continuous buffer system was used. The semi-dry transfer chamber had a high-grade steal cathode and a glass/graphite anode.

At the end of electrophoresis, the protein separating gel was separated by scalpel from the collecting one and equilibrated in the transfer buffer at RT for $20 \mathrm{~min}$. The PVDF membrane was activated in methanol for $10 \mathrm{~s}$, washed with bidistilled water twice and equilibrated in transfer buffer for $10 \mathrm{~min}$. Nine thick and 2 thin filter papers, sized $5.2 \times 8.3$ or $7.5 \times 8.3 \mathrm{~cm}$, were soaked in the transfer buffer. After moistening of the electrodes with bidistilled water, the "transfer sandwich" was put together as follows:

Anode $(+)$ top

6 thick filter papers

1 thin filter paper

PVDF membrane

Polyacrylamide gel

1 thin filter paper

3 thick filter papers

Cathode (-) bottom

The air bubbles between the layers were removed with a rubber roll. The transfer was performed at room temperature for $1.5-2 \mathrm{~h}$ under a current of $0.8 \mathrm{~mA} / \mathrm{cm}^{2}$ (approximately 40 or $50 \mathrm{~mA} / \mathrm{gel}$, depending on the size of the gel). 


\subsection{Stainings and preservation of the gel}

Solutions used for stainings and preservation of the gel:

Ponceau-S dye solution:

Coomassie brilliant blue stock solution: $\quad 1 \%(\mathrm{w} / \mathrm{v}) \quad$ Coomassie brilliant blue R 250

$5 \%(\mathrm{v} / \mathrm{v}) \quad$ methanol

$50 \%(\mathrm{w} / \mathrm{v}) \quad$ trichloracetic acid

Distaining solution:

Gel shrinking solution:

$$
\begin{array}{ll}
0.25 \%(\mathrm{w} / \mathrm{v}) & \text { Ponceau-S } \\
40 \%(\mathrm{v} / \mathrm{v}) & \text { methanol } \\
15 \%(\mathrm{v} / \mathrm{v}) & \text { pure acetic acid }
\end{array}
$$

$10 \%(\mathrm{v} / \mathrm{v}) \quad$ methanol

$7.6 \%(\mathrm{v} / \mathrm{v}) \quad$ pure acetic acid

$\begin{array}{ll}2 \%(\mathrm{w} / \mathrm{v}) & \text { glycerol } \\ 55 \%(\mathrm{v} / \mathrm{v}) & \text { methanol }\end{array}$

The Coomassie brilliant blue working solution was made by diluting the stock solution with $50 \%(\mathrm{w} / \mathrm{v})$ trichloracetic acid at a ratio of 1:7 and was used for more than one time. Both staining solutions were filtered before use and stored at room temperature.

At the end of transfer, the PVDF membrane part containing the molecular weight marker SDS-6H was cut off from the rest of the membrane and stained for $1 \mathrm{~min}$ in Ponceau $\mathrm{S}$ solution. The standard containing membrane was rinsed with bidistilled water to reduce the background. The red labeled bands of the standard were used as a reference for the determination of molecular weight of protein bands. To verify transfer efficiency and homogeneity, the gel was stained with the Coomassie brilliant blue solution for up to $1 \mathrm{~h}$. To reduce the background, the gel was rinsed with distaining solution. Then the gel was incubated in the shrinking solution for $4 \mathrm{~h}$ and dried between two stretched plastic foils to preserve it for documentation. The PVDF membrane was washed 2 × 5 min with bidistilled water and either air-dried for later usage or used at once for the immune reaction. 


\subsection{Immunochemical detection of the protein of interest}

Buffers used for the immunochemical detection of the protein of interest:

$\begin{array}{lll}\text { Wash buffer A (pH 7.4): } & 10 \mathrm{mM} & \text { Tris } \\ & 154 \mathrm{mM} & \mathrm{NaCl}\end{array}$

Wash buffer B (pH 7.0): $\quad 154 \mathrm{mM} \quad \mathrm{NaCl}$

$\begin{array}{ll}7 \mathrm{mM} & \text { SDS } \\ 0.5 \%(\mathrm{w} / \mathrm{v}) & \text { Triton X } 100 \\ 0.5 \%(\mathrm{w} / \mathrm{v}) & \text { bovine serum albumin }\end{array}$

Wash buffer C: $\quad$ buffer A with

$0.5 \%(\mathrm{w} / \mathrm{v}) \quad$ Tween 20

The PVDF membrane was incubated at RT for $4 \mathrm{~h}$ with wash buffer $\mathrm{C}$ containing $5 \%$ of nonfat milk powder (Applichem) under gentle agitation to block the unspecific protein binding sites. The membrane was washed $3 \times 5$ min with buffer $\mathrm{C}$ and incubated with primary antibody diluted in the range of 1:1000 to $1: 5000$ in buffer $C$ with $1-2.5 \%$ milk powder. Depending on the antibody, the membrane was incubated for $1-3 \mathrm{~h}$ at RT or over night at $4^{\circ} \mathrm{C}$ under constant shaking. If the membrane was incubated with monoclonal antibody, the membrane was washed for $6 \times 5$ min with buffer A. After membrane incubation with polyclonal antibody, it was washed first $2 \times 5$ min with buffer A, then $2 \times 5$ min with buffer $\mathrm{B}$ and again $2 \times 5$ min with buffer A. In case the primary antibody was conjugated with HRP (horseradish peroxidase), the PVDF membrane was directly subjected to the ECL (enhanced chemiluminescence) reaction. The membrane was carefully dried from residual moisture and transferred at once to the prepared ECL substrate solution. ECL substrate solution was prepared by mixing equal parts $(1.5 \mathrm{ml}$ or $5 \mathrm{ml}$, depending on the size of the membrane $)$ of the stable peroxide solution and the luminol/enhancer solution just before subjecting the membrane to light-sensitive films. The blot was incubated in ECL working solution for 5 min at RT, being shaken by hand. Surplus substrate solution was absorbed by filter paper and the moist membrane was sealed into plastic foil. The substrate transformation during reaction with HRP resulted in chemiluminescence in the areas of membrane, where the antigen- 
antibody complex was formed. The chemiluminescence was detected via membrane exposure to light-sensitive film in an autoradiography cassette at RT. The incubation of the PVDF membrane with the film varied from $1 \mathrm{~s}$ to over night. If the primary antibody was not HRP-conjugated, an incubation of PVDF membrane with secondary antibody was necessary. After $1.5-3 \mathrm{~h}$ incubation with secondary, HRP-conjugated antibody, the PVDF membrane was washed in the same way as after the incubation with the primary antibody and subjected to the immune complex visualization via ECL reaction as described above.

For the re-development of a PVDF membrane with a new primary antibody, the PVDF membrane was stripped for $3 \times 5$ min with $0.1 \mathrm{M}$ glycine solution ( $\mathrm{pH} 2.5)$ to dissolve the antibody-antigen complex, washed 3 x 5 min with bidistilled water and 3 x 5 min with buffer A and exposed to the new primary antibody. Glycine solution was prepared as $1 \mathrm{M}$ stock solution $(\mathrm{pH}$ was adjusted with $32 \% \mathrm{HCl})$ and stored at $4{ }^{\circ} \mathrm{C}$. The working solution $(1: 10$ diluted stock solution with bidistilled water) was stored at room temperature. 


\section{Results}

\subsection{Cloning of $\mathrm{rAbcb7}$ and re-cloning of rAbcb6}

Rat $\mathrm{rAbcb6}$ is a recently identified $\mathrm{ABC}$ half-transporter which might participate in biometal homeostasis (Hirsch-Ernst et al. 1998). At the beginning of the work for this thesis the identity of the exact dimerization partner of rAbcb6 was unknown. In the literature, a functional complementation of defective Atm1p by the related human proteins ABCB6 (Mitsuhashi et al. 2000) and ABCB7 (Csere et al. 1998) had been described. This gave rise to the idea of possible heterodimerization of the corresponding rat half transporters $\mathrm{rAbcb} 6$ with $\mathrm{rAbcb} 7$, assuming that the rat orthologue to human $\mathrm{ABCB} 7$ existed and was present in the same system. To investigate a possible interaction between rAbcb6 and rAbcb7 via construction of expression vectors for both proteins, the cDNA sequences of both genes were required. rAbcb6 cDNA had been cloned before, but the rAbcb7 cDNA at the beginning of this work was unknown. Therefore rat rAbcb7 cDNA was cloned.

\subsubsection{Cloning of $\mathrm{rAbcb7}$}

The NCBI data bank research revealed two experimentally derived rat EST sequences: CB 556380 and AI 072132, that aligned to the 5'- and 3'-end of human ABCB7 (accession number NM 004299), respectively (fig. 3). CB 556380 was experimentally found in rat hypothalamus, whereas the sequence AI 072132 was derived from the UI-R-C0 library that consisted of a mixture of individually tagged normalized libraries constructed from various rat organs. On the basis of the alignment, RT-PCR primers were constructed to investigate whether rAbcb7 mRNA was expressed in rat hepatocytes (fig. 3). The sequence-specific primers $\mathrm{B} 7 \mathrm{~F} 1$ and $\mathrm{B} 7 \mathrm{R} 1$ were designed and used for an RT-PCR application (chapter 2.2.7.2). Total RNA extracted from primary rat hepatocytes (chapter 2.2.2.4.1.1), cultured for 4 days, was used as a template. The exact length of the expected fragment was $584 \mathrm{bp}$. The RT-PCR yielded a fragment of approximately $600 \mathrm{bp}$, confirming the existence of rAbcb7 mRNA in rat hepatocytes (fig. 4). 

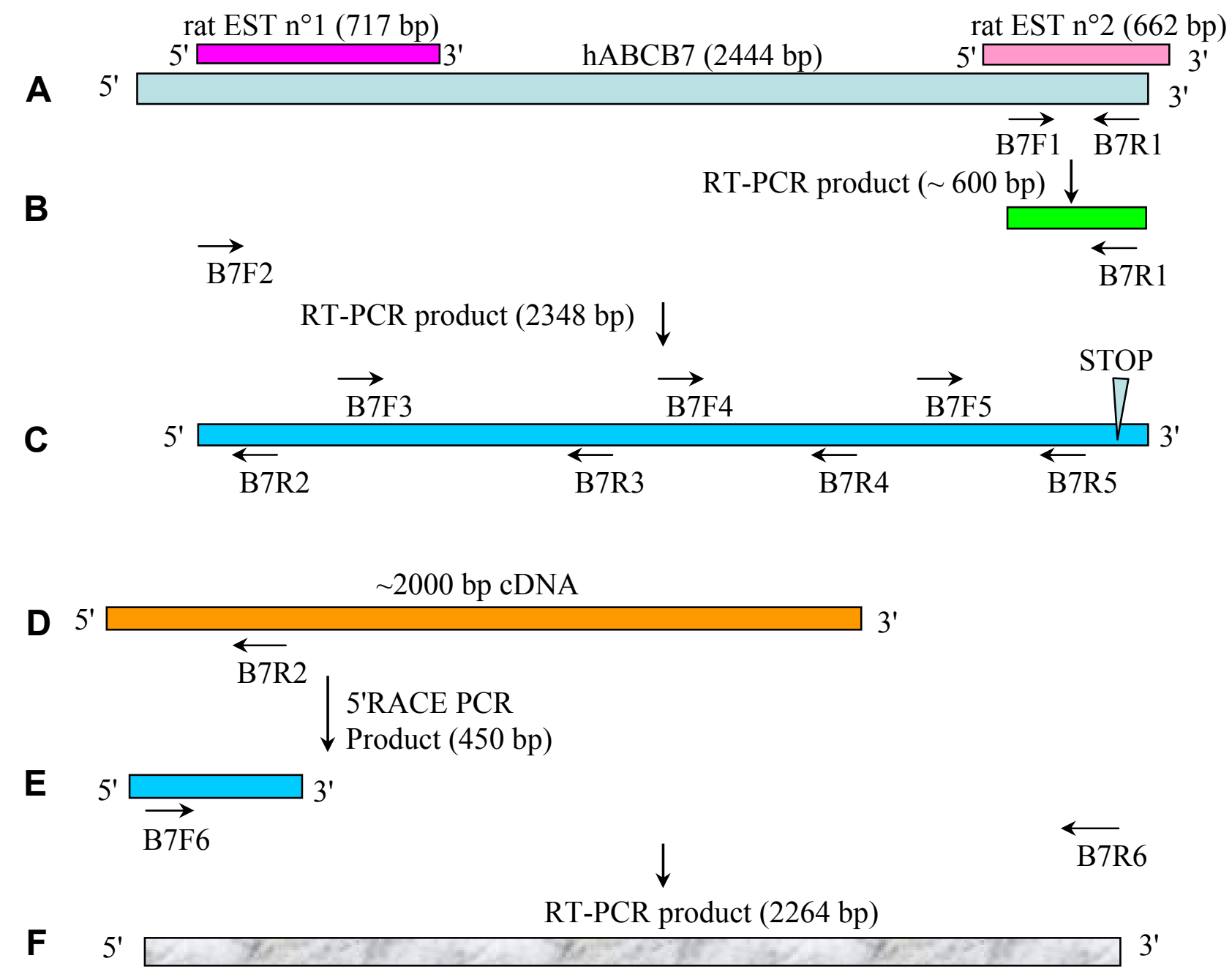

Assembly of $\mathrm{C}$ and E sequences $\downarrow$

rAbcb7 sequence (2368 bp), deposited at EMBL database

(accession number is AJ621255)

G $\quad 5^{\prime}$

Figure 3. Cloning strategy of rat Abcb7 cDNA. Forward and reverse primers B7F1, B7R1 and $\mathrm{B} 7 \mathrm{~F} 2$ for the rat $\mathrm{Abcb} 7 \mathrm{cDNA}$ sequence were designed on the basis of the alignment obtained with the Homo sapiens ABCB7 (accession number NM 004299), Rattus norvegicus EST $n^{\circ} 1$ (CB 556380) and EST $n^{\circ} 2$ (AI 072132) sequences (A). A fragment of approximately 600 bp received via RT-PCR with B7F1 and B7R1 primers, confirmed rAbcb7 expression in rat hepatocytes (B). The 2348 bp RT-PCR product from B7F2 and B7R1 primers was sequenced via primer walking (C). The cDNA obtained via reverse transcription with primer B7R4 (D) was used for 5'RACE PCR. The 5'RACE PCR with B7R2 and oligo dT-anchor (Roche) primers extended the rAbcb7 cDNA sequence to the 5'end by $20 \mathrm{bp}(\mathrm{E})$. The $2368 \mathrm{bp}$ rAbcb7 sequence was assembled from $\mathrm{C}$ and $\mathrm{E}$ sequences and deposited in EMBL database (accession number AJ621255). The cDNA sequence obtained 
via RT-PCR from B7F6 and B7R6 primers (F) confirmed the coding part of the assembled sequence $(\mathrm{G})$. The latter RT-PCR outcome was designed for cloning into expression vectors and therefore the cDNA ended at the 3 '-end before the first stop codon.

The following RT-PCR with primers B7F2 and B7R1 yielded a cDNA band of about $2.3 \mathrm{~kb}$, that was cloned and sequenced via primer walking (fig. 3) with B7F3, B7F4, B7F5, B7R2, B7R3, B7R4 and B7R5 primers (chapter 2.1.7.3) as described in chapter 2.2.9. The obtained sequence was confirmed by sequencing 10 independent clones. Overlaps between sequenced fragments were $100-300 \mathrm{bp}$ long. Alignment of $\mathrm{rAbcb} 7 \mathrm{cDNA}$ sequencing results with the human $\mathrm{ABCB} 7 \mathrm{cDNA}$ sequence showed that the 5'-end of the human sequence was longer than the rat one. Therefore the rat $\mathrm{rAbcb} 7 \mathrm{mRNA}$ was expected to be longer at the 5'-end than the sequenced cDNA. Performed 5'RACE PCR (chapter 2.2.7.3) yielded a $450 \mathrm{bp}$ product that was cloned and sequenced as described in chapter 2.2.9. Analysis of sequencing results with the CLUSTAL W (EBI) programme revealed that the 5'RACE PCR resulted in a 20 bp elongation of the rAbcb7 cDNA. The rAbcb7 cDNA sequence was in total $2368 \mathrm{bp}$ long and deposited in the EMBL database under the accession number AJ621255. The coding part of the rAbcb7 cDNA was confirmed experimentally via RT-PCR with B7F6 and B7R6 primers (chapter 2.1.7.3) that yielded a 2264 bp long cDNA sequence due to B7R6 primer positioning at the 3 ' end before the first stop codon. The obtained rAbcb7 cDNA was sequenced with primers designed via primer walking. Overlaps between sequenced fragments were 300 - 500 bp long. The received $\mathrm{rAbcb} 7 \mathrm{cDNA}$ sequence was confirmed by sequencing 5 independent clones. The outline of the rAbcb7 cloning strategy is shown in fig. 3.

Alignment of the received 2368 bp long rAbcb7 cDNA sequence with human ABCB7 cDNA revealed that the first methionine of $\mathrm{rAbcb} 7$ corresponded to the first methionine of the human sequence (fig. 5). This fact allowed to assume that the experimentally received rAbcb7 cDNA sequence translated into the amino acids sequence represented the full open reading frame. However, a stop codon 5' of the first methionine was not detected in the rAbcb7 cDNA sequence. Therefore, it cannot be ruled out that the full rAbcb7 mRNA could be longer than the received cDNA. 


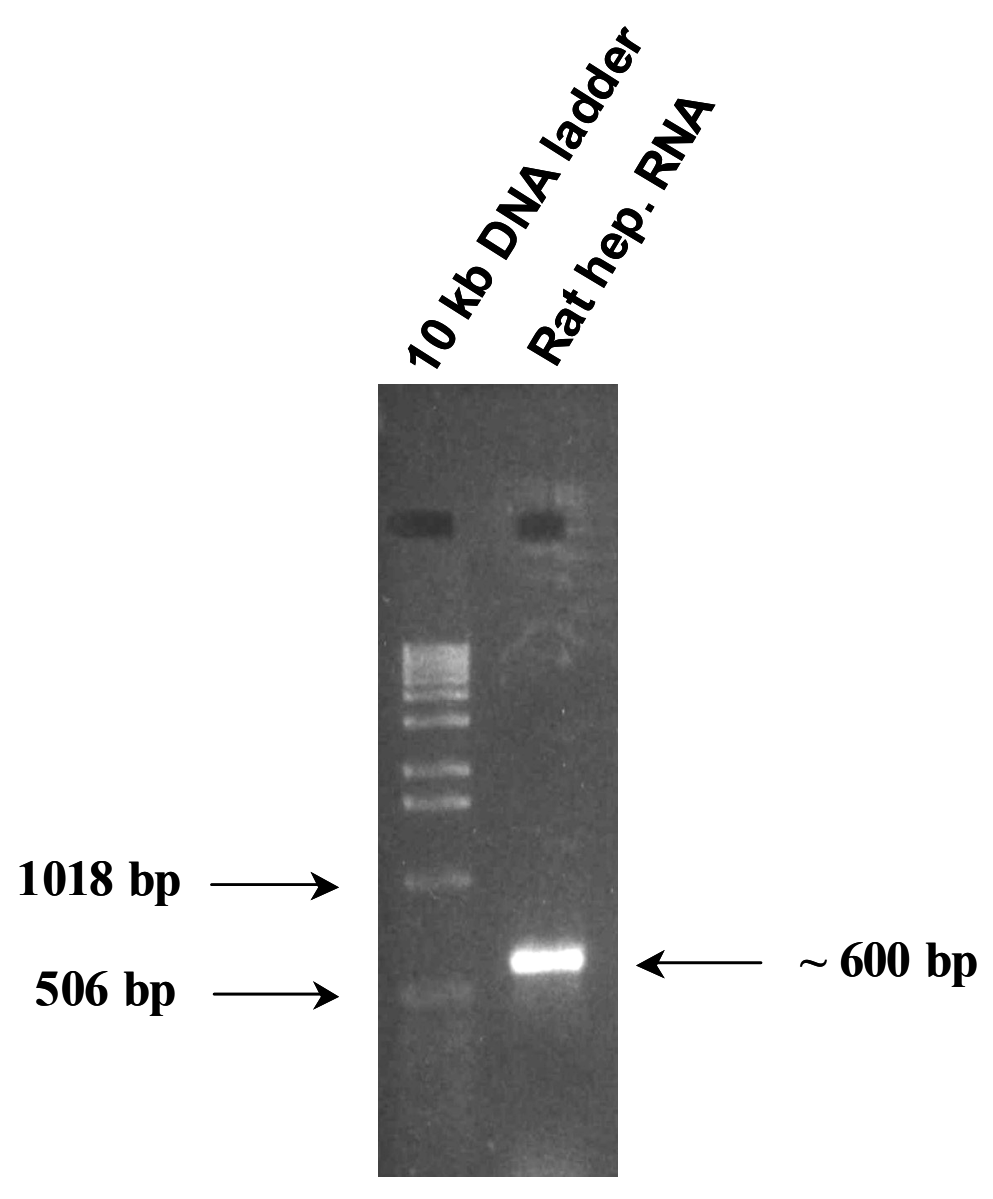

Figure 4. Confirmation of rat Abcb7 (rAbcb7) mRNA expression in rat hepatocytes. The approximately $600 \mathrm{bp}$ long rAbcb7 cDNA fragment was obtained by means of RT-PCR from the rat hepatocyte total RNA. 
Figure 5. the 5'-end alignment of rAbcb7 and human hABCB7 cDNAs. Stop codon (stop) and first methionine (M) encoding nucleotide triplets are marked in frames.

The $2256 \mathrm{bp}$ open reading frame of the experimentally received rAbcb7 encoding cDNA sequence was expected to result in a 752 amino acid long protein (fig. 6). The deduced protein sequence consisted of one transmembrane and one ATP-binding domain. The ATPbinding cassette (ABC) contained the Walker A (GSGKST), signature (LSGGE) and Walker B (DEAT) motifs (fig. 6). The calculated mass of rAbcb7 protein was $82.72 \mathrm{kDa}$.

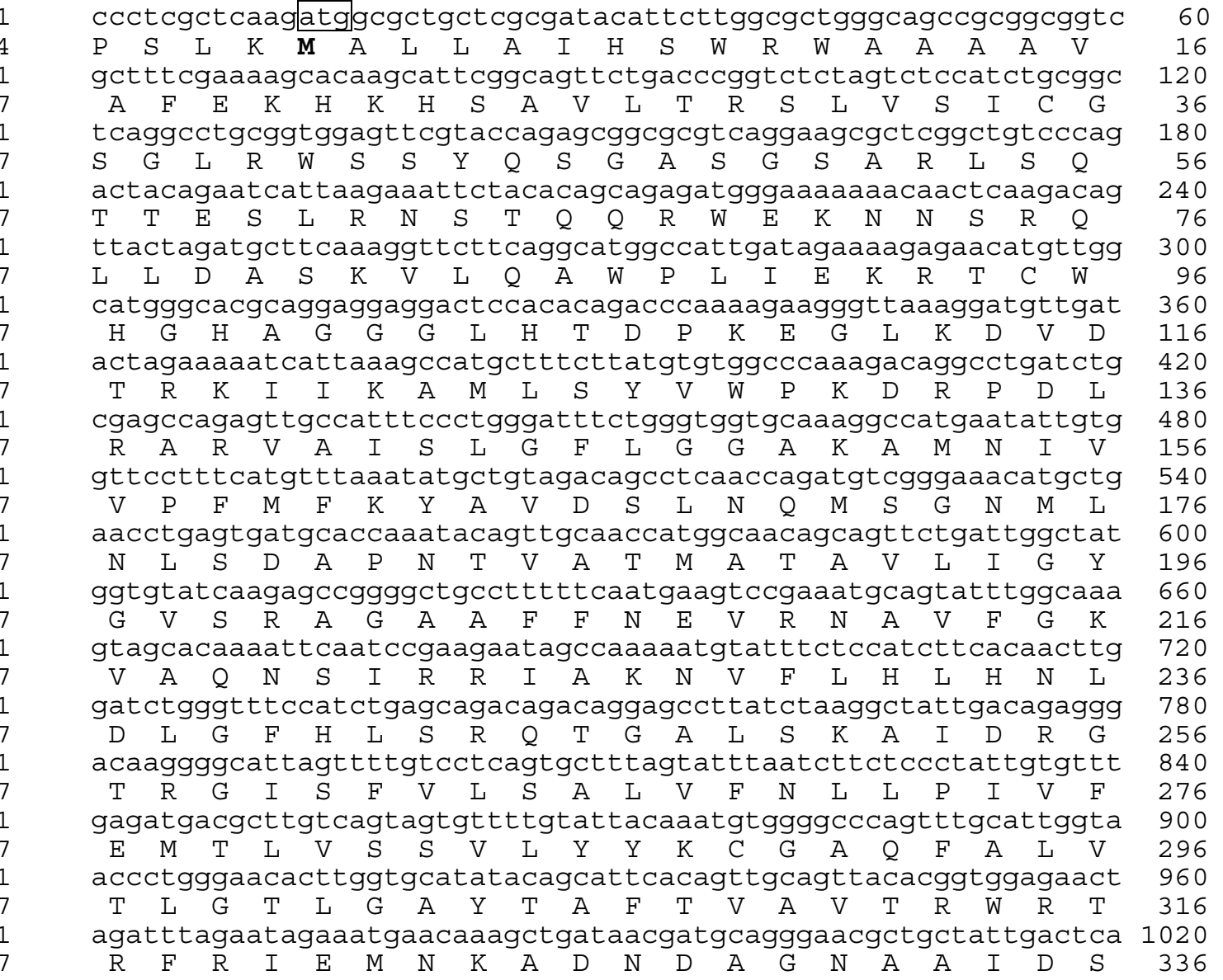



gatggattcttgaagacatatgagactgcttcattgaaaagtacctctactctggctatg 1140

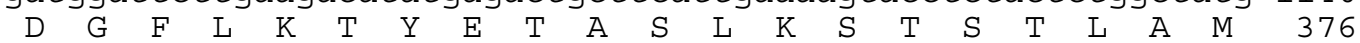
ctgaattttggccaaagtgctattttcagtgttggattaacagctatcatggtgcttgcC 1200 $\begin{array}{lllllllllllllllllllllll} & \mathrm{N} & \mathrm{F} & \mathrm{G} & \mathrm{Q} & \mathrm{S} & \mathrm{A} & \mathrm{I} & \mathrm{F} & \mathrm{S} & \mathrm{V} & \mathrm{G} & \mathrm{L} & \mathrm{T} & \mathrm{A} & \mathrm{I} & \mathrm{M} & \mathrm{V} & \mathrm{L} & \mathrm{A} & 396\end{array}$ agtcagggaattgtggcaggtgcccttactgttggagatctagtaatggtgaatggactg 1260 $\begin{array}{llllllllllllllllllllllllllll}S & Q & G & I & V & A & G & A & L & T & V & G & D & L & V & M & V & N & G & L & 416\end{array}$ cttttcaacttcattaccccttaacttcttgggaactgtatatagagagacacggcaa 1320 $\begin{array}{lllllllllllllllllllll}\mathrm{L} & \mathrm{F} & \mathrm{Q} & \mathrm{L} & \mathrm{S} & \mathrm{L} & \mathrm{P} & \mathrm{L} & \mathrm{N} & \mathrm{F} & \mathrm{L} & \mathrm{G} & \mathrm{T} & \mathrm{V} & \mathrm{Y} & \mathrm{R} & \mathrm{E} & \mathrm{T} & \mathrm{R} & \mathrm{Q} & 436\end{array}$ gcactcatagatatgaataccttgtttactctgctcaaggtagacacgcggattaaagac 1380

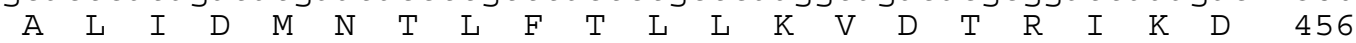
aaagcgatggcatctccccttcaataacaccacagacagccacggtggcctttgataat 1440 $\begin{array}{lllllllllllllllllllll}K & A & M & A & S & P & L & Q & I & T & P & Q & T & A & T & V & A & F & D & N & 476\end{array}$ gtgcattttgagtacattgaaggacagaaagtccttagcggagtatcttttgaagtccct 1500

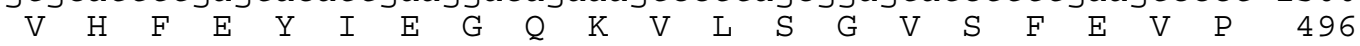
gcaggaaagaaagtggccattgtaggaggtagtgggtcaggaaaaagcacgatagtgagg 1560

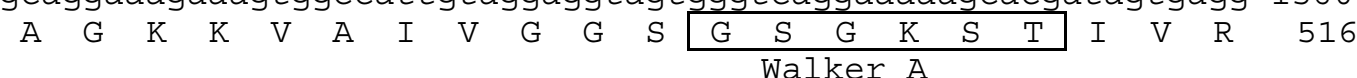
ctgctgtttcgcttctatgagcctcaaaagggtagcatttaccttgctggtcaaaatatt 1620

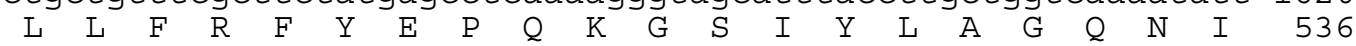
caagatgtgagcctggaaagtcttcggcgtgcagtgggagtagtacctcaggatgctgtc 1680 $\mathrm{Q}$ D V S L E S L R R A V G V V P Q D A V 556 ctctccataatactatctactacaacctcttatatggaaacatcaatgcgtcaccagag 1740 $\begin{array}{llllllllllllllllllllll}\mathrm{L} & \mathrm{F} & \mathrm{H} & \mathrm{N} & \mathrm{T} & \mathrm{I} & \mathrm{Y} & \mathrm{Y} & \mathrm{N} & \mathrm{L} & \mathrm{L} & \mathrm{Y} & \mathrm{G} & \mathrm{N} & \mathrm{I} & \mathrm{N} & \mathrm{A} & \mathrm{S} & \mathrm{P} & \mathrm{E} & 576\end{array}$ gaagtatatgcagtcgcaaattggctggtcttcatgatgcaattcttcgaatgccacat 1800

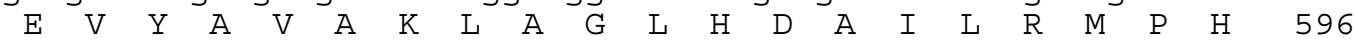
ggatatgacacacaagtaggagaacgaggactcaagttatcaggaggagaaaagcagagg 1860

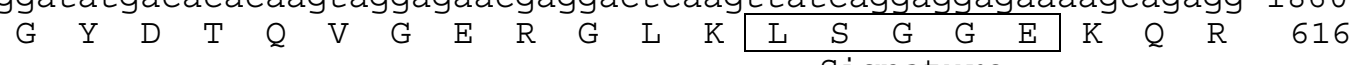
Signature
gtagcgattgcaagagccattttgaaggatcccccagttattctctatgatgaagctact 1920 \begin{tabular}{llllllllllllllll|lllll}
$V$ & $A$ & $I$ & $A$ & $R$ & $A$ & $I$ & $L$ & $K$ & $D$ & $P$ & $P$ & $V$ & $I$ & $L$ & $Y$ & $D$ & $E$ & $A$ & $T$ & 636
\end{tabular} tcatcattagattcgattactgaagagactattcttggtgccatgagggatgtggtgaag 1980 $\begin{array}{lllllllllllllllllllllll}S & S & L & D & S & I & T & E & E & T & I & L & G & A & M & R & D & V & V & K & 656\end{array}$ cacagaacttctatttcatcgcacatagattgtcaacagtggttgatgcagatgaaatc 2040 $\begin{array}{lllllllllllllllllllll}H & R & T & S & I & F & I & A & H & R & L & S & T & V & V & D & A & D & E & I & 676\end{array}$ attgtcctgagccagggaaaagtagctgaacgtggtacccactatggtctgcttgctaac 2100

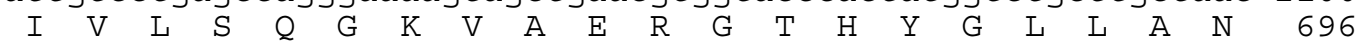
tctagcagtatctattcagagatgtggcatacacagagcacccgcatacagaaccatgat 2160 $\begin{array}{llllllllllllllllllllll}S & S & S & I & Y & S & E & M & W & H & T & Q & S & T & R & I & Q & N & H & D & 716\end{array}$ aaccttggatgggatgcaaagaaagagagtctctctaaagaggaggagagaaagaagctc 2220 $\begin{array}{lllllllllllllllllllllllllll}N & L & G & W & D & A & K & K & E & S & L & S & K & E & E & E & R & K & K & L & 736\end{array}$ caagaagagattgtcaacagcgtgaaaggctgtggaaattgctcctgctaaggaacacag 2280

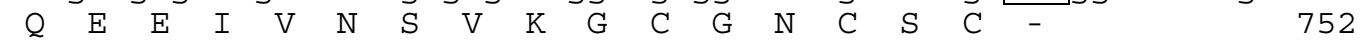
acatttctcgtcttcttttgttgtcttgttggtttgaatatgcatttgcactga 2340

Figure 6. Experimentally confirmed rAbcb7 cDNA nucleotide sequence and its derived amino acid sequence. Lower case letters comprise the sequence of the coding cDNA strand, whereas the capital letters beneath indicate the amino acid sequence. The start (atg) and stop (taa) codons as well as the characteristic motifs of the nucleotide binding cassette (Walker A, signature sequence and Walker B) are marked in frames.

Shortly before the experimental rAbcb7 sequence was clarified, a predicted rat Abcb7 encoding sequence appeared in GenBank (accession number: XM 217569). This sequence was received via gene prediction by computational analysis on an annotated genomic sequence. The alignment of the experimentally received $\mathrm{rAbcb} 7$ sequence (exp) with the predicted one (pred.) revealed two important differences in its 5'-end (fig. 7): the $60 \mathrm{bp}$ 
nucleotide fragment at the beginning of the sequence predicted in silico was not confirmed experimentally and the $78 \mathrm{bp}$ detected experimentally were not in the predicted $\mathrm{rAbcb} 7$ sequence. The predicted rAbcb7 sequence was in total 6 amino acids shorter than the experimental one. The blast analysis of the $\mathrm{rAbcb} 7 \mathrm{cDNA}$ sequence against the rat genome sequence positioned the $\mathrm{rAbcb} 7$ gene on the $\mathrm{X}$ chromosome $\mathrm{q}$ shoulder, which is in accordance with the position of the human hABCB7 gene.

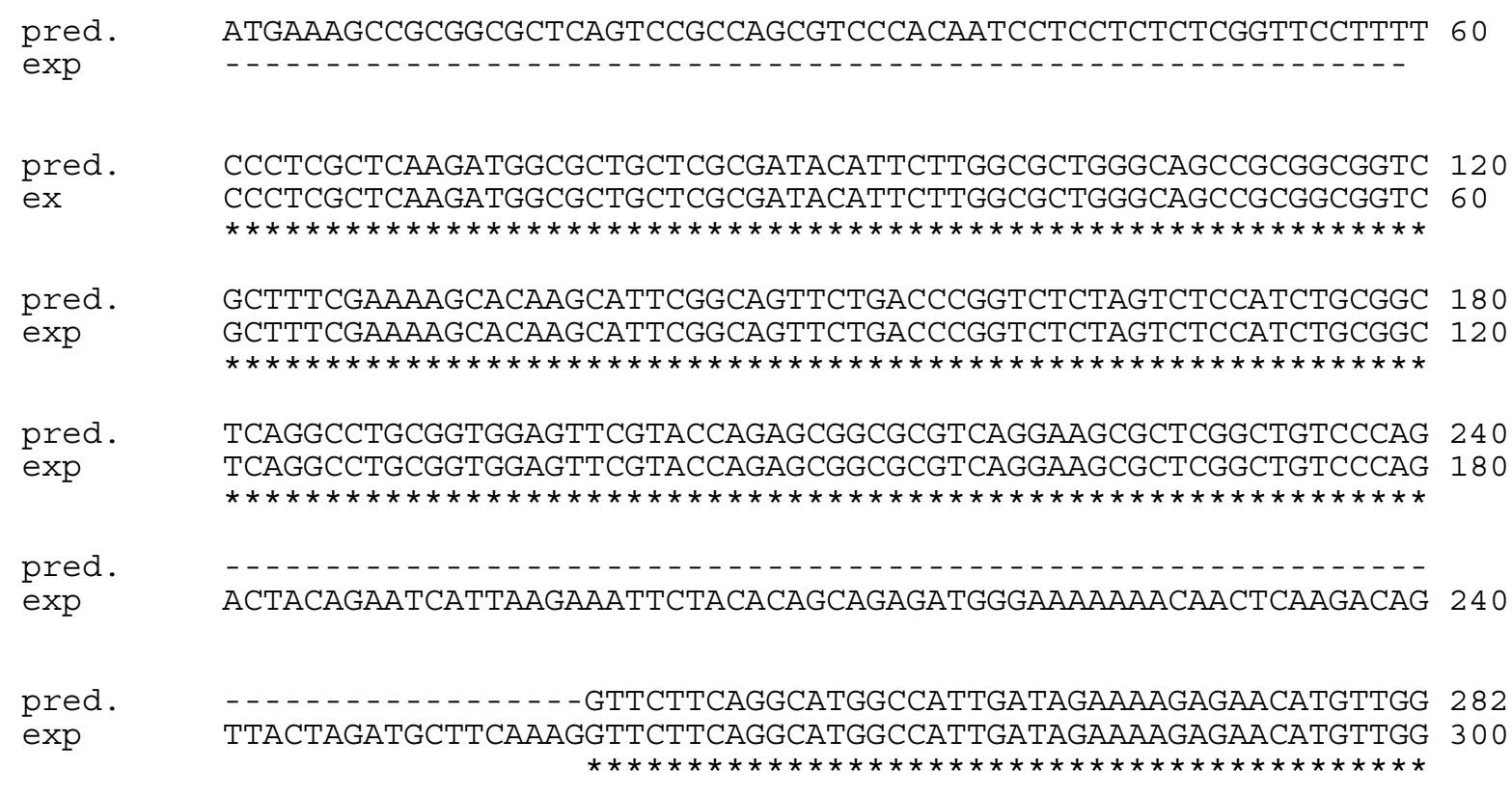

Fig. 6. Alignment of predicted $\mathbf{r A b c b} 7$ and experimentally received rAbcb7 sequences performed with the CLUSTAL W programme. A 78 bp gap was found in the predicted sequence, but the predicted sequence started $60 \mathrm{bp}$ earlier than the experimentally received one.

\subsubsection{Sequence variations discovered in rAbcb6 cDNA during re-cloning}

On the basis of the experimentally derived rAbcb6 sequence (Hirsch-Ernst et al., 1998, accession number NM 080582) primers B6F1, B6F2, B6F3, B6F4, B6F5 and B6R1 (chapter 2.1.7.3) were designed. Rat Abcb6 was re-cloned by means of RT-PCR (chapter 2.2.7.2) from rat hepatocyte RNA (chapter 2.2.2.4.1.1) using the B6F1 and B6R1 primers. The received rAbcb6 cDNA sequence was cloned into the pCR-XL-TOPO vector (chapter 2.2.6.1) to enable the verification of the nucleotide sequence by sequencing (chapter 2.2.9). Electro-competent bacteria were transformed with the construct by electroporation (chapter 
2.2.6.4), bacterial cultures grown and the construct was purified (chapter 2.2.2.1). The insert was sequenced (chapter 2.2.9) using primers B6F2, B6F3, B6F4 and B6F5. The sequencing revealed the presence of single nucleotide changes in the rAbcb6 cDNA sequence (table 10) as compared to the reference sequence (accession number NM 080582) and as compared to the rat genome sequence. Apart from such sequences, the clones were received that contained insert sequences in accordance with the reference sequence. The re-cloning experiment was repeated 9 times (table 11) using total RNA extracted from cultured and non-cultured rat hepatocytes as a template for cDNA synthesis. The goal was to find out whether these changes were restricted to one single rat or not. RT-PCR enzymes of two different suppliers, Super Script ${ }^{\mathrm{TM}}$ (Invitrogen) and Titan enzyme mix (Roche), were tested to exclude the possibility of an enzyme-dependent cause for the appearance of single nucleotide changes in the rAbcb6 cDNA sequence. The single nucleotide changes in the rAbcb6 cDNA sequence seemed to be consistent among the six rats tested and the majority of them resulted in amino acid changes in the protein sequence (table 11). Interestingly, none of the single nucleotide changes were found to affect the conserved motifs (Walker A, Signature motif and Walker B) of the rAbcb6 protein sequence. 
Table 10. Single nucleotide changes found in the rat Abcb6 cDNA sequence and their resulting changes in amino acid sequence. There were 14 single nucleotide changes found repeatedly for 9 times (table 11) in the rAbcb6 cDNA sequence that resulted in 11 single amino acid changes in protein sequence.

Protein sequence

\begin{tabular}{llll} 
Position & Change & Position & Change \\
\hline 55 & $\mathrm{a} \rightarrow \mathrm{g}$ & 19 & $\mathrm{~T} \rightarrow \mathrm{A}$ \\
800 & $\mathrm{t} \rightarrow \mathrm{c}$ & 267 & $\mathrm{~L} \rightarrow \mathrm{P}$ \\
1160 & $\mathrm{t} \rightarrow \mathrm{c}$ & 387 & $\mathrm{~L} \rightarrow \mathrm{P}$ \\
1239 & $\mathrm{t} \rightarrow \mathrm{c}$ & no change & \\
1322 & $\mathrm{a} \rightarrow \mathrm{g}$ & 441 & $\mathrm{D} \rightarrow \mathrm{G}$ \\
1359 & $\mathrm{a} \rightarrow \mathrm{g}$ & no change & \\
1373 & $\mathrm{t} \rightarrow \mathrm{c}$ & 458 & $\mathrm{~L} \rightarrow \mathrm{P}$ \\
1388 & $\mathrm{t} \rightarrow \mathrm{c}$ & 463 & $\mathrm{~V} \rightarrow \mathrm{A}$ \\
1721 & $\mathrm{t} \rightarrow \mathrm{c}$ & 574 & $\mathrm{~V} \rightarrow \mathrm{A}$ \\
2084 & $\mathrm{a} \rightarrow \mathrm{g}$ & 695 & $\mathrm{E} \rightarrow \mathrm{G}$ \\
2113 & $\mathrm{a} \rightarrow \mathrm{g}$ & 705 & $\mathrm{I} \rightarrow \mathrm{V}$ \\
2302 & $\mathrm{t} \rightarrow \mathrm{c}$ & 768 & $\mathrm{~S} \rightarrow \mathrm{P}$ \\
2306 & $\mathrm{t} \rightarrow \mathrm{a}$ & no change & \\
2450 & $\mathrm{t} \rightarrow \mathrm{c}$ & 817 & $\mathrm{~V} \rightarrow \mathrm{A}$ \\
& & &
\end{tabular}

Sequencing analysis of the re-cloning experiments showed that one of the six different rat RNA pools used also contained the rAbcb6 mRNA that had none of the single nucleotide changes listed in table 10. The rAbcb6 sequence used for construction of rAbcb6-EGFP and rAbcb6-DsRed2 expression vectors contained one base pair change at position $2378(\mathrm{t} \rightarrow \mathrm{c})$, resulting in a change at the amino acid level: $\mathrm{I} \rightarrow \mathrm{T}$. 
Table 11. Brief overview of rat rAbcb6 re-cloning experiments. Total RNA used for RTPCR application was extracted from the hepatocytes cultivated and freshly isolated out of 6 Wistar rats.

\begin{tabular}{|c|c|c|c|c|}
\hline No.* & $\begin{array}{l}\text { RNA extraction } \\
\text { date }\end{array}$ & $\begin{array}{l}\text { Hepatocytes } \\
\text { prior to the } \\
\text { RNA extraction }\end{array}$ & $\begin{array}{l}\text { RT-PCR } \\
\text { date }\end{array}$ & Changes $\otimes$ \\
\hline 1 & 21.4.2004 & cultivated & 13.5 .2004 & + \\
\hline \multirow[t]{4}{*}{2} & 02.4 .2004 & freshly isolated & 17.5.2004 & - \\
\hline & & & 19.7.2004 & + \\
\hline & & & 28.7.2004 & + \\
\hline & & & 27.8 .2004 & + \\
\hline \multirow[t]{3}{*}{3} & 23.6.2004 & cultivated & 24.6 .2004 & + \\
\hline & & & 29.6.2004 & + \\
\hline & & & 14.7.2004 & + \\
\hline \multirow[t]{2}{*}{4} & 06.8 .2004 & cultivated in & & \\
\hline & & serum-free media & 27.8 .2004 & + \\
\hline 5 & 26.8 .2004 & freshly isolated & 27.8 .2004 & + \\
\hline \multirow[t]{2}{*}{6} & 13.9.2004 & freshly isolated & 14.9.2004 & + \\
\hline & & cultivated & 14.9 .2004 & + \\
\hline
\end{tabular}

* - each number of RNA extraction corresponds to the male Wistar rat subjected to collagenase liver perfusion for hepatocyte isolation.

$\otimes$ - sequencing result analysis showed the presence $(+)$ or absence $(-)$ of single nucleotide changes listed in table 10 in the rAbcb6 cDNA sequence.

The rAbcb6 encoding sequence cloned into the rAbcb6-V5 expression vector corresponded to the reference coding sequence. 


\subsection{Distribution of rAbcb6 and $\mathrm{rAbcb} 7 \mathrm{mRNA}$ in primary rat hepatocytes and rat tissues}

Rat hepatocytes were isolated from rat liver (chapter 2.1.5.3) and seeded onto $58 \mathrm{~cm}^{2}$ plastic culture plates. To investigate possible mRNA expression changes during the cultivation time, primary rat hepatocytes were cultured for 1,2, 3 or 4 days (chapter 2.2.13.2), and total RNA was extracted from shock frozen cells (chapter 2.2.2.4.1.1). To examine whether hepatocyte cultivation might have influenced rAbcb6 or rAbcb7 mRNA expression levels, total RNA was also extracted from non-cultivated, freshly isolated primary rat hepatocytes. Tissues from rat organs (brain, heart, lung, testis, kidney, skeletal muscle and spleen) were used for total RNA extraction as described in chapter 2.2.2.4.1.2. Rat hepatocyte and tissue RNAs were subjected to denaturating RNA gel electrophoresis (chapter 2.2.10.2), followed by RNA transfer onto nylon membranes (chapter 2.2.11). Radioactive hybridization (chapter 2.2.12) of Northern blots with a ${ }^{32} \mathrm{P}$-labelled rAbcb6-specific oligonucleotide probe (chapter 2.1.7.3, table 4) yielded a band indicating the presence of a $3.4 \mathrm{~kb}$ transcript in rat hepatocytes and in the examined rat tissues (fig. 8). That confirmed the results published by Hirsch-Ernst et al., 1998. The rehybridization of the same Northern blots with a rAbcb7specific ${ }^{32} \mathrm{P}$-labelled probe (chapter 2.1.7.3, table 4) revealed the existence of $6.9 \mathrm{~kb}$ and 3.0 $\mathrm{kb}$ long mRNA transcripts in freshly isolated rat hepatocytes and tissues (fig. 8). Under hepatocyte culture conditions the level of both rAbcb7 mRNA transcripts decreased: only the $3.0 \mathrm{~kb}$ long rAbcb7 mRNA transcript was detectable in Northern blot analysis (fig. 8). The rAbcb6 $3.4 \mathrm{~kb}$ transcript was expressed throughout the entire cultivation time to the same extent as in freshly isolated rat hepatocytes. Rat Abcb6 and Abcb7 transcripts were ubiquitously expressed in all rat organs analyzed, but to a different extent: rAbcb7 mRNA was most abundant in heart, whereas rAbcb6 mRNA showed the strongest expression in testis. 


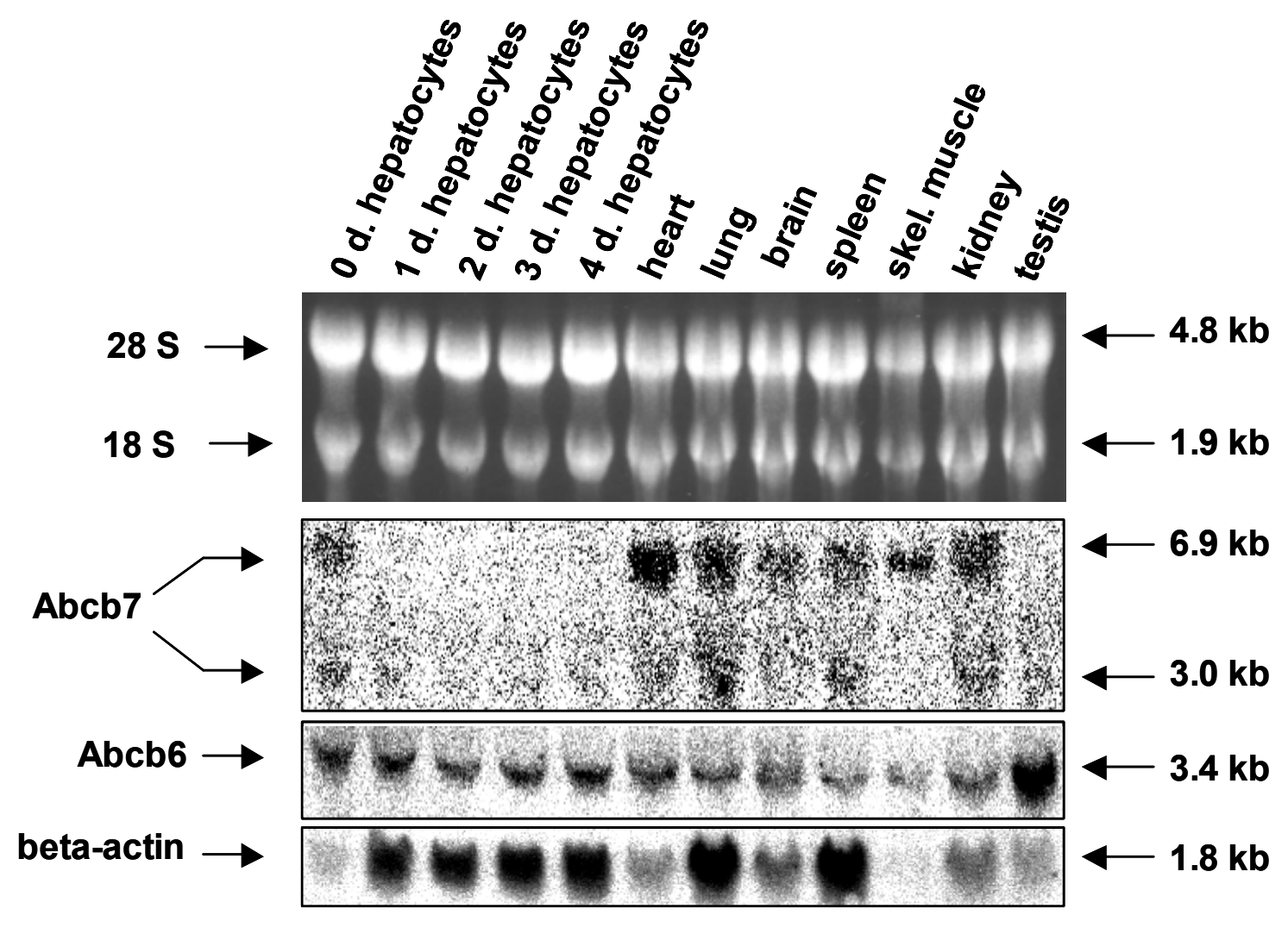

Figure 8. Expression of rAbcb7 and rAbcb6 $\mathrm{mRNA}$ in rat organs, freshly isolated primary hepatocytes and cultured rat hepatocytes - Northern blot analysis. Ethidium bromide staining of the RNA gel shows loading of samples according to $28 \mathrm{~S}$ and $18 \mathrm{~S}$ rRNA distribution. The RNA blot was hybridized and rehybridized with gene-specific probes for rAbcb6 and rAbcb7 mRNA, respectively. As a control for RNA loading in lanes with samples of cultivated rat hepatocyte RNA, rehybridization with a beta-actin probe was performed. Although beta-actin is regarded as a house-keeping gene, beta-actin is differentially expressed in organs. The highest expression of rAbcb7 mRNA was found in heart, whereas rAbcb6 mRNA was most abundant in testis. The expression level of rAbcb7 mRNA decreased during the cultivation time of rat hepatocytes $(0-4$ days (d.)), whereas rAbcb6 expression remained constant throughout the cultivation period.

These results were confirmed by analyzing rAbcb6 and rAbcb7 mRNA expression in Northern blots prepared from the total RNA extracted from tissues and hepatocytes of three different rats. 


\subsection{Localization studies of rAbcb6 and rAbcb7}

To study subcellular localization of rAbcb6 and rAbcb7 in situ in cell cultures, LoVo, TM3 and HEK293 cells were transiently transfected (chapter 2.2.14) with the rAbcb6-EGFP, rAbcb6-DsRed2, rAbcb6-V5, rAbcb7-EGFP, rAbcb7-DsRed2 and rAbcb7-V5 fusion protein encoding vectors (chapter 2.2.8). Prior to transfection, the cell lines were characterized for endogenous $\mathrm{rAbcb6} / \mathrm{rAbcb} 7$ expression.

\subsubsection{Characterization of cell lines used for transfection experiments}

To define whether LoVo, TM3 and HEK293 cells expressed endogenous human ABCB6/ABCB7 (LoVo, HEK293) or murine mAbcb6/mAbcb7 (TM3) mRNA, RT-PCR was performed (chapter 2.2.7.2). Total RNA extracted from the LoVo, TM3 and HEK293 cell lines (chapter 2.2.2.4.1.1) were used as a template for reverse transcription-PCR (RTPCR). The alignment of mAbcb7 and mAbcb6 with the rat rAbcb7 and rAbcb6 showed that primers designed for the rat $\mathrm{rAbcb} 7 / \mathrm{rAbcb} 6, \mathrm{~B} 7 \mathrm{~F} 6$ with B7R3 and B6F1 with B6R2 (chapter 2.1.7.3), could be used for detection of $\mathrm{mAbcb} 7 / \mathrm{mAbcb} 6 \mathrm{mRNA}$ expression. The expected length of mAbcb7 and mAbcb6 cDNA was $552 \mathrm{bp}$ and $1154 \mathrm{bp}$, respectively. The RT-PCR resulted in a $\sim 550 \mathrm{bp}$ long mAbcb7 cDNA fragment and a 1150 bp long mAbcb6 fragment, indicating the presence of endogenous mAbcb7 and mAbcb6 in mouse TM3 cells. The RT-PCR with total RNA extracted from rat hepatocytes was performed as a positive control (fig. 9A). 
For detection of human ABCB6 mRNA expression, sense and anti-sense primers (table 5, chapter 2.1.7.3) were designed and the cDNA fragment was expected to be $2637 \mathrm{bp}$ long. Alignment of human ABCB7 with the rat $\mathrm{rAbcb} 7$ showed that B7F6 designed for rAbcb7 could be used for human ABCB7 cDNA amplification, yielding a 2263 bp cDNA fragment together with the anti-sense primer purchased for human ABCB7, both in LoVo and HEK293 cells.

The RT-PCR with primers for human ABCB6 detection resulted in an approximately $2.6 \mathrm{~kb}$ long cDNA fragment in HEK293 cells (fig. 9B). RT-PCR with LoVo mRNA yielded only the $2.3 \mathrm{~kb}$ cDNA band that resulted from primers used for human ABCB7 detection, but not the ABCB6 band. Thus, RT-PCR results indicated that HEK293 cells were positive for human ABCB6 and ABCB7 mRNA expression, whereas LoVo cells endogenously expressed only ABCB7 mRNA, but appeared to be devoid of endogenous ABCB6 mRNA expression. 
A

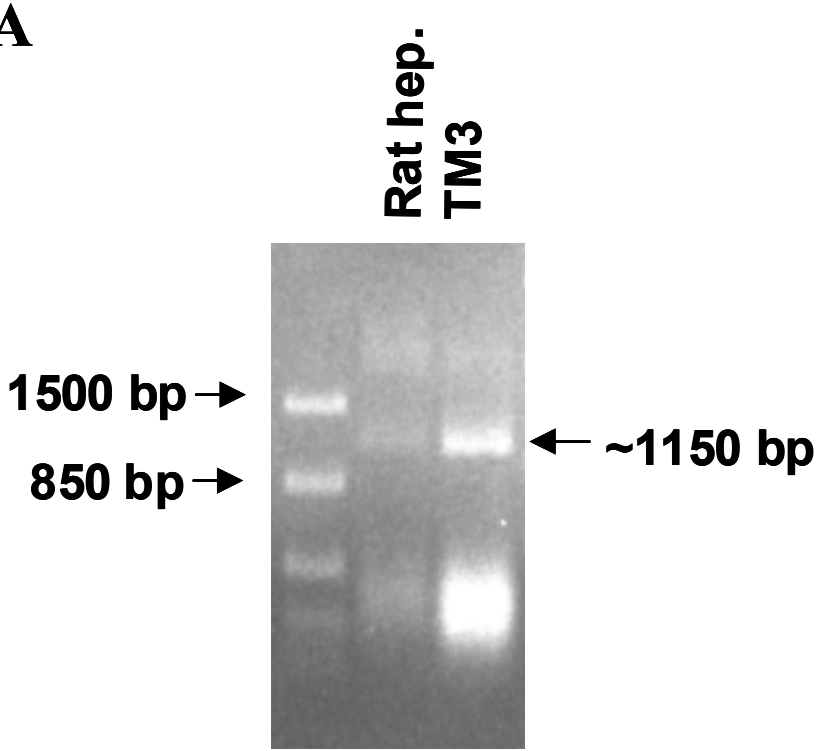

$\mathrm{rAbcb6/mAbcb6}$

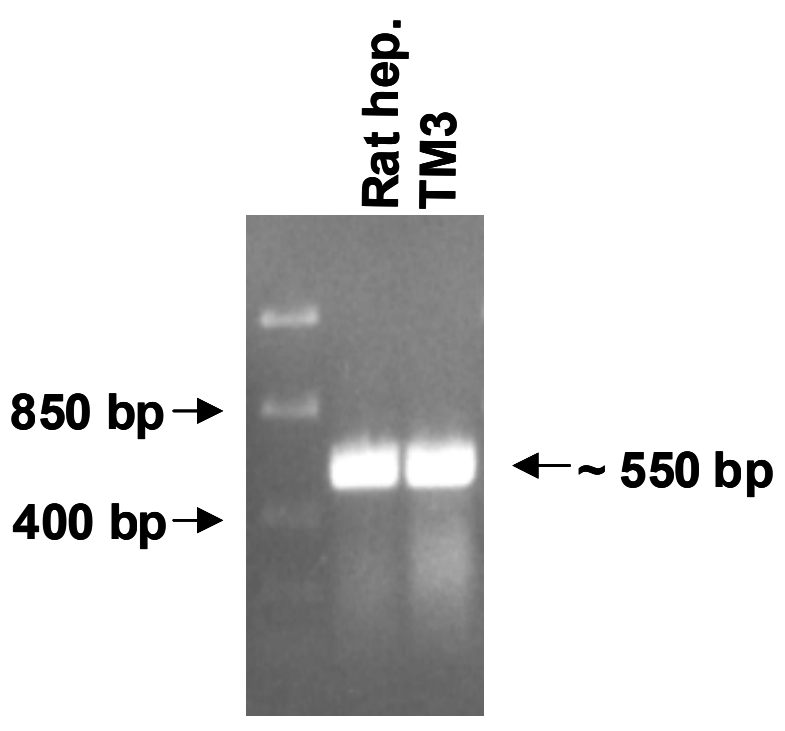

$\mathrm{rAbcb7/mAbcb7}$

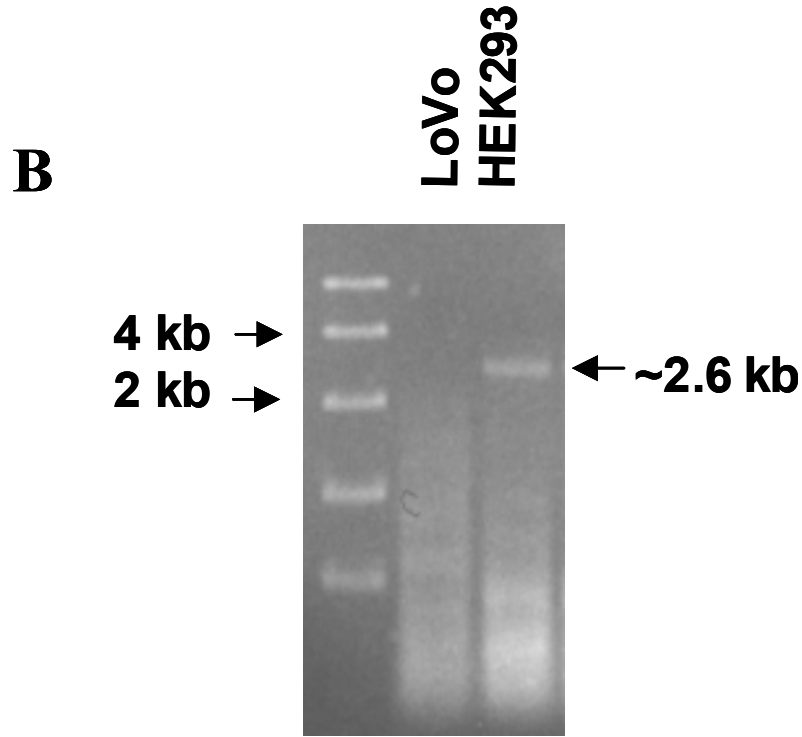

ABCB6

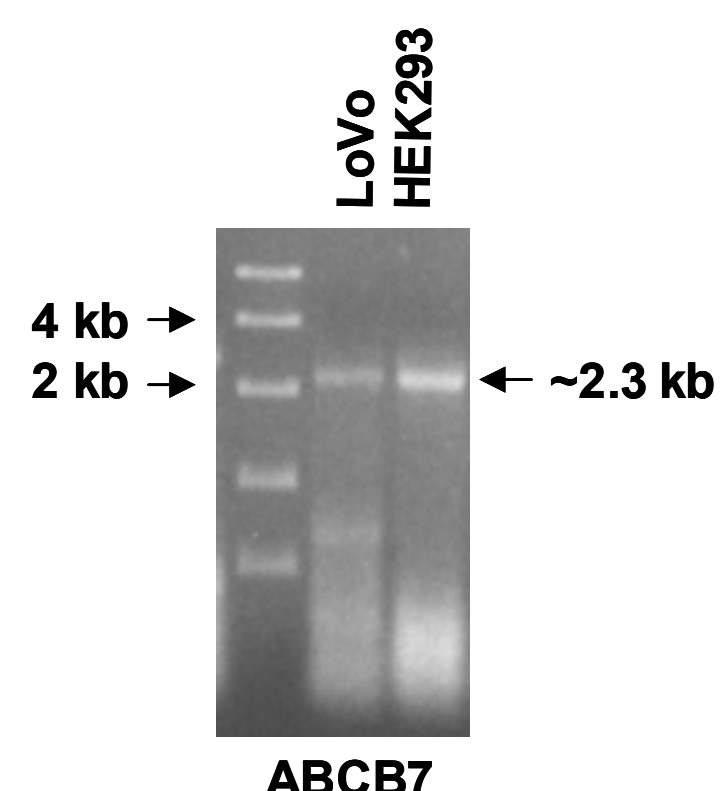

Figure 9. Detection of endogenous murine mAbcb6/mAbcb7 and human ABCB6/ABCB7 mRNA expression via RT-PCR application in TM3 (A) LoVo and HEK293 (B) cells, respectively. TM3 and HEK293 transcribed both mRNAs endogenously, whereas LoVo cells synthesized only ABCB7 mRNA. RT-PCR with rat hepatocyte RNA (isolated from hepatocytes cultured for 4 days) was performed as a positive control (A). 


\subsubsection{Expression of tagged rAbcb7 and rAbcb6 proteins in situ in living cells}

LoVo and HEK293 cells were transiently transfected with expression vectors yielding rAbcb6-EGFP, rAbcb6-DsRed2, rAbcb6-V5, rAbcb7-EGFP, rAbcb7-DsRed2 or rAbcb7-V5 fusion proteins using the Fugene 6 transfection reagent (chapter 2.2.14.2). TM3 cells were transfected via electroporation (chapter 2.2.14.1). Time-dependent rAbcb6-EGFP and rAbcb7-EGFP fusion protein expression in transiently transfected LoVo, HEK293 and TM3 cells was explored (fig. 10 and 11) to define the optimal time required for fusion protein expression in the co-transfection experiments. Rat Abcb6-EGFP was expressed within the observed period of time (1-3 days). Twenty four hours after transfection rAbcb7-EGFP fusion protein was not yet expressed in LoVo cells. Generally, the highest and most distinct expression of rAbcb6-EGFP and rAbcb7-EGFP fusion proteins was observed $48 \mathrm{~h}$ after transfection. The punctate pattern exhibited by the rAbcb6-EGFP fusion protein (fig. 10) and the vermiform pattern yielded by the rAbcb7-EGFP fusion protein (fig. 11) were not cell line-dependent. 


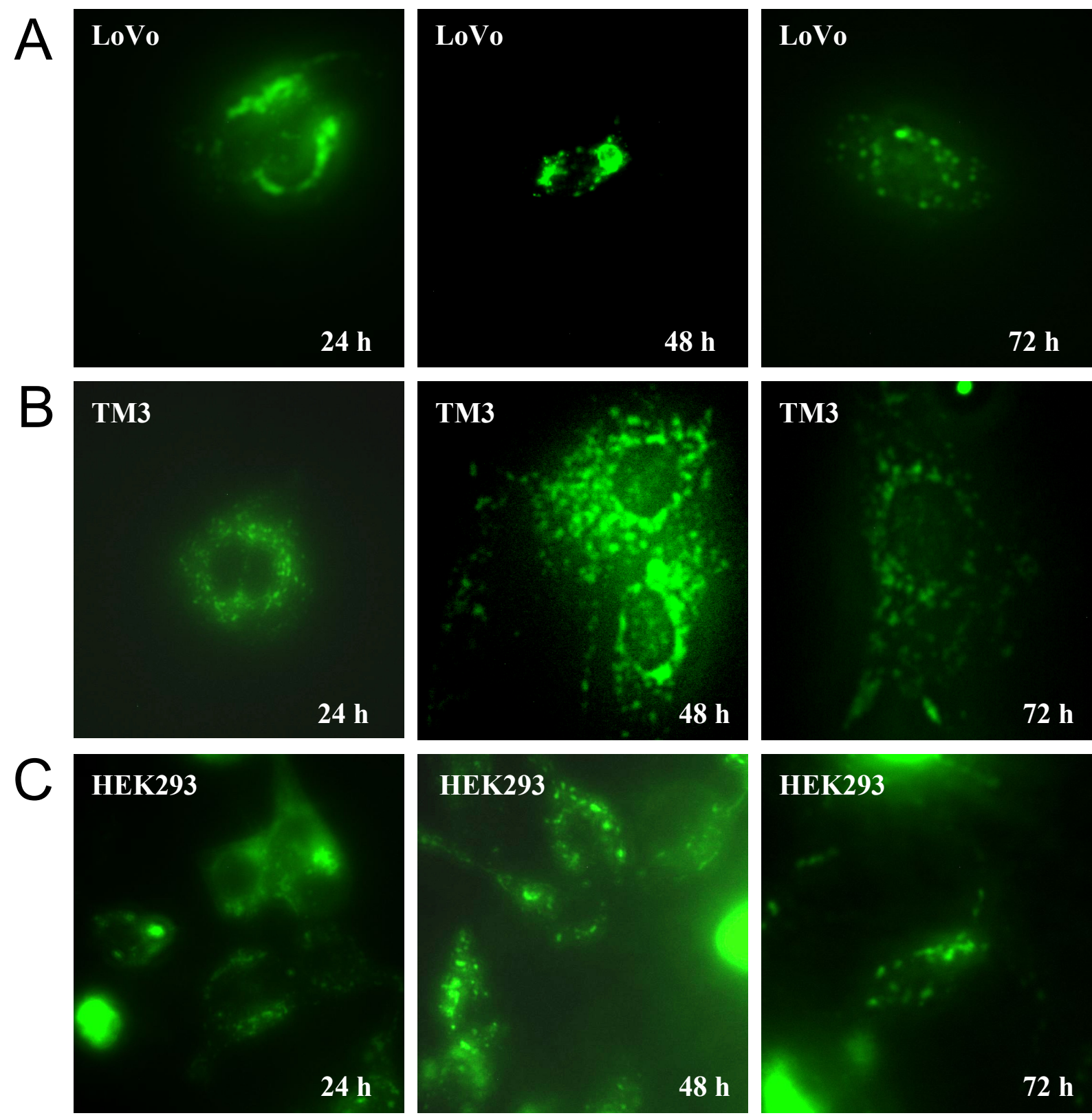

Figure 10. Time-dependent rAbcb6-EGFP fusion protein expression in transiently transfected LoVo (A), TM3 (B) and HEK293 (C) cells. rAbcb6-EGFP dependent fluorescence was observed already $24 \mathrm{~h}$ and at least up to $72 \mathrm{~h}$ after transfection. The magnification of cells was 630 -fold. 


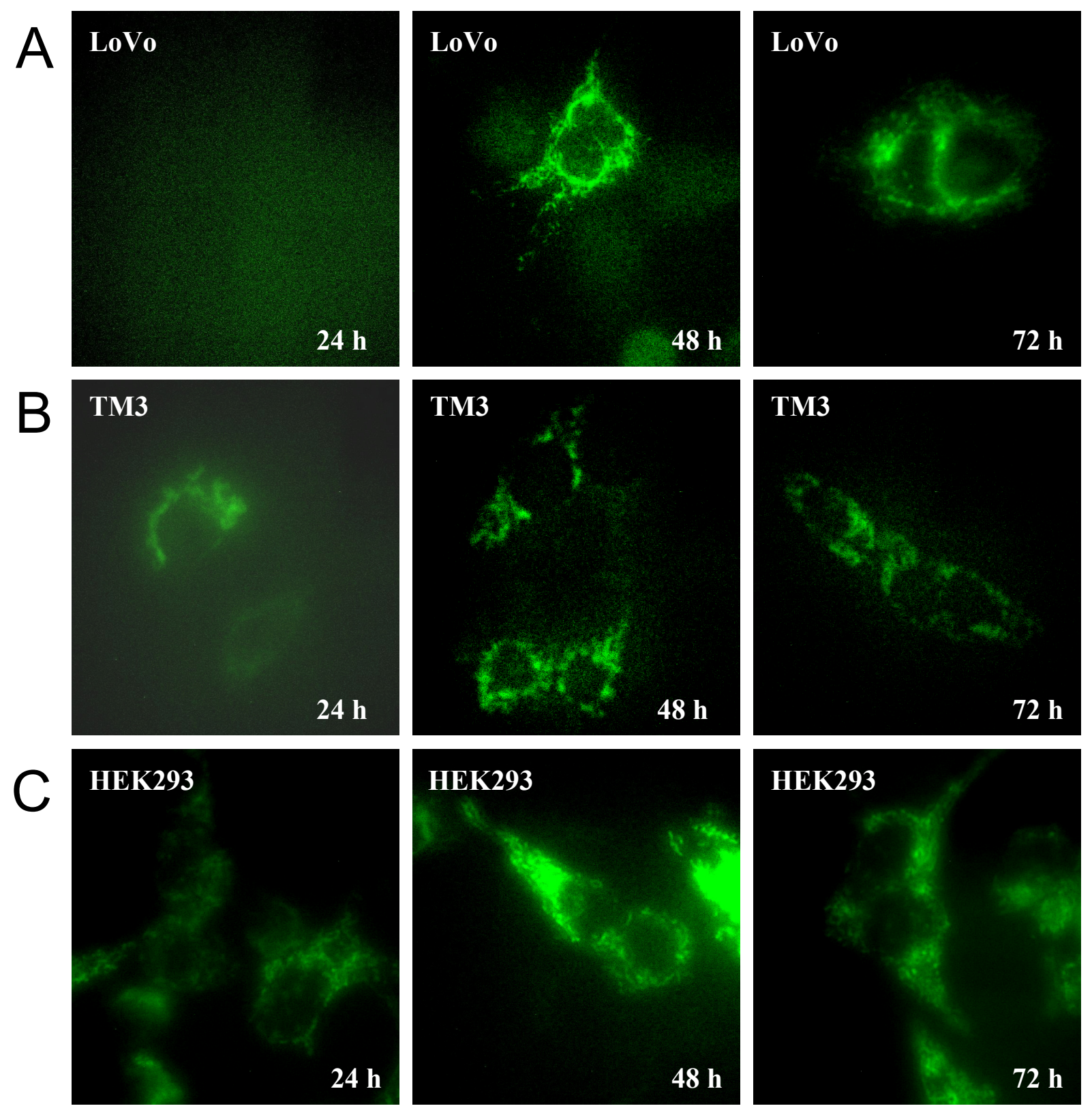

Figure 11. Time-dependent rAbcb7-EGFP fusion protein expression in transiently transfected LoVo (A), TM3 (B) and HEK293 (C) cells. LoVo cells did not express rAbcb7-EGFP fusion protein $24 \mathrm{~h}$ after transfection, whereas TM3 and HEK293 cells did. The rAbcb7-EGFP fusion protein was most distinctly expressed $48 \mathrm{~h}$ after transfection. The magnification of cells was 630 -fold. 
Long-term treatment of LoVo cells transfected with expression vectors bearing rAbcb7DsRed2 or rAbcb6-EGFP cDNA with G418 resulted in the development of stably transfected LoVo cell lines, due to vector-dependent expression of an amino glycoside resistance gene. Documentation of living cells treated with G418 for several months (fig. 12) indicated that the intracellular pattern of distribution was comparable to the pattern in transiently transfected cells. However, in spite of constant treatment with G418, the expression rate decreased with time. Therefore, transient transfection was chosen for the co-localization studies.
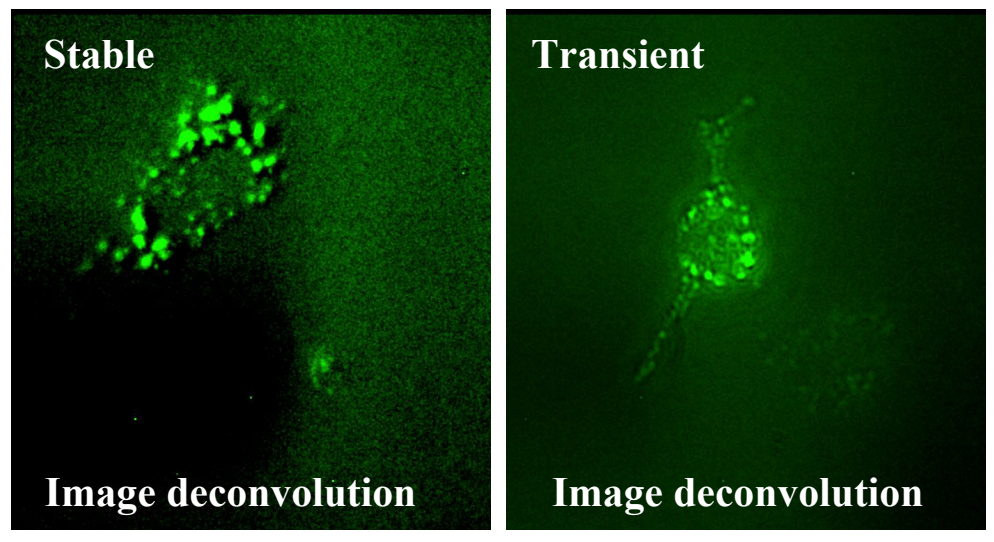

Figure 12. rAbcb6-EGFP fusion protein expression in stably and transiently transfected LoVo cells. Image processing via deconvolution emphasized the punctated pattern of distribution. The distribution pattern in stably-transfected cells was documented 2 months after transfection. The magnification of cells was 630 -fold. 
Observation of LoVo cells transiently co-transfected with rAbcb6-EGFP and rAbcb6-V5 or with rAbcb6-DsRed2 and rAbcb6-EGFP demonstrated that the expression patterns exhibited by the rAbcb6 fusion proteins were not tag dependent and that different tags did not influence the protein localization (fig. 13A and 13B). Similar results were obtained in cotransfection experiments involving the co-expression of rAbcb7-EGFP and rAbcb7-DsRed2 (fig. 13C). Experiments involving expression of rAbcb7-V5 demonstrated a distribution pattern of V5 immunoreactivity that was in line with rAbcb7-EGFP and rAbcb7-DsRed2 distribution (data not shown). A 100\% co-localization of rAbcb6 with itself and rAbcb7 with itself was observed (fig. 13). The fluorescence exhibited by rAbcb6-EGFP, rAbcb6-DsRed2, Abcb7-EGFP and rAbcb7-DsRed2 fusion proteins was directly observed via fluorescence microscopy (chapter 2.2.15.2) in living cells, whereas the V5-tagged fusion proteins were detected after performing immunofluorescence with FITC-conjugated anti V5 antibody (chapter 2.2.15.1) in cells fixed with methanol. The tags were detectable after fixation with methanol. 


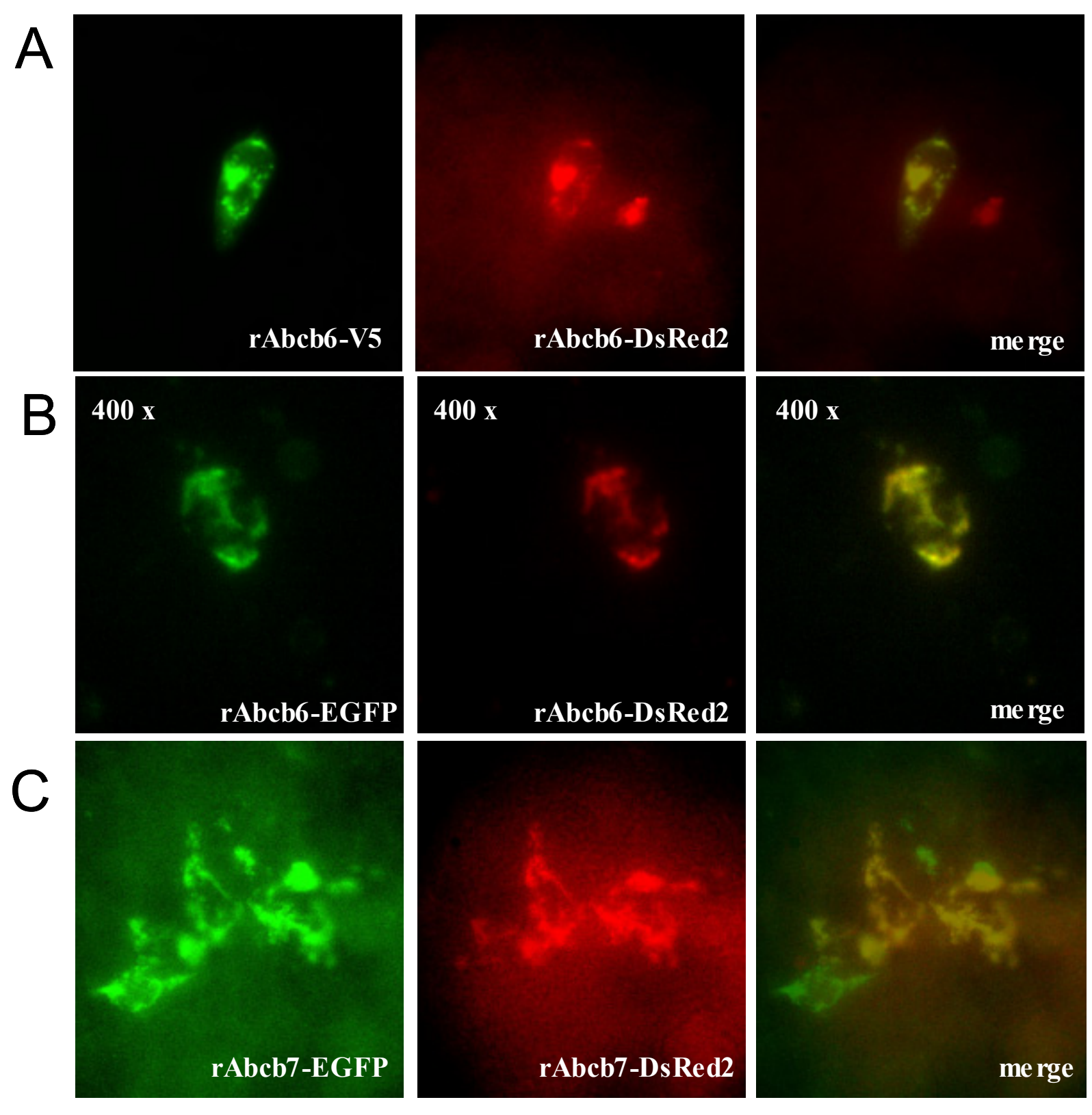

Figure 13. Co-expression of rAbcb6-V5 with rAbcb6-DsRed2 (A), rAbcb6-EGFP with rAbcb6-DsRed2 (B) and rAbcb7-EGFP with rAbcb7-DsRed2 (C) in LoVo cells. In cells expressing both fusion proteins (rAbcb6-V5/rAbcb6-DsRed2) and (rAbcb6-EGFP/rAbcb6DsRed2) or (rAbcb7-EGFP/rAbcb7-DsRed2), the strict co-localization of rAbcb7 and rAbcb6 with themselves was observed $48 \mathrm{~h}$ after transient transfection of fixed LoVo cells, indicating that the expression and localization of rAbcb6- or rAbcb7- was not tag-dependent. The magnification of cells was 630 -fold $(\mathrm{A}, \mathrm{C})$ or 400 -fold. 


\subsubsection{Co-expression of EGFP- and DsRed2-tagged rAbcb6 and rAbcb7 in mammalian cell lines}

Human LoVo cells were first chosen for the co-expression experiments because the cells produced no endogenous ABCB6 (chapter 3.3.1) and were able to co-express both EGFPand DsRed2-tagged fusion proteins (chapter 2.2.15.2).

The rAbcb6-EGFP and rAbcb7-DsRed2 fusion proteins co-expressed in LoVo cells showed almost no co-localization (fig. 14). The result of the experiment depicted in figure 13

confirmed the reliability of the co-transfection results depicted in figure 14, suggesting different intracellular localization of rAbcb6 and rAbcb7 proteins. 

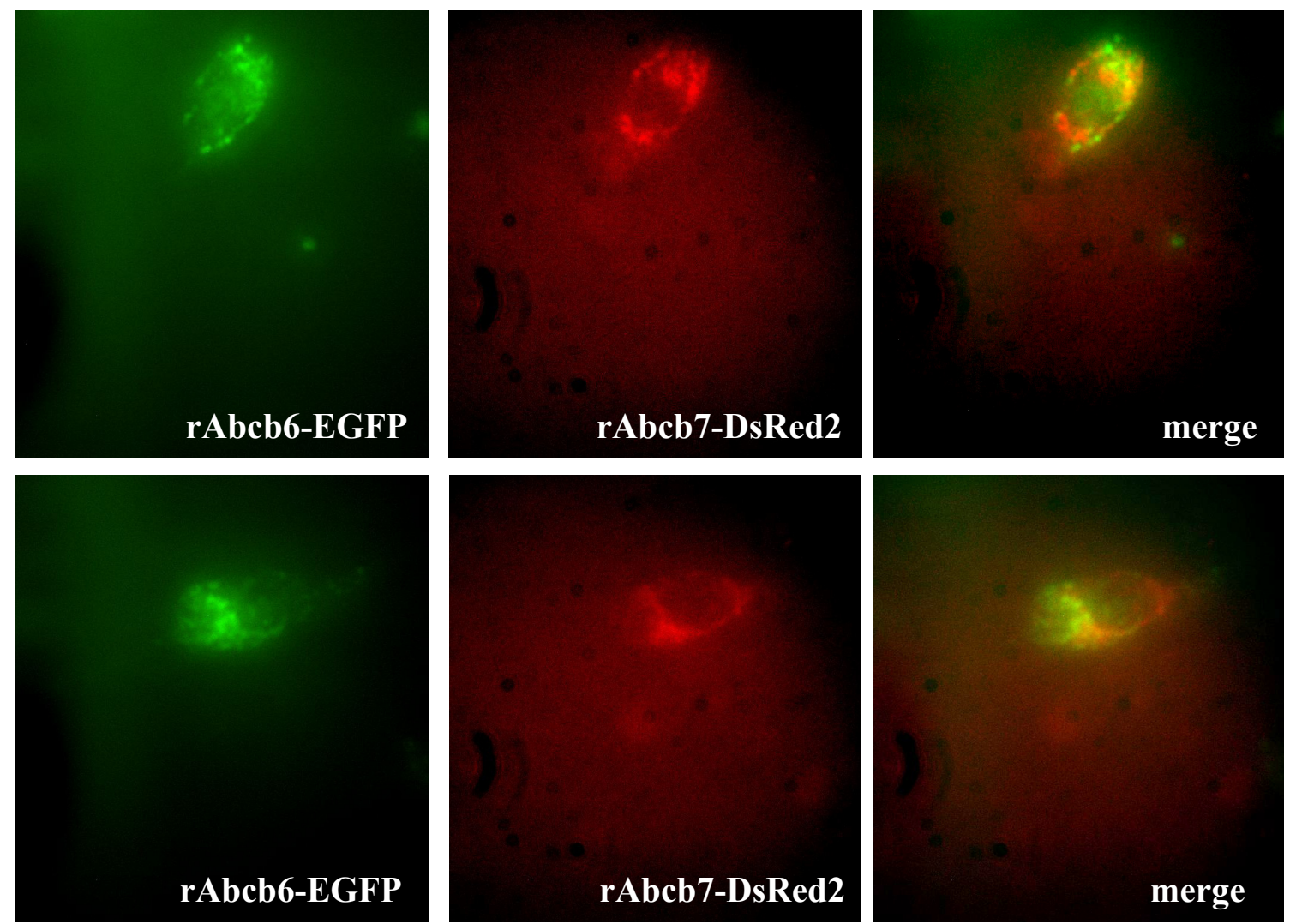

Figure 14. Co-transfection of rAbcb7-DsRed2 and rAbcb6-EGFP. Red fluorescence of the rAbcb7-DsRed2 fusion protein and green fluorescence of the rAbcb6-EGFP showed very little overlap in transiently transfected LoVo cells $48 \mathrm{~h}$ after transfection. The magnification of cells was 630 -fold. 


\subsubsection{Co-expression of rAbcb6 and rAbcb7 with marker plasmids}

Intracellular localization studies were performed by transiently co-transfecting LoVo cells with vectors containing rAbcb6-EGFP or rAbcb7-EGFP cDNA and organelle marker expression plasmids. The co-expression of rAbcb6-EGFP with the mitochondrial marker (a protein consisting of the mitochondrial targeting sequence of cytochrom $\mathrm{C}$ oxidase subunit VIII and DsRed) in living, unfixed LoVo cells did not indicate that rAbcb6 was substantially co-localized with mitochondria (fig. 15). This result was confirmed by observing the fluorescence of rAbcb6-EGFP and mito-DsRed fusion proteins in fixed LoVo cells with a different microscope system and image processing software (ApoTome microscope system, fig. 16). Non-mitochondrial rAbcb6 localization was supported by co-expression of rAbcb6EGFP and mito-DsRed fusion proteins in TM3 cells (fig. 17) that had previously been shown to also express endogenous mAbcb6 (fig. 9). 


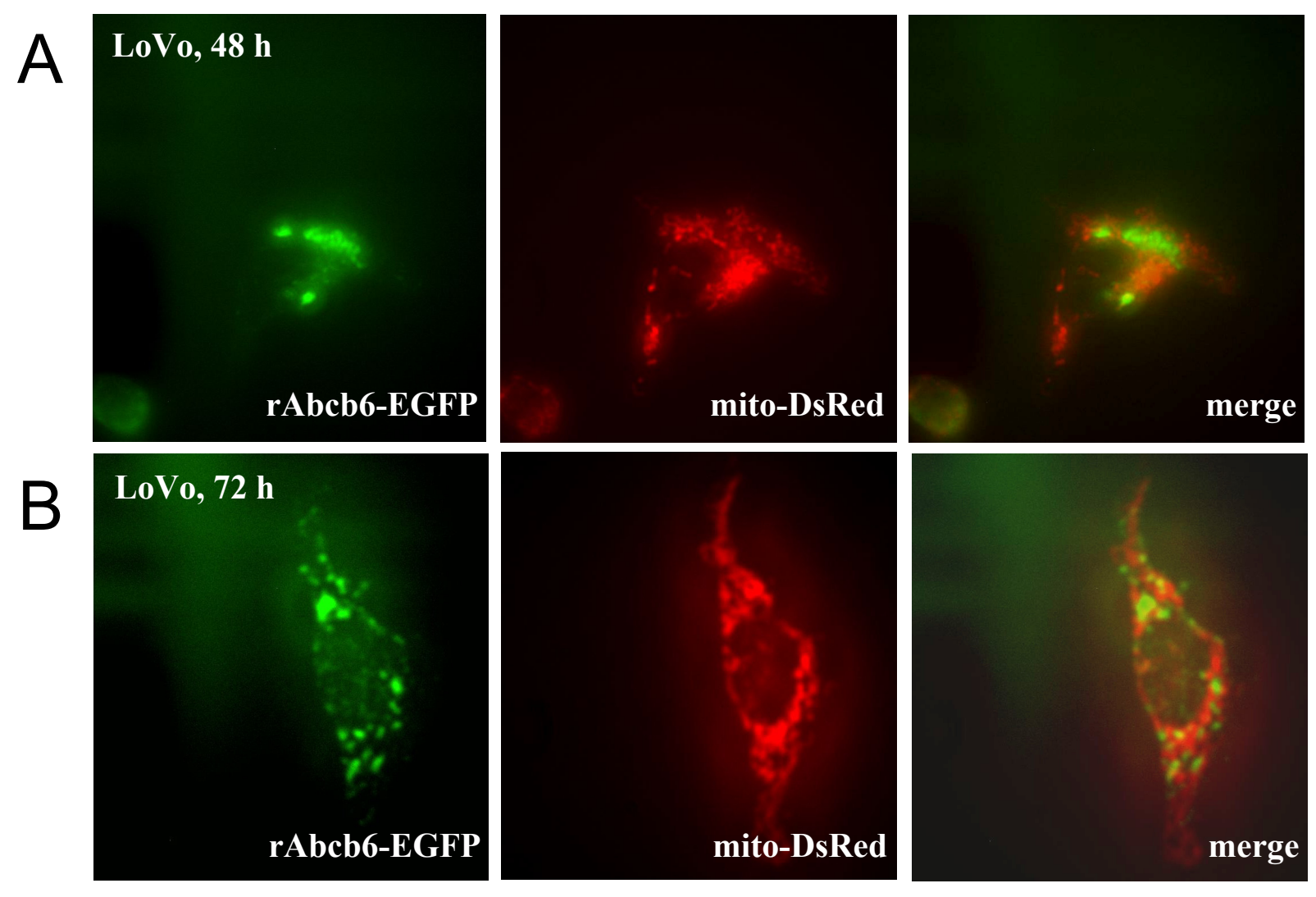

Figure 15. rAbcb6-EGFP fusion protein co-expression with mitochondrial marker protein in LoVo cells. The photos of living cells were made $48 \mathrm{~h}$ (A) and $72 \mathrm{~h}$ (B) after transient transfection. Almost no co-localization of rAbcb6-EGFP and mitochondrial marker (mito-DsRed) fusion proteins was observed. The magnification of cells was 630-fold. 


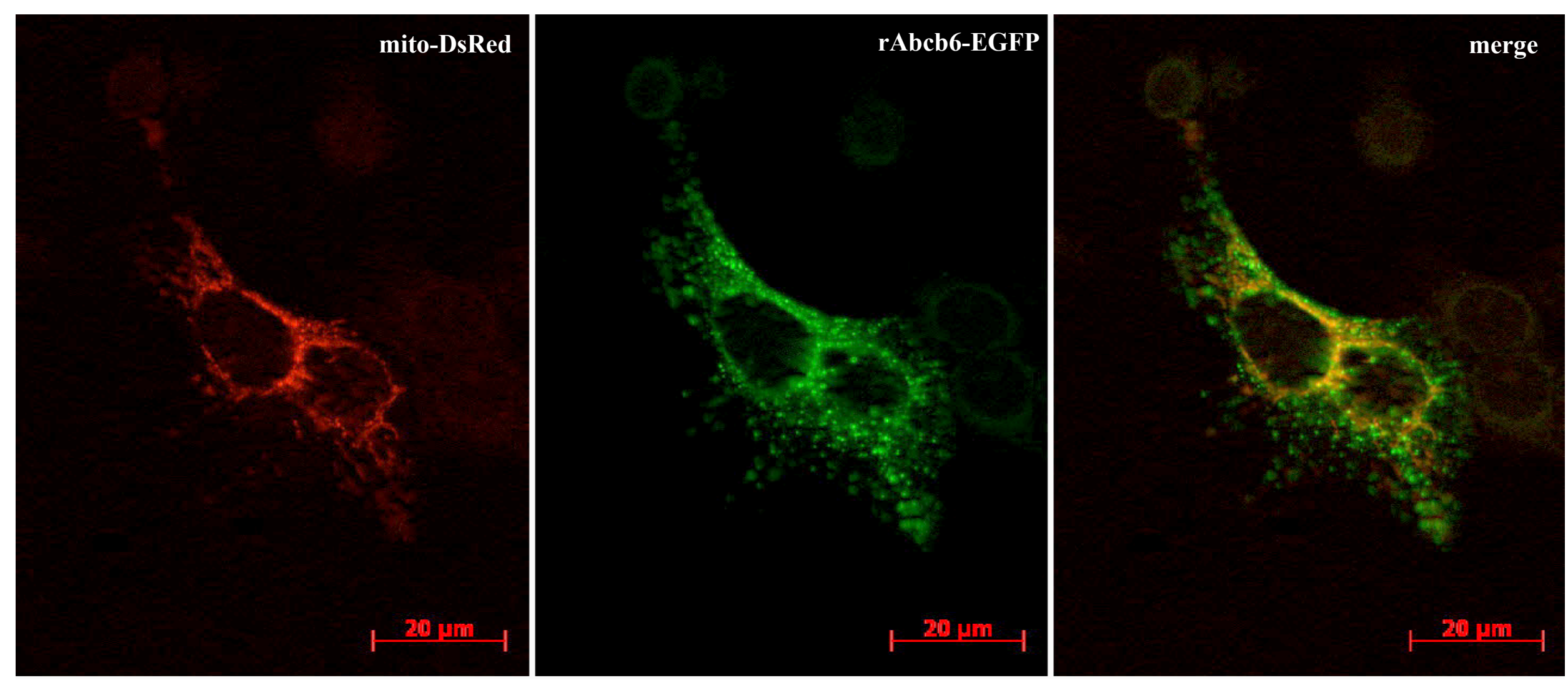

Figure 16. rAbcb6-EGFP co-expression with mitochondrial marker (mito-DsRed) in fixed LoVo cells, observed through ApoTome microscope. Transiently transfected LoVo cells were fixed $48 \mathrm{~h}$ after transfection and observed at 630 -fold magnification. The mitochondrial marker exhibited a vermiform pattern of fluorescence, while green fluorescent rAbcb6-EGFP showed a punctated pattern of distribution. 

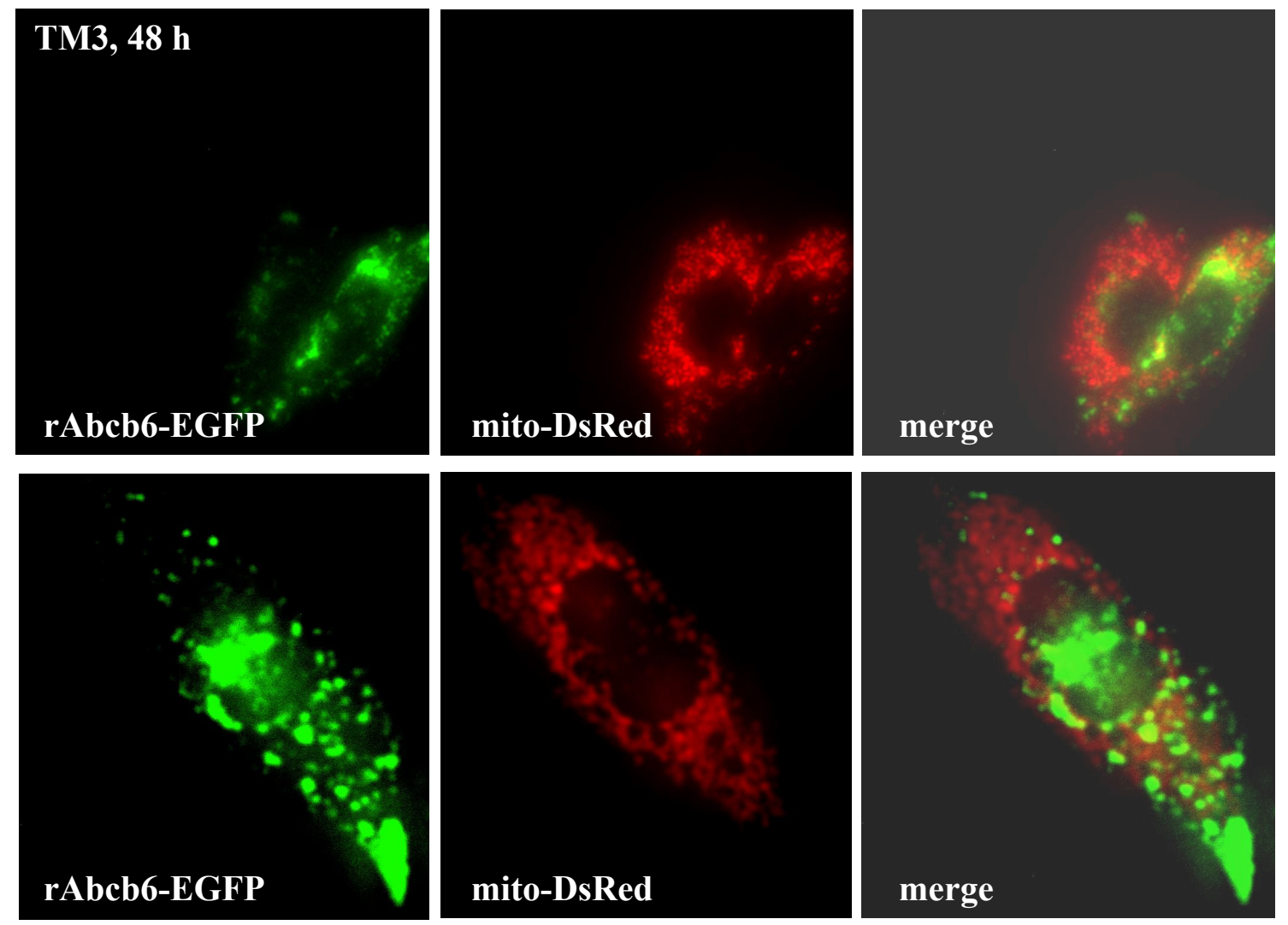

Figure 17. Co-expression of rAbcb6-EGFP and mito-DsRed fusion proteins in TM3 cells. Very little overlap in fluorescence pattern was observed $48 \mathrm{~h}$ after transient transfection in living TM3 cells. The magnification of cells was 630-fold. 
A vector expressing DsRed-tagged lysosomal/late endosomal marker Lamp1 (received from Dr. T. Kietzmann, University of Kaiserslautern) when transfected into TM3 or LoVo cells yielded a fusion protein with differing time-dependency. In LoVo cells Lamp1-DsRed fusion protein expression was optimal approximately $72 \mathrm{~h}$ after transfection, while the expression in TM3 cells was detectable already $24 \mathrm{~h}$ after transfection. Due to this fact, co-expression of Lamp1-DsRed and rAbcb6-EGFP fusion proteins in LoVo cells was achieved by transfecting the rAbcb6-EGFP cDNA bearing vector $24 \mathrm{~h}$ later than the Lamp1-DsRed cDNA carrying one (fig. 18). Substantial co-localization of rAbcb6-EGFP and Lamp1-DsRed fusion proteins was observed in living LoVo cells. The same percentage of rAbcb6-EGFP co-localization with Lamp1-DsRed was observed to a similar extent $24 \mathrm{~h}$ after TM3 cells had been transfected with expression vectors bearing the cDNA of fusion proteins (fig. 18). 


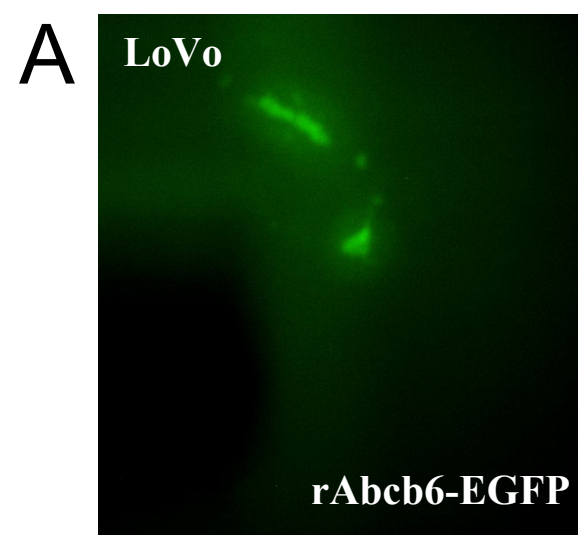

$\mathrm{B}$

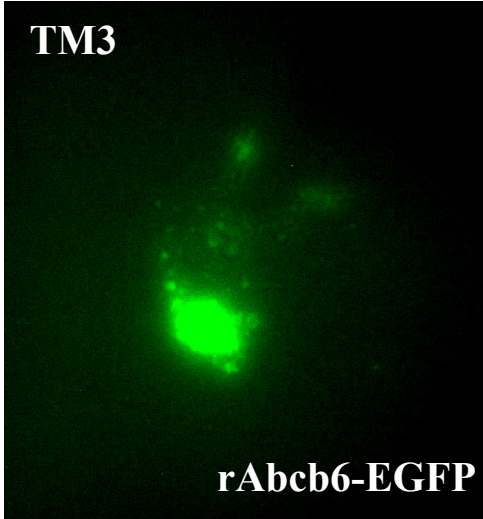

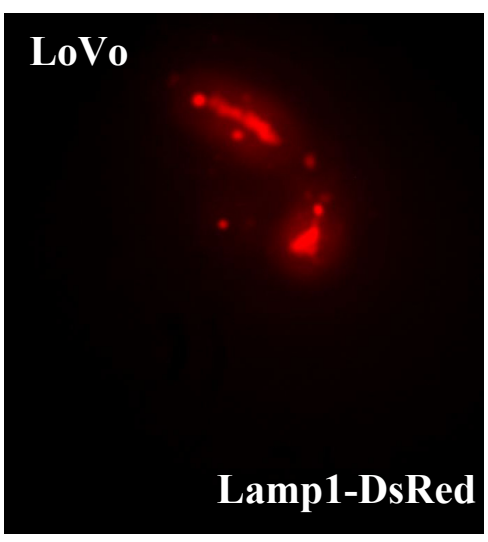

TM3

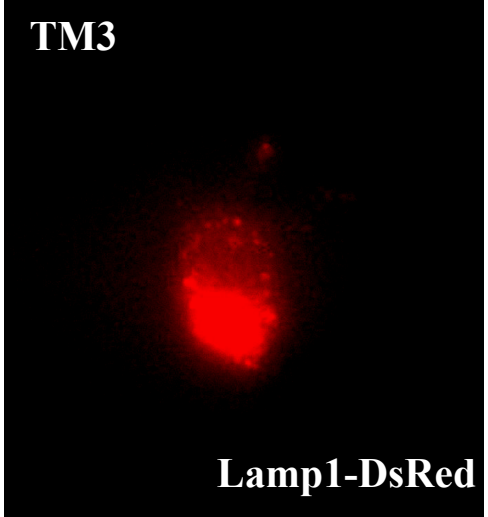

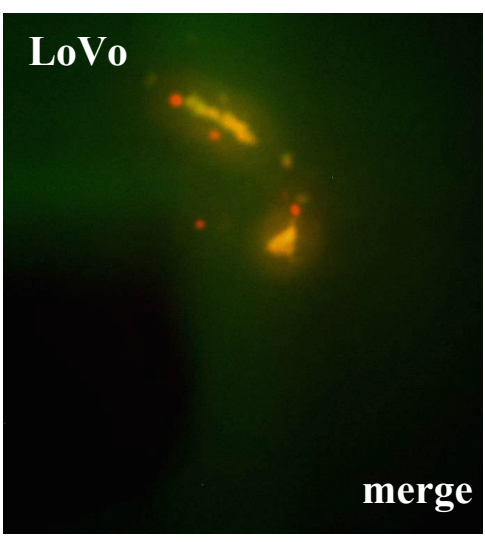

TM3

Figure 18. Co-expression of rAbcb6-EGFP and Lamp1-DsRed fusion proteins in living, unfixed LoVo (A) and TM3 (B) cells. The fluorescence in living TM3 cells was documented $24 \mathrm{~h}$ after transfection, whereas for documentation of LoVo cells, $72 \mathrm{~h}$ were required for optimal expression of Lamp1-DsRed. The magnification of cells was 630-fold. 
The co-expression of rAbcb7-EGFP and mito-DsRed (mitochondrial marker, BD Biosciences) in LoVo and HEK293 cells showed rAbcb7-EGFP co-localization with the mitochondrial marker (fig. 19). This was confirmed by observing the fluorescence of rAbcb7-EGFP and mito-DsRed fusion proteins in fixed LoVo cells with the ApoTome microscope system (Zeiss, Goettingen, Germany) and documenting with an AxioCam and processing with AxioVision software (fig. 19). 

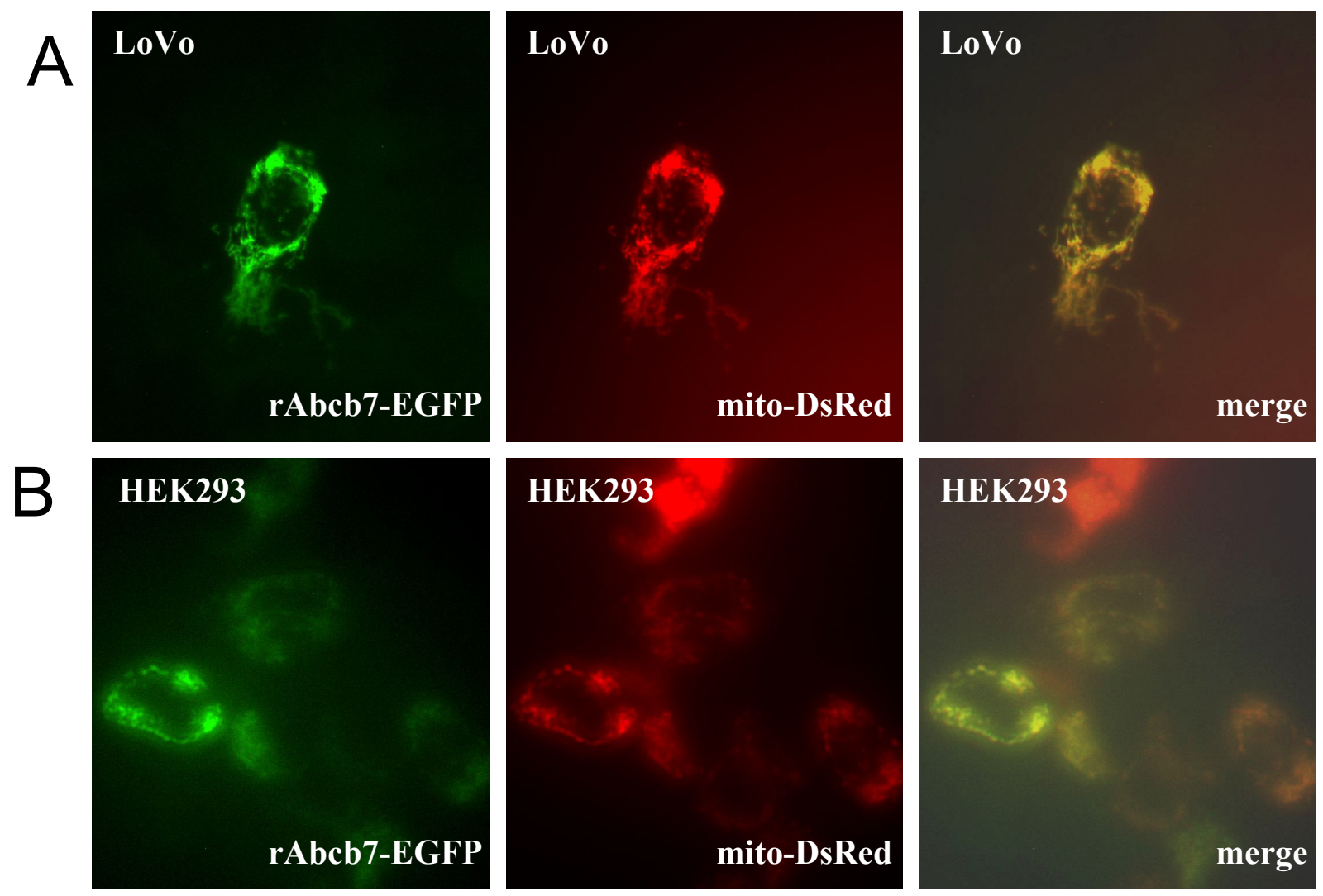

HEK293

\section{rAbcb7-EGFP+mito-DsRed via ApoTome microscope}

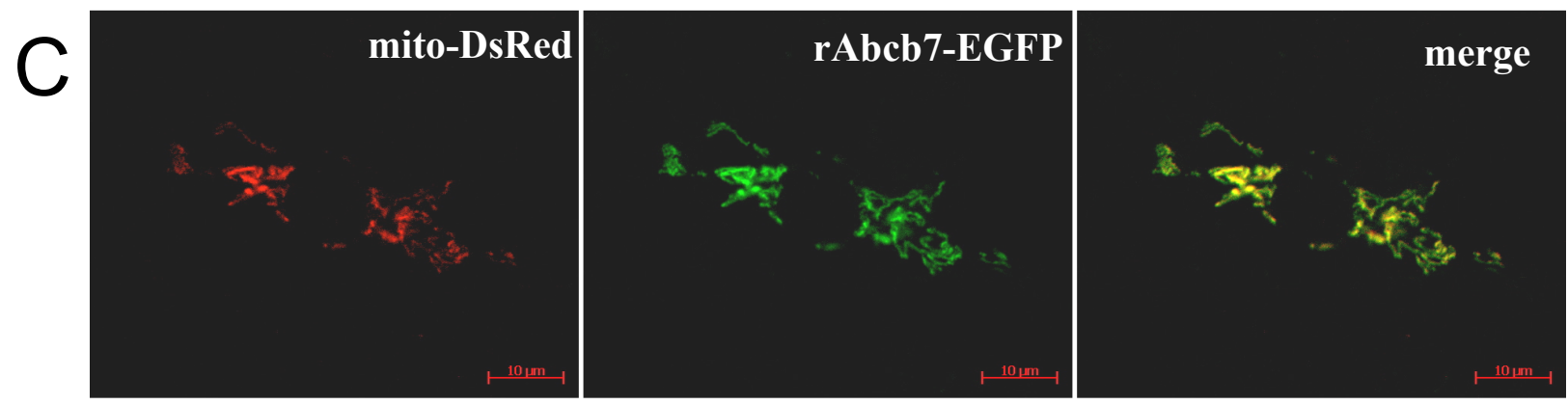

Figure 19. rAbcb7-EGFP and mitochondrial marker protein (mito-DsRed) coexpression in LoVo (A, C) and HEK293 (B) cells. 100\% co-localization was observed in fixed LoVo cells and in living HEK293 cells expressing both rAbcb7-EGFP and mito-DsRed fusion proteins $48 \mathrm{~h}$ after transfection. The last three LoVo cell photos were obtained via fluorescence microscopy with the ApoTome microscope. The magnification of cells was 630-fold. 


\subsection{Subcellular fractionation and immunoprecipitation analyses}

\subsubsection{General strategy for optimization of co-immunoprecipitation analysis}

In preparation of co-immunoprecipitation experiments, LoVo, TM3 and HEK293 cells were transiently transfected with $\mathrm{rAbcb} 7$ and $\mathrm{rAbcb} 6$ expression plasmids yielding tagged transporter proteins. To be sure of expression of fluorescent (EGFP-tagged) fusion protein, transfected cells were inspected via fluorescence microscopy (fig. 20). Approximately 2 3\% of LoVo cells expressed an EGFP-tagged fusion protein. Therefore, HEK293 cells, known from the literature to generally exhibit a high transfection efficiency, were also used for the co-immunoprecipitation studies. However, even in HEK293 cells rAbcb6-EGFP was expressed to a greater extent than rAbcb7-EGFP fusion protein (fig. 20). 

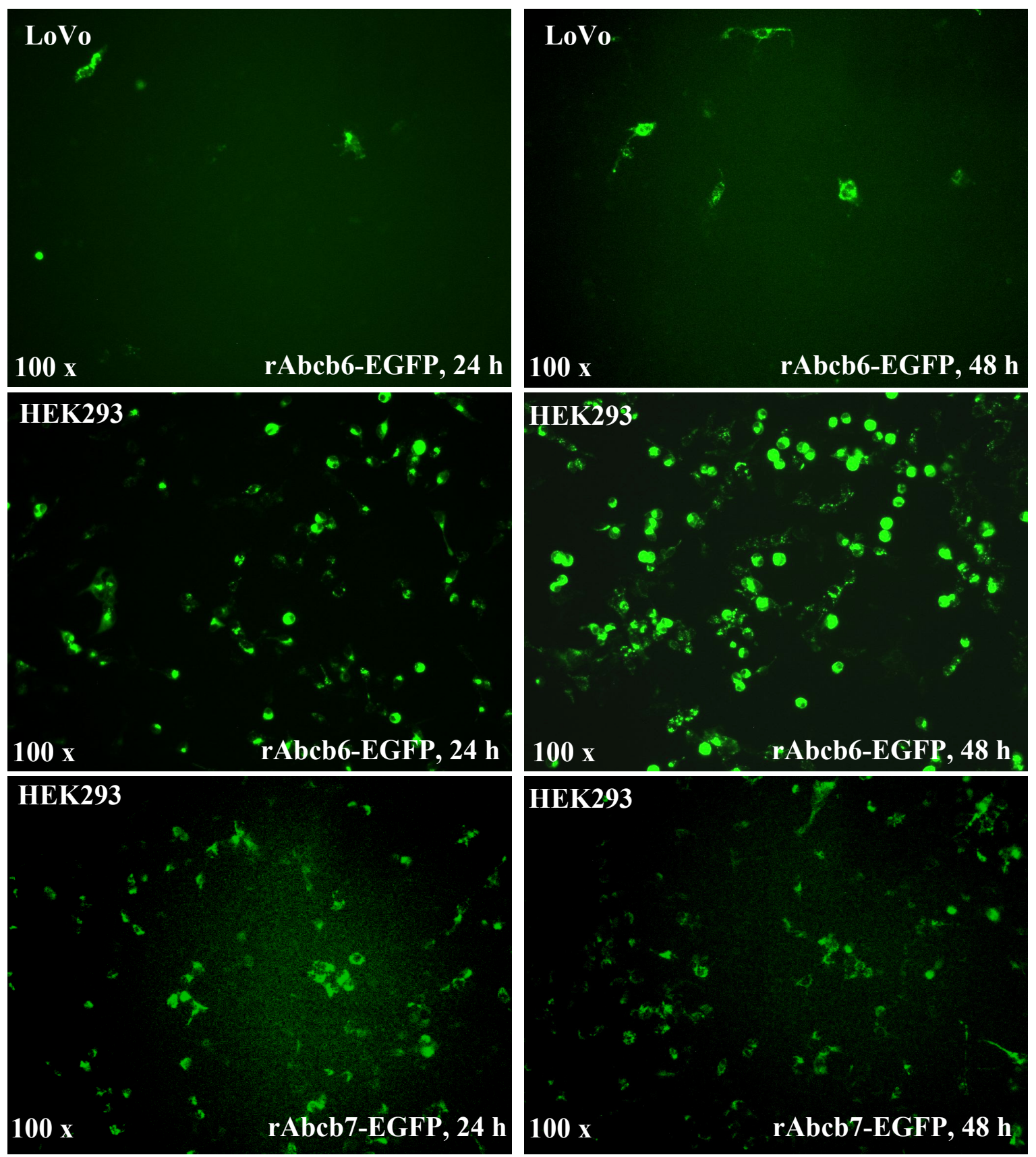

Figure 20. Expression of rAbcb6-EGFP and rAbcb7-EGFP fusion proteins in transiently transfected LoVo and HEK293 cells, observed at $\mathbf{1 0 0}$-fold magnification. A higher percentage of HEK293 expressed EGFP-tagged proteins than of LoVo cells. Furthermore, the expression of rAbcb6-EGFP fusion protein was higher than the expression of rAbcb7-EGFP in HEK293 cells. 
The following steps were necessary to gain material for the immunoprecipitation. The cells, expressing tagged transporter proteins, were harvested $48 \mathrm{~h}$ after transfection, homogenized and subjected to subcellular fractionation (chapter 2.2.16.1). To optimize the conditions for the immunoprecipitation, fractions containing the largest amount of transporter protein were to be used. To define the subcellular fractions that contained the highest amounts of rAbcb6/rAbcb7 protein, Western blots of all subcellular fractions were performed prior to the immunoprecipitation experiments. The extent of rAbcb6-EGFP-dependent fluorescence, as compared to rAbcb7-EGFP-dependent fluorescence in transfected cells, was used as a basis to define a loading amount of rAbcb6- versus rAbcb7- containing protein fractions for preliminary Western blot analyses. A loading ratio of 1:3 for LoVo cells or 1:15 for HEK293 cells of rAbcb6 to rAbcb7 containing protein fractions was applied for PAGE gel analyses (chapter 2.2.16.4 and 2.2.16.5). As an antibody for detection of transporter proteins among other cellular proteins in the Western blots, the horseradish peroxidase (HRP) conjugated antibody against the V5 epitope was used. Due to the anti-V5 antibody conjugation to HRP no secondary antibody was necessary. That allowed to obtain images of Western blots with a very low background. Detection of transporter proteins (rAbcb6/rAbcb7-V5) with anti-V5 antibody showed that the highest accumulation of rAbcb6-V5 was in the fraction obtained at $18,000 \mathrm{x} g$ centrifugation and that the $\mathrm{rAbcb} 7-\mathrm{V} 5$ fusion protein was enriched in the fraction sedimented at 10,000 x g (fig. 21). 


\section{LoVo cells, expressing: rAbcb6-V5 rAbcb7-V5}

\section{$\begin{array}{llllllllllllll}\text { Std } & N & M & F & S & N & M & F & S\end{array}$}

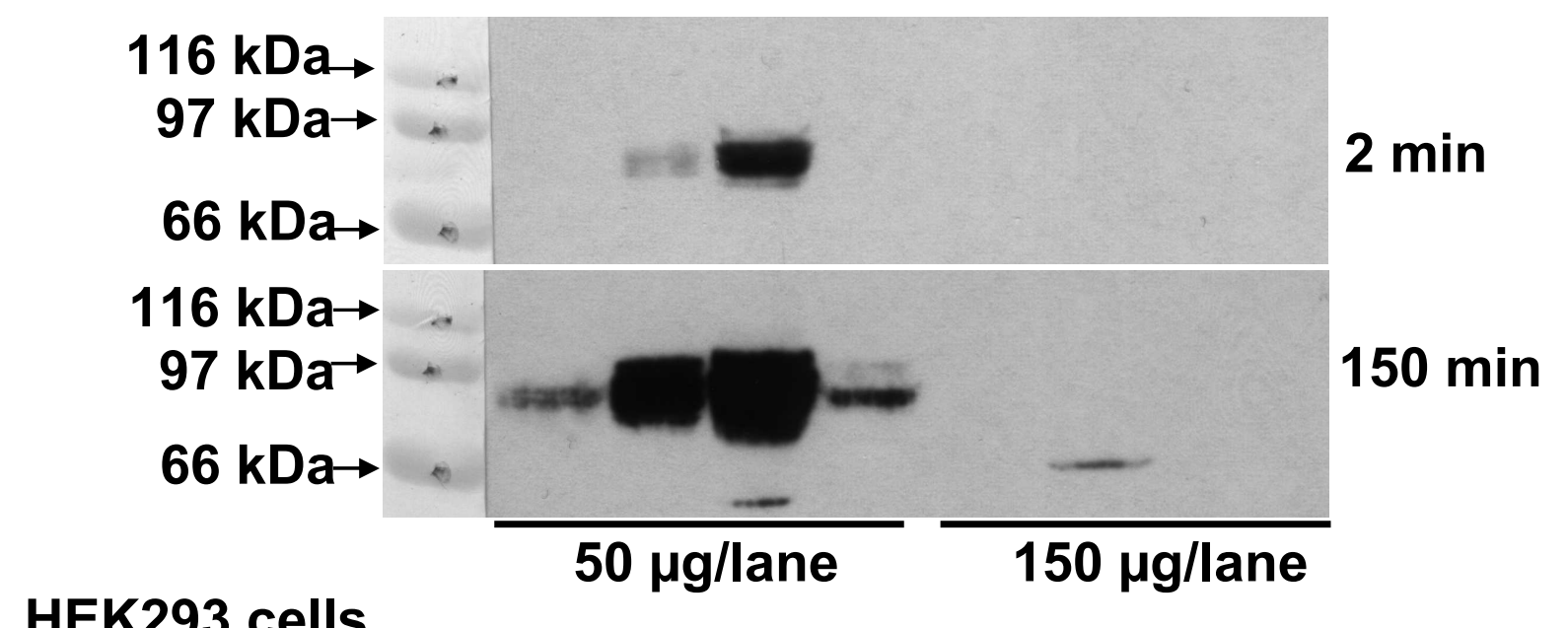

HEK293 cells, expressing: rAbcb6-V5

rAbcb7-V5

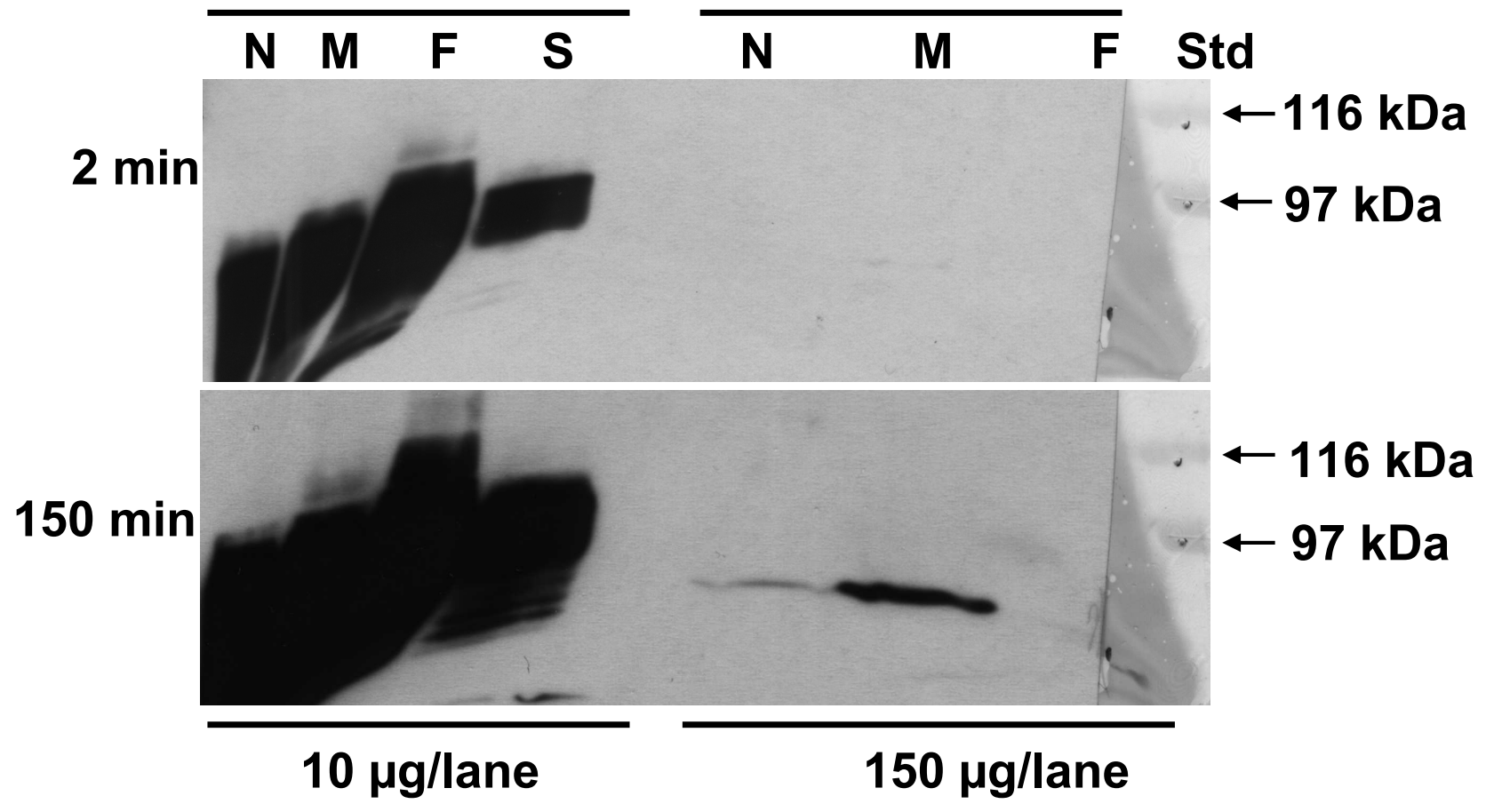

Figure 21. Expression of V5 epitope-tagged rAbcb6 and rAbcb7 proteins in subcellular fractions of transiently transfected LoVo and HEK293 cells. The subcellular fractions were obtained via centrifugation at $600 \times \mathrm{g}(\mathrm{N}), 10,000 \times \mathrm{g}(\mathrm{M}), 18,000 \times \mathrm{g}(\mathrm{F})$ as described in the experimental procedure. The cytosolic fraction (S) was also loaded. The $80-105 \mathrm{kDa}$ rAbcb6-V5 protein was mostly found in the subcellular fraction sedimented at $18,000 \mathrm{x} \mathrm{g}$ (F), whereas the $70 \mathrm{kDa}$ rAbcb7-V5 fusion protein was detected in the subcellular fraction enriched with mitochondrial proteins (M) in LoVo and in HEK293 cells. The molecular weight range protein standard (Std) was visualized as described in chapter 2.2.16.5.2. Two film exposures of the Western blots are shown ( 2 min and $150 \mathrm{~min}$ ). 
Depending on the purpose, $200-1,000 \mu \mathrm{g}$ of total protein from one of these two fractions were later used per immunoprecipitation (chapter 2.2.16.3) with an antibody against EGFP (anti-GFP full length) or an anti-V5 antibody (chapter 2.1.7.2). The obtained precipitate was washed, heated to disrupt the antibody/antigen/protein A complex and the precipitated transporters were resolved via SDS polyacrylamide gel electrophoresis (chapter 2.2.16.4.1). Proteins were transferred onto PVDF membranes (chapter 2.2.16.5.1) and the blot was subjected to immunochemical analysis (chapter 2.2.16.5.3) with HRP-conjugated anti-V5 or with an anti-GFP/EGFP antibody. The outline of the co-immunoprecipitation procedure is depicted in figure 22.

\subsubsection{Characterization of tagged rAbcb6 and rAbcb7 protein expression in subcellular fractions}

The V5-tagged rAbcb6 or rAbcb7 fusion proteins were characterized in fractions obtained from LoVo and HEK293 cells, transiently co-transfected with EGFP- and V5-tagged rAbcb6 or rAbcb7 fusion proteins coding vectors (chapter 2.2.14.2). The EGFP tag of fusion proteins allowed to observe directly the fusion protein expression in the cells (fig. 20) via fluorescence microscopy (chapter 2.2.15.2). The V5-tagged rAbcb7 and rAbcb6 proteins were visualized in Western blot with the HRP-conjugated anti-V5 antibody (fig. 21).

The calculated masses of the 895 amino acids long rAbcb6-V5 and 799 amino acids long rAbcb7-V5 were $98.4 \mathrm{kDa}$ and $87.7 \mathrm{kDa}$, respectively. rAbcb6-V5 fusion protein was detected as a wide band of $80-105 \mathrm{kDa}$ in protein fractions extracted from cells transfected with the rAbcb6-V5 encoding vector and sedimented at 18,000 x g. By contrast, rAbcb7-V5 fusion protein was detected as a fine narrow band of approximately $70 \mathrm{kDa}$ (after extended film exposure) in the fraction of rAbcb7-V5 expressing cells that was sedimented at $10,000 \mathrm{x}$ g (fig. 21). This LoVo fraction was formerly shown to be enriched in mitochondrial protein (Abdul Jalil, 2004), for example, in cytochrome C oxidase protein. The experimentally detected electrophoretic mobility of $\mathrm{rAbcb} 7-\mathrm{V} 5$ corresponding to $70 \mathrm{kDa}$, was lower than the expected $87.7 \mathrm{kDa}$. However, this is in accordance with the $66 \mathrm{kDa}$ band of the 752 amino acid human $\mathrm{ABCB} 7$ protein, detected with an antiserum raised against the human $\mathrm{ABCB} 7$ nucleotide binding domain (Csere et al. 1998): the V5 tag in rAbcb7-V5 would be expected 
to account for $4.95 \mathrm{kDa}$ of the rAbcb7-V5 fusion protein. Adding about $5 \mathrm{kDa}$ to the apparent weight of the human (untagged) ABCB7 protein would amount to roughly $71 \mathrm{kDa}$. The strongest rAbcb6-V5 band was observed in the 18,000 $\mathrm{xg}$ fraction (F-fraction), which is in accordance with the results obtained by Abdul Jalil (2004). The prolonged exposure of the blots to an ECL film showed that the antibody-antigen complexes were formed also in fractions enriched with mitochondria, nuclei and cytosolic proteins. This might be due to technical limitations for obtaining $100 \%$ pure organelle membrane fractions via homogenization and centrifugation. Along this line, the HEK293 cells showed a higher transfection efficiency and thus a higher percentage of rAbcb7-V5 was expressed by the cells and resulted in the appearance of the rAbcb7-V5 band also in the $600 \times \mathrm{g}(\mathrm{N})$ fraction to a slight extent (fig. 21).

The subcellular fractionation showed that the most extensive rAbcb6-V5 and rAbcb7-V5 fusion protein expression occurred in different subcellular fractions: rAbcb7-V5 was preferentially detected in the fraction enriched with mitochondrial proteins, whereas the highest rAbcb6-V5 amount was found in the protein fraction sedimented by centrifugation at $18,000 \mathrm{x}$ g. This is in accordance with the data obtained from fluorescence microscopy analysis of fusion protein expression and argues against strict rAbcb6 and rAbcb7 colocalization. Thus the possibility of transporter homodimerization was considered.

\subsubsection{Detection of protein-protein interaction via co-immunoprecipitation}

To test the hypothesis of rAbcb6 homodimerization, the LoVo, HEK293 and TM3 cells were transiently co-transfected with rAbcb6-EGFP and rAbcb6-V5 encoding vectors (chapter 2.2.14). The rAbcb6-EGFP fusion protein expression was controlled via the fluorescence microscope and cells were used for fractionation followed by the PAGE gel analysis. The protein fraction sedimented at $18,000 \mathrm{x} \mathrm{g}$ was subsequently used for co-immunoprecipitation as described in chapter 3.4.1. The outline of co-immunoprecipitation is schematically depicted in figure 22. The rAbcb6-V5 protein was co-immunoprecipitated with rAbcb6EGFP and vice versa in all three lines of cells (fig. 22 and 23). 

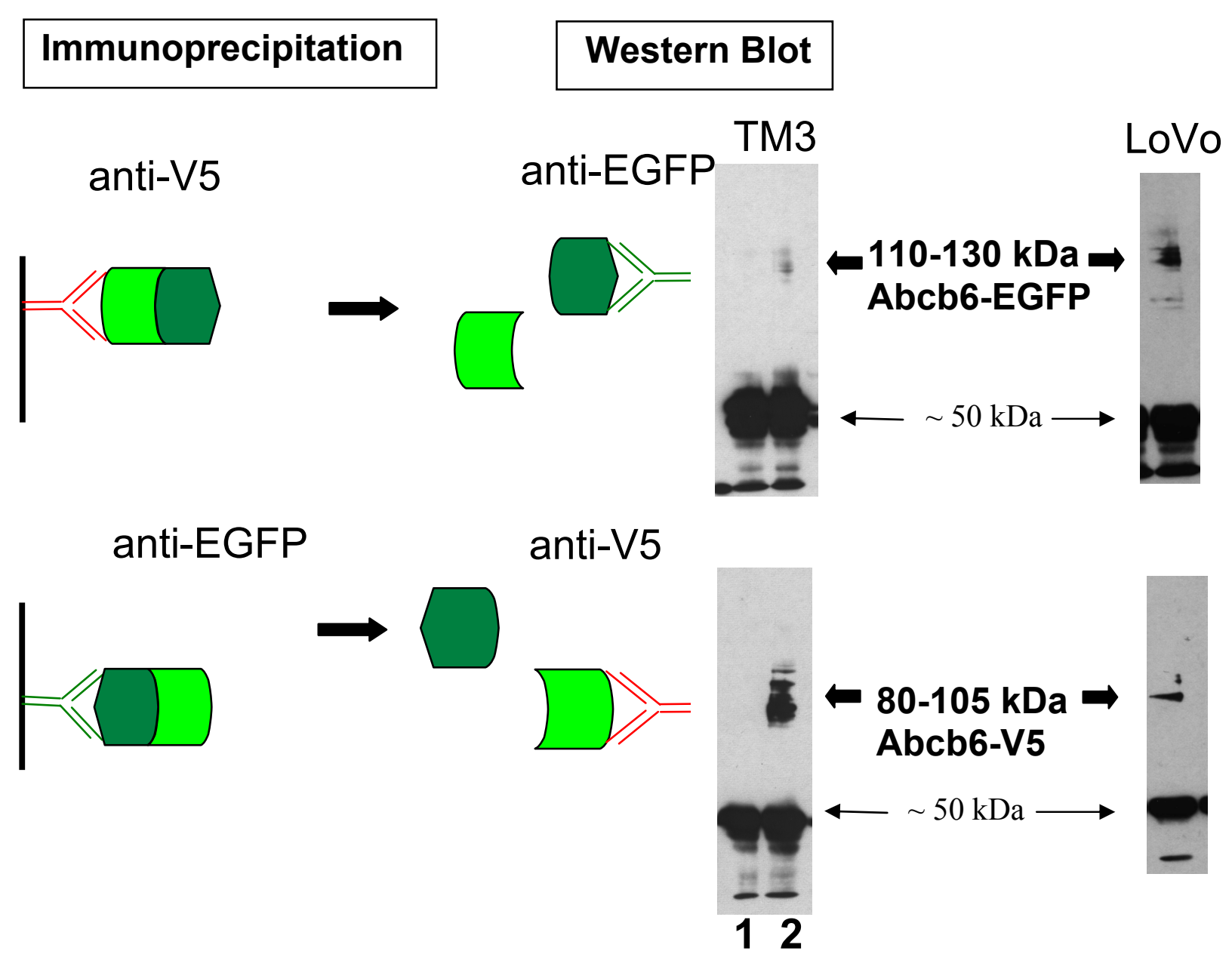

Figure 22. Outline of the co-immunoprecipitation experiment and coimmunoprecipitation of rAbcb6-V5 and rAbcb6-EGFP from fractions of TM3 and LoVo cells transiently co-transfected with rAbcb6-EGFP and rAbcb6-V5 encoding vectors. The proteins precipitated with the anti-V5 antibody immunoreacted with the antiEGFP antibody and vice versa in TM3 and LoVo cells. For both cell systems, the fraction precipitated at $18,000 \times \mathrm{g}$ was used for immunoprecipitation. The TM3 cells were transfected in parallel with a Puc19 plasmid (1) as a negative control in comparison to rAbcb6 coimmunoprecipitation (2). The protein at approximately $50 \mathrm{kDa}$ represents immunoglobulin heavy chains that are present in the sample applied to the electrophoresis gel due to the immunoprecipitation procedure. 


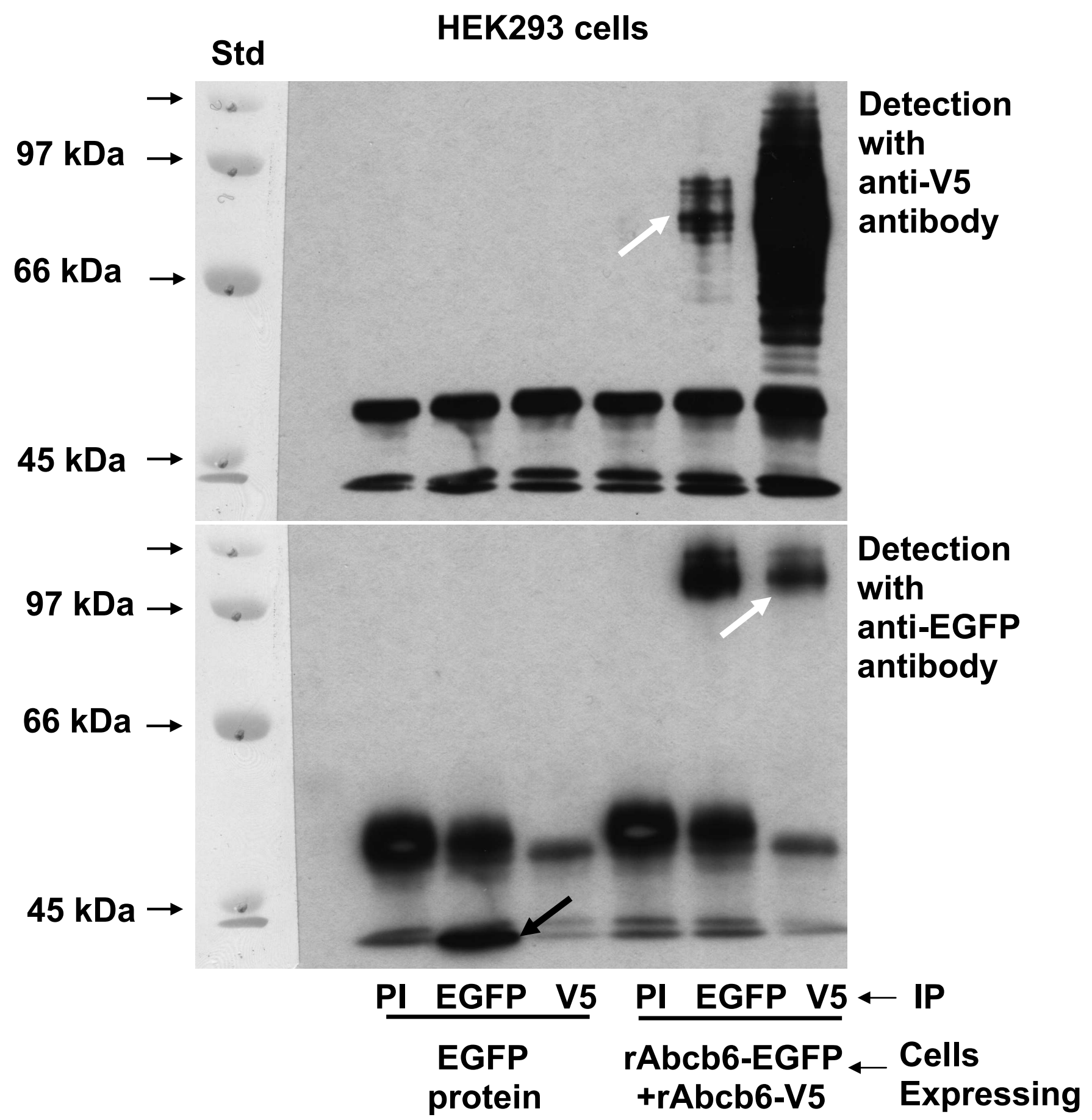

Figure 23. Co-immunoprecipitation of rAbcb6-EGFP and rAbcb6-V5 from the 18,000 $x$ g fraction of HEK293 cells transiently co-transfected with rAbcb6-EGFP and rAbcb6V5 encoding vectors. The proteins immunoprecipitated (IP) with the anti-V5 antibody immunoreacted with the anti-EGFP antibody and vice versa in the HEK293 cells. White arrows indicate the band detected as a result of the co-immunoprecipitation. The black arrow points to the band yielded by the EGFP protein $(\sim 26.5 \mathrm{kDa})$. The HEK293 cells were transfected in parallel with a pEGFP-N1 vector as an additional negative control of coimmunoprecipitation. The high molecular weight range protein standard (Std) was visualized as described in chapter 2.2.16.5.2. 
The rAbcb7 homodimerization with itself was tested by transiently co-transfecting LoVo and HEK293 cells with rAbcb7-EGFP and rAbcb7-V5 coding vectors (chapter 2.2.14.2). In parallel, LoVo cells were co-transfected with rAbcb6-EGFP and rAbcb6-V5 coding vectors as a positive control and HEK293 were transfected with pEGFP-N1 vector as a negative control for the co-immunoprecipitation. Transfected cells were used for fractionation 48 hours after the co-transfection. The immunoprecipitation was performed with the $10,000 \times \mathrm{g}$ (mitochondrial) fraction for rAbcb7-V5/rAbcb7-EGFP and with the 18,000 x $\mathrm{g}$ fraction for rAbcb6-V5/rAbcb6-EGFP. Precipitated protein detection in Western blot was performed with HRP-conjugated anti-V5 antibody. The overnight exposure of the blot to the ECL film resulted in a very weak band and in a strong band of approximately $70 \mathrm{kDa}$ in blots made from HEK293 and LoVo cell fractions, respectively. The bands were detected in the lanes loaded with the proteins precipitated with the antibody against the full-length GFP protein (reacting with EGFP). This indicated that the rAbcb7 could form homodimers with itself (fig. 24 and 25). In LoVo system, a weak band of $80-105 \mathrm{kDa}$ (rAbcb6-V5) was observed in the lane loaded with rAbcb6-EGFP and rAbcb6-V5 containing fraction, precipitated with the antibody against EGFP, thus indicating that the co-immunoprecipitation functioned well (fig. 24). 


\section{LoVo cells}

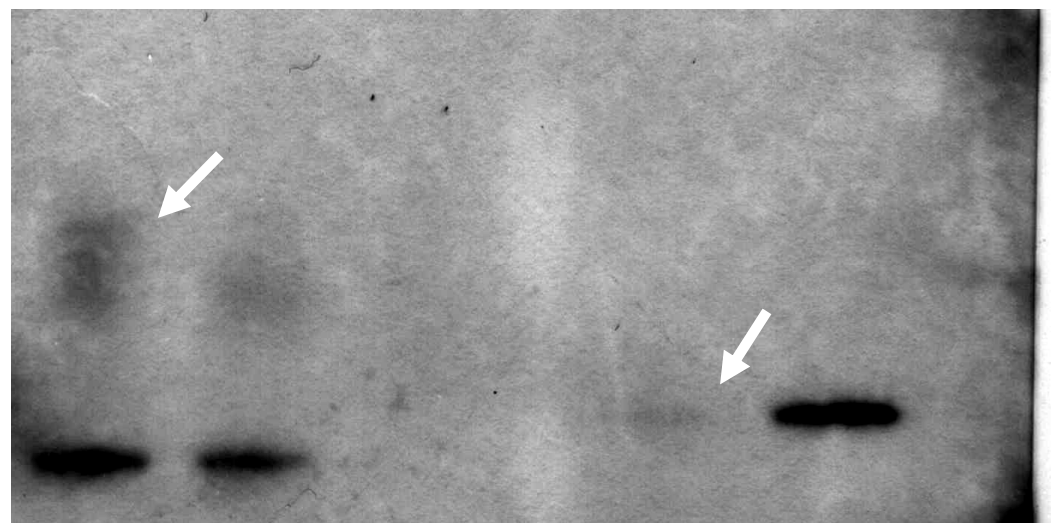

EGFP V5 PI

rAbcb6-EGFP

+rAbcb6-V5

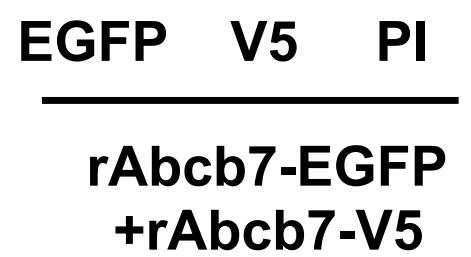

\section{Std}

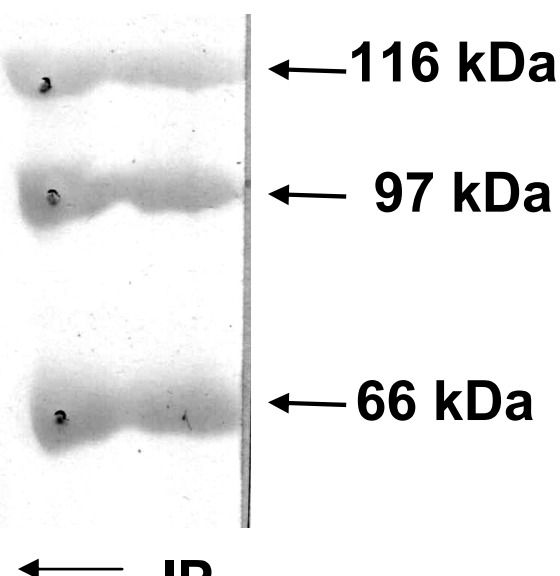

Figure 24. Co-immunoprecipitation of V5- and EGFP-tagged rAbcb7 proteins from the LoVo fraction enriched in mitochondrial proteins $(10,000 \times \mathrm{g}$ fraction). LoVo cells, transiently co-transfected with rAbcb7-EGFP and rAbcb7-V5 or rAbcb6-EGFP and rAbcb6V5 expression plasmids, were homogenized and subjected to subcellular fractionation. Antibodies used for immunoprecipitation (IP) were directed against the tag proteins (EGFP and V5, respectively). To immunoprecipitate the rAbcb6-tagged protein, $400 \mu \mathrm{g}$ proteins of the fraction sedimented at $18,000 \mathrm{x} g$ were used, whereas for $\mathrm{rAbcb} 7$ precipitation $1000 \mu \mathrm{g}$ of proteins sedimented at 10,000 $\mathrm{x} g$ were utilized. The Western blot was developed with the anti-V5 antibody. White arrows indicate rAbcb7-V5 (weak $70 \mathrm{kDa}$ band) and rAbcb6-V5 (80-105 kDa), co-immunoprecipitated with EGFP-tagged rAbcb7 and rAbcb6, respectively. The immunoprecipitation with the pre-immune serum (PI) served as a negative control for co-immunoprecipitation. The immunoprecipitation with anti-V5 antibody (V5) served as a positive control for the band detection with the anti-V5 antibody in Western blot. The bands detected at approximately $60 \mathrm{kDa}$ might be due to rAbcb6-V5 partial degradation, because these bands were not detected in samples precipitated with pre-immune serum or in samples containing only tagged $\mathrm{rAbcb} 7$ proteins. The high molecular weight range protein standard (Std) was visualized as described in chapter 2.2.16.5.2. 


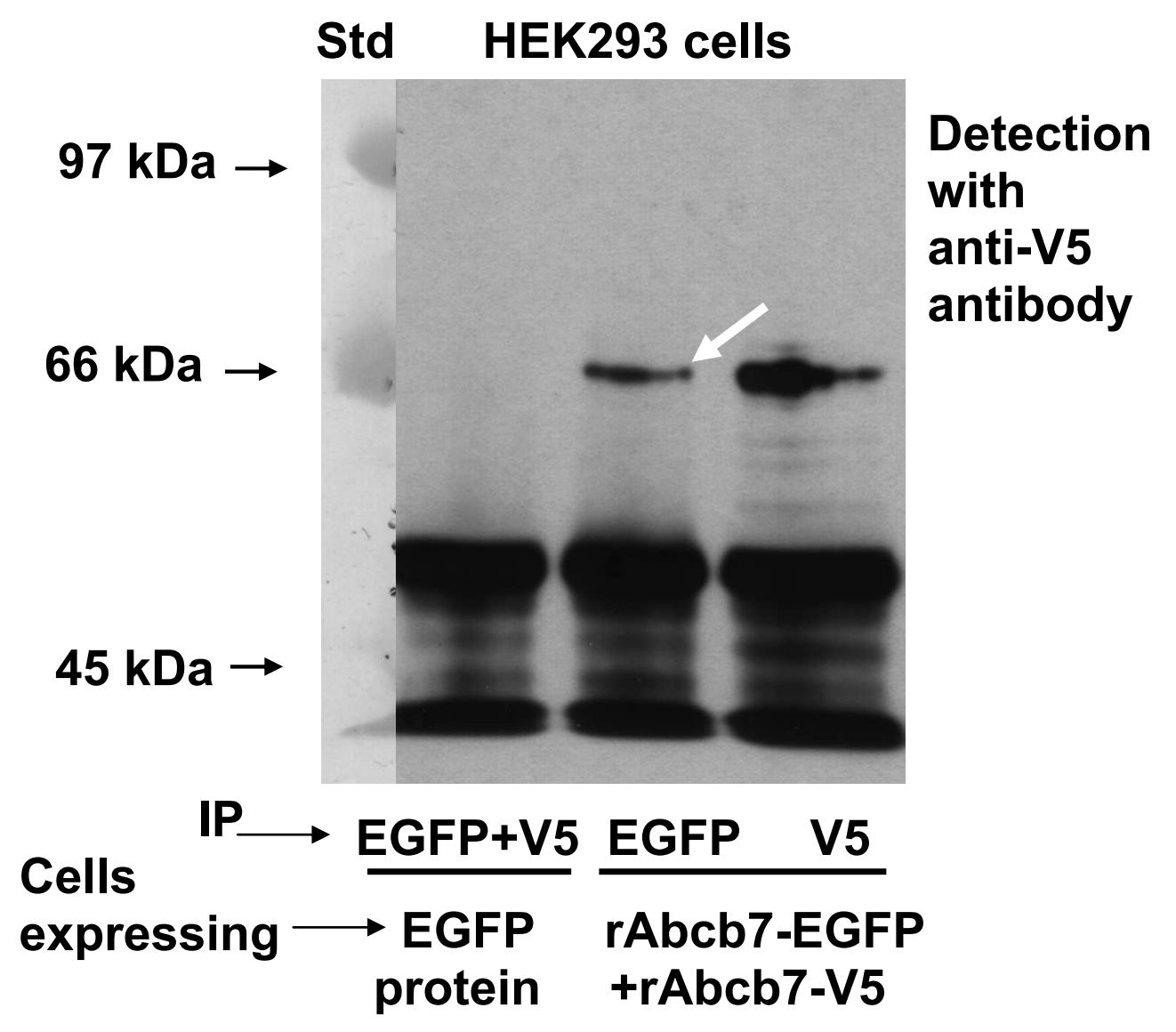

Figure 25. Co-immunoprecipitation of V5- and EGFP-tagged rAbcb7 protein from the HEK293 cell fraction enriched in mitochondrial proteins. The cells, transiently cotransfected with rAbcb7-EGFP and rAbcb7-V5 encoding vectors, were homogenized and fractionated $48 \mathrm{~h}$ after transfection. For immunoprecipitation (IP) with antibodies against the EGFP and V5 tags, 1,400 $\mu \mathrm{g}$ of proteins from fraction sedimented at 10,000 x g were used per antibody. The white arrow points to the approximately $70 \mathrm{kDa}$ rAbcb7-V5 fusion protein co-immunoprecipitated with rAbcb7-EGFP using the anti-EGFP antibody. The positive (EGFP) control, an immunoprecipitation and detection of rAbcb7-V5 fusion protein with the anti-V5 antibody (V5) in the Western blot yielded a band of about $70 \mathrm{kDa}$ as expected. No band, corresponding to EGFP protein, was detected in the negative control lane loaded with the mitochondrial fraction proteins (sedimented at $10,000 \mathrm{x} \mathrm{g}$ ), obtained from EGFPexpressing cells, after immunoprecipitation with anti-V5 and anti-EGFP (GFP+V5). This indicates that the co-immunoprecipitation was specific. The high molecular weight range protein standard (Std) was visualized as described in chapter 2.2.16.5.2. 
Western blot analysis showed that rAbcb6-V5 fusion protein was most abundant in the $18,000 \mathrm{x} \mathrm{g}$ fraction. However, it was also detectable in the fraction enriched with mitochondrial proteins (fig. 21). Thus, the possibility of rAbcb6 heterodimerization with rAbcb7 protein was also checked via co-immunoprecipitation, using the mitochondrial fraction. For this purpose, LoVo cells were transiently co-transfected with rAbcb6-EGFP and rAbcb7-V5 encoding vectors (chapter 2.2.14.2). The cell co-transfection with rAbcb6-V5 and rAbcb6-EGFP encoding vectors was performed as a positive control for the coimmunoprecipitation. Forty eight hours after transfection, the cells were fractionated and the relative levels of tagged proteins were defined via Western blot. $500 \mu \mathrm{g}$ of total protein from the fraction sedimented at $10,000 \mathrm{x} g$ were used per immunoprecipitation with an antibody against the EGFP tag protein, with an anti-V5 antibody (chapter 2.1.7.2) or with a preimmune serum (obtained from the rabbit prior to its immunization with the rAbcb6 peptide) (negative control). After immunoprecipitation, samples were subjected to PAGE gel analysis followed by Western blot production. The blot exposure to the ECL film yielded no band to be detected by the HRP-conjugated anti-V5 antibody in the LoVo protein samples containing rAbcb7-V5 and rAbcb6-EGFP fusion proteins, precipitated with the anti-EGFP antibody (fig. 26). A faint rAbcb6-V5 band was detected in the lane, loaded with the positive control sample that was precipitated with antibody against the full-length EGFP tag protein (fig. 26), confirming that rAbcb6-V5 co-immunoprecipitation with rAbcb6-EGFP occurred. As a further positive control, rAbcb7-V5 was both immunoprecipitated and detected in the Western blot with the V5-antibody. Thus, under applied experimental conditions, coimmunoprecipitation between rAbcb6-EGFP and rAbcb7-V5 was not detected. However, a lower expression of $\mathrm{rAbcb} 7-$ as compared to rAbcb6-tagged proteins (comparing immunoprecipitated rAbcb6-V5 to rAbcb7-V5 bands in fig. 26) might have hampered the

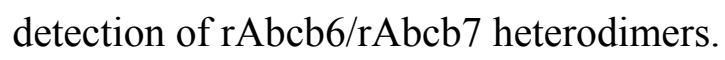




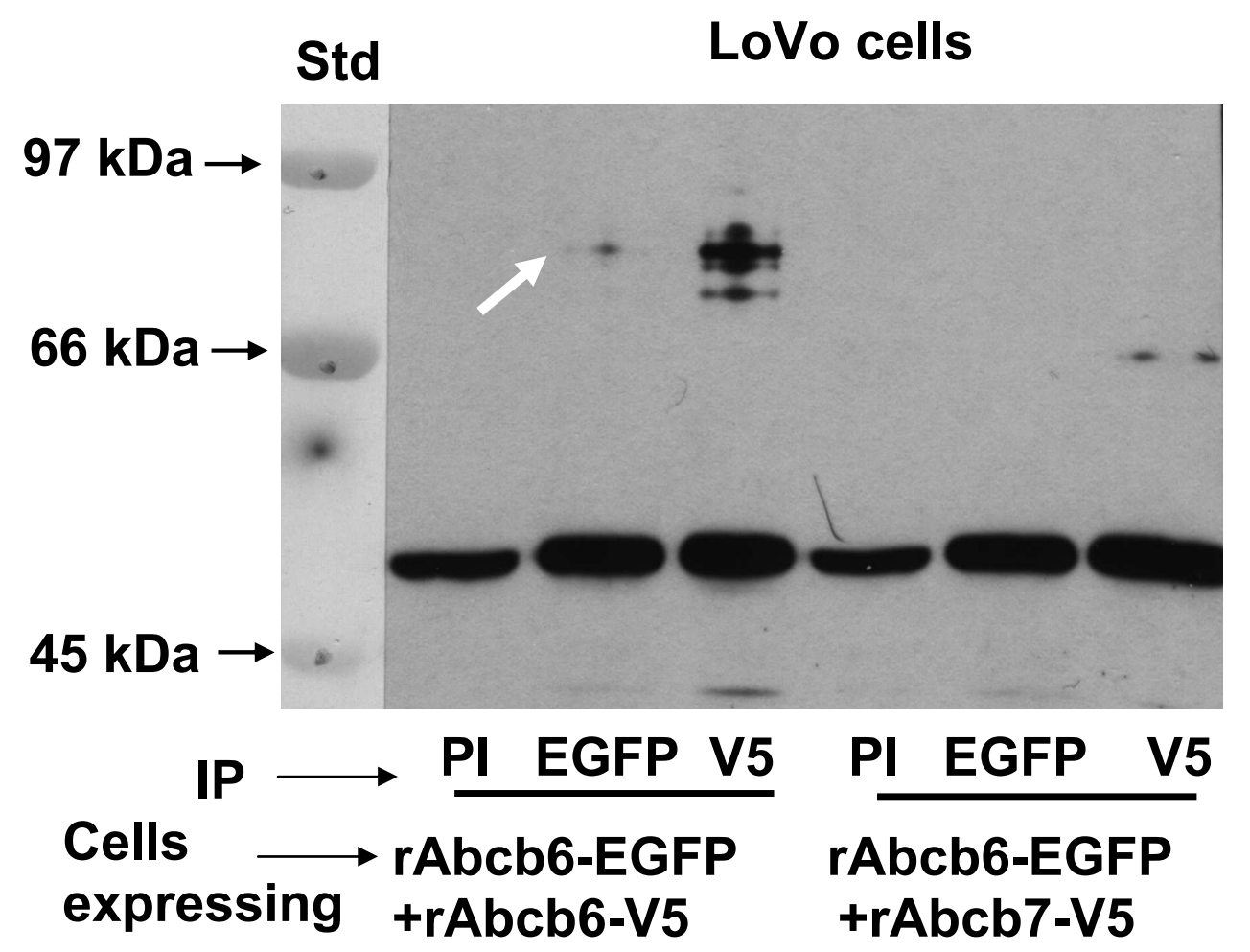

Figure 26. Immunoprecipitation experiments performed with LoVo cell fractions received from cells expressing V5- and EGFP-tagged rAbcb7 and rAbcb6 proteins. The cells were transiently co-transfected with EGFP-/V5-tagged rAbcb7 and rAbcb6 expression vectors and subjected to subcellular fractionation. Using $10,000 \mathrm{x} g$ fraction, the immunoprecipitation (IP) was performed with pre-immune serum (PI), with the anti-V5 antibody (V5) and with the antibody against the EGFP. No co-immunoprecipitation of rAbcb7-V5 with rAbcb6-EGFP from the mitochondrial protein enriched fraction was observed. As a positive control for the co-immunoprecipitation, LoVo cells were cotransfected in parallel with rAbcb6-EGFP and rAbcb6-V5 encoding vectors. The arrow indicates the co-immunoprecipitated rAbcb6-V5 with rAbcb6-EGFP in LoVo cells. The high molecular weight range protein standard $(\mathrm{Std})$ was visualized as described in chapter 2.2.16.5.2. 


\section{Discussion}

Rat Abcb6 (rAbcb6) is a half-transporter that is expected to require a dimerization partner to be able to perform its function. The identification of the putative dimerization partner for rAbcb6 was the main goal of this work. To enable expression of tag-labelled rAbcb6 and the tag-labelled rAbcb7 (a potential dimerization partner), rAbcb7 was cloned and rAbcb6 was re-cloned. The distribution of rAbcb6 mRNA expression in rat hepatocytes and tissues was compared to rAbcb7 mRNA distribution. The subcellular distribution of both half transporter proteins was investigated in transfected cell lines via fluorescence microscopy and immunological analyses of subcellular fractions obtained by differential centrifugation. Finally, immunoprecipitation analysis, involving differentially tagged rAbcb6 and rAbcb7, was performed to identify the dimerization partners.

\subsection{Re-cloning of the rAbcb6 sequence}

The full coding cDNA sequence of rAbcb6 was originally identified via RT-PCR and 5'- and 3'-end RACE-PCR approaches using total RNA extracted from male Wistar rat hepatocytes (Hirsch-Ernst et al. 1998). For the present thesis, the rAbcb6 cDNA sequence was re-cloned via RT-PCR, again from total RNA obtained from male Wistar rat hepatocytes. Apart from clones corresponding to the rAbcb6 reference sequence, clones exhibiting consistent deviations were isolated. Fourteen single nucleotide changes, as compared to the reference sequence, were found to be dispersed within the coding rAbcb6 sequence (chapter 3.1.2 of this work). Eleven out of 14 single nucleotide changes found in the coding sequence of rAbcb6 resulted in amino acid changes in the derived rAbcb6 protein sequence (chapter 3.1.2). These changes were not restricted to a single rat as a donor for hepatocytes. Furthermore, the use of different polymerase enzymes indicated that these changes were probably not due to errors in nucleotide incorporation. RNA editing might be considered as an explanation for the single nucleotide changes detected in the rAbcb6 cDNA sequence. RNA editing is a RNA processing event, often resulting in amino acid sequence changes upon translation of mRNA (Herbert \& Rich, 1999). The most recently discovered type of RNA editing is an adenine to inosine $(\mathrm{a} \rightarrow \mathrm{i})$ modification in premature mRNA, with inosine acting as guanine during translation to a protein (Maas et al. 2002). The deamination of adenosine to inosine is carried out by different double-stranded RNA (dsRNA)-specific 
adenosine deaminases (ADARs). The $\mathrm{a} \rightarrow \mathrm{i}$ RNA editing is physiologically of great importance. Lethal phenotypes were observed in $\mathrm{ADAR} 1^{+/}$chimeric mouse embryos and $\mathrm{ADAR}^{-/-}$mice died young after repeated episodes of epileptic seizures, probably due to underediting of glutamate receptor RNA (Maas et al. 2002). The inosine (i), obtained via deamination of adenosine, is converted to guanine $(\mathrm{g})$ during reverse transcription of the mRNA to the cDNA sequence, yielding an $\mathrm{a} \rightarrow \mathrm{g}$ change. Five $\mathrm{a} \rightarrow \mathrm{g}$ transitions were found in the rAbcb6 cDNA and four of them resulted in amino acid changes in the derived rAbcb6 protein sequence. Thymine to cytosine $(t \rightarrow c)$ changes comprised the majority of changes found in the rAbcb6 cDNA sequence. This form of RNA editing involved uridine conversion to cytosine $(\mathrm{u} \rightarrow \mathrm{c})$ by amination (Smith et al. 1997). Casey et al. demonstrated that hepatitis delta virus infectivity depended on good functioning of the $\mathrm{u} \rightarrow \mathrm{c}$ editing mechanism within the host cell (Casey et al. 1992). Later, $\mathrm{u} \rightarrow \mathrm{c}$ editing was detected in the mRNA of the Wilms tumor suppressor gene WT1 (Sharma et al. 1994).

Another explanation for the 14 single nucleotide changes in the cDNA sequence of rAbcb6 might be the assumption that these changes occurred in genomic DNA, resulting in single nucleotide polymorphisms (SNPs). Most SNPs detected in other examined genes of the human $\mathrm{ABCB}$ subfamily were localized outside the coding sequence, in the introns (Saito et al. 2002). SNPs are evolutionarily stable and when occurring in coding regions of genomic DNA, might account for the phenotypic differences between populations within one species. The C3435T SNP detected in exon 26 of the MDR1 gene (a silent alteration not leading to a change in the amino acid sequence) was demonstrated to be associated with lowered intestinal P-glycoprotein expression in Caucasian populations, but this association appears to be generally reversed in Japanese (Ho et al. 2005). To investigate the possibility that 14 single nucleotide changes detected in rAbcb6 cDNA sequence might be SNPs, genomic rAbcb6 DNA must be extracted from a statistically reliable number of rats and sequenced. 


\subsection{Subcellular localization of rAbcb6}

Rat Abcb6 (rAbcb6) mRNA expression analysis (Northern blot) revealed that rAbcb6 was ubiquitously expressed in all rat organs analyzed, with the greatest extent of the expression in testis. This experimental result is in accordance with the Northern blot studies published previously (Hirsch-Ernst et al. 1998).

The subcellular localization of rAbcb6 protein was investigated in LoVo (human colon adenocarcinoma) cells and in TM3 cells (a mouse cell line exhibiting a phenotype of testicular Leydig cells). These cell lines were transfected with expression vectors bearing cDNA of rAbcb6-EGFP or rAbcb6-DsRed2 fusion proteins. In both cell systems, tagged rAbcb6 showed co-localization with the lysosomal/late endosomal marker Lamp1, whereas no substantial co-localization was observed in cells co-expressing rAbcb6 and the fluorescent mitochondrial marker protein (mitochondrial targeting sequence of cytochrom $\mathrm{C}$ oxidase subunit VIII-DsRed). These results were in accordance with the ones obtained via subcellular fractionation analysis and immunocytochemistry performed by Abdul Jalil in LoVo cells expressing native or V5-tagged rAbcb6 protein (Abdul Jalil, 2004). A previous paper (Mitsuhashi et al. 2000) provided evidence that human ABCB6 might be co-localized with granular worm-like mitochondrial structures. The subcellular fractionation studies of LoVo cells expressing tagged and non-tagged rAbcb6 (Abdul Jalil, 2004) and the subcellular co-localization studies performed with the fluorescent protein-tagged rAbcb6 protein (present study, chapter 3.3.3) oppose to the mitochondrial localization (suggested by Mitsuhashi et al. (2000) for the human protein) and argue for a lysosomal/late endosomal localization of rAbcb6.

\section{3 rAbcb7 cloning, mRNA expression and protein characterization}

To examine possible rAbcb6 and rAbcb7 heterodimerization and to be able to construct expression vectors for $\mathrm{rAbcb} 7$, the full coding sequence of $\mathrm{rAbcb} 7$ was cloned and deposited in the EMBL database under accession number AJ621255.

In Northern blot experiments two rAbcb7 mRNA transcripts (approximately 6.9 and $3.0 \mathrm{~kb}$ ) were detected. This is in line with the two transcripts of mAbcb7, an orthologue in mouse, shown in Northern blots of murine samples (Savary et al. 1997). A major rAbcb7 transcript of approximately $6.9 \mathrm{~kb}$ was in accordance with a major mAbcb7 transcript of $6.5 \mathrm{~kb}$. The 3 
$\mathrm{kb}$ mRNA transcripts were found in both species. The presence of two transcripts of rodent Abcb7 might be due to different processes, like alternative RNA splicing and/or different promoter usage.

The Northern blot analysis revealed that $\mathrm{rAbcb} 7$ was ubiquitously expressed in rat tissues with the highest expression in heart tissue. The expression level of both, 6.9 and $3 \mathrm{~kb}$ rAbcb7 mRNA transcripts decreased in rat hepatocytes under the cultivation conditions. It was initially assumed that this decrease might be due to oxidative stress in hepatocytes during culture. However, treatment of hepatocytes with the antioxidant $\mathrm{N}$-acetyl-L-cysteine did not decrease the down-regulation of rAbcb7 mRNA during culture (data not shown), arguing against a pivotal role of oxidative stress in down-regulation.

Csere et al. (1998) described the localization of human ABCB7 protein to the mitochondria. Due to high sequence homology between human ABCB7 and rat rAbcb7, rAbcb7 was expected to co-localize with the mitochondrial marker. This was confirmed by observing the fluorescence of rAbcb7-EGFP and mitochondrial marker proteins in living HEK293 and fixed LoVo cells. An immunoreactive rAbcb7-V5 band in Western blots corresponding to a mobility of $70 \mathrm{kDa}$, was detected in subcellular fractions enriched with mitochondrial proteins, supporting the assumption of rAbcb7 localization to the mitochondria.

A functional $\mathrm{ABC}$ transporter contains two TM and two NBF domains. The deduced rAbcb7 protein sequence contained only one TM and one NBF, indicating that rAbcb7 is a halftransporter. The $\mathrm{rAbcb} 7$ protein shares $43 \%$ amino sequence identity with the mitochondrial half-transporter Atm1p of Saccharomyces cerevisiae. Chloupkova et al. investigated the possibility that Atm1p might homodimerize with itself via co-expression of V5- and HAtagged Atm1p in a $\triangle$ atm1 yeast strain. Tagged proteins were co-immunoprecipitated with antibodies against HA- and V5-tags, demonstrating that Atm1p indeed formed a homodimer (Chloupkova et al. 2004). Due to its relationship to mitochondrial Atm1p, the hypothesis was raised that $\mathrm{rAbcb} 7$ might also form a homodimer. To test this hypothesis, LoVo and HEK293 cells were transiently co-transfected with rAbcb7-EGFP and rAbcb7-V5 encoding vectors. The immunoprecipitation of the cellular fraction, enriched in mitochondria with antibodies against EGFP and V5 tags, was followed by the fusion protein detection in Western blot with the anti-V5 antibody. The experiment yielded a weak band of rAbcb7-V5 in LoVo and a strong band in HEK293 for the sample, which had been subjected to immunoprecipitation by the antibody against EGFP, indicating that rAbcb7-V5 was co-immunoprecipitated with rAbcb7-EGFP. This result supports the rAbcb7 homodimerization hypothesis. 


\section{4 rAbcb6 dimerization partner}

Rat rAbcb6 is a recently identified $\mathrm{ABC}$ half-transporter which has been suggested to participate in biometal homeostasis (Hirsch-Ernst et al. 1998). rAbcb6 is closely related to the Atm1p half-transporter found in Saccharomyces cervisiae (39\% amino acid sequence identity). This gave rise to the idea that rAbcb6 might dimerize with itself. This hypothesis was tested by co-expressing V5- and EGFP-tagged rAbcb6 protein in 3 cell systems: LoVo, HEK293 and TM3. The EGFP- and V5-tagged rAbcb6 proteins were found to coimmunoprecipitate. These results support the conclusion that rAbcb6 forms a transporter complex by homodimerization.

Up to date several cases of obligatory heterodimerization of $\mathrm{ABC}$ half-transporters belonging to the same subfamily have been extensively described in the literature: human ABCG5 was shown to heterodimerize with ABCG8 (Graf et al. 2003) and TAP1 was shown to heterodimerize with TAP2 (Kelly et al. 1992), to be able to perform their function. Although the tagged rAbcb6 protein tends to homodimerize (as indicated by this thesis), the possibility of its heterodimerzation with another member of the $\mathrm{ABCB}$ subfamily cannot be a priori excluded. Information obtained from the literature regarding $\mathrm{ABC}$ half-transporters indicates that two half-transporters must be sufficiently similar in sequence to form functional dimers. Furthermore, two putative dimerization partners would be expected to co-localize when coexpressed in living systems. The rAbcb6 human orthologue ABCB6 shares $41 \%$ amino acid sequence identity with the human $\mathrm{ABCB} 7$. Moreover, ABCB6 has been described to functionally complement defective yeast Atm1p in yeast (Mitsuhashi et al. 2000). Csere et al. (1998) provided evidence that the human ABCB7 protein can also functionally complement defective yeast Atm1p. The result that both, human ABCB6 and ABCB7, were able to functionally complement Atm1p, suggested that they might fulfill similar functions. One explanation could involve complementation by dimer formation of the expressed halftransporters with each other. The experiments made by Csere et al. and Mitsuhashi et al., regarding the human half-transporters, gave rise to the idea of possible heterodimerization of rat proteins, rAbcb6 and rAbcb7.

However, during the work on this thesis, several lines of evidence were obtained that do not support the rAbcb6 heterodimerization with rAbcb7 hypothesis.

(1) Although the Northern blot analyses showed that rAbcb6 and rAbcb7 mRNAs were ubiquitously expressed in all rat organs, but the highest expression of rAbcb7 mRNA was in heart, whereas rAbcb6 mRNA was most abundant in testis. Additionally, the expression 
level of rAbcb7 mRNA decreased within the cultivation time of rat hepatocytes, whereas the one of rAbcb6 mRNA remained constant throughout the cultivation period.

(2) The subcellular co-localization studies performed with differentially tagged rAbcb6 and rAbcb7 proteins in cell culture showed no substantial co-localization of the two proteins. Furthermore, the tagged rAbcb6 was observed to co-localize with the lysosomal/late endosomal marker Lamp1. This result is in accordance with evidence on the localization of V5-tagged and native rAbcb6 provided by Abdul Jalil (2004).

(3) In Western blot studies, performed with fractionated cell homogenates from HEK293 and LoVo cells expressing tagged rAbcb6 or rAbcb7, the $80-105$ kDa rAbcb6-V5 and the 110$130 \mathrm{kDa}$ rAbcb6-EGFP proteins were mostly found in the subcellular fraction sedimented at $18,000 \mathrm{x}$ g. By contrast, the approximately $70 \mathrm{kDa}$ rAbcb7-V5 protein was detected mainly in the subcellular fraction sedimented at $10,000 \mathrm{x}$ g. Besides, the rAbcb6-V5 and rAbcb6EGFP fusion proteins were visualized in Western blot as a diffuse band that is characteristic for glycosylated proteins (Abdul Jalil, 2004), whereas the rAbcb7-V5 protein resulted in a fine thin band.

To determine whether the rAbcb6 and rAbcb7 may form a heterodimer, coimmunoprecipitation experiments were performed with LoVo cells co-expressing rAbcb6EGFP and rAbcb7-V5 fusion proteins. The protein fraction sedimented at 10,000 x $\mathrm{g}$ was used under the assumption that potential interaction should be studied in a fraction containing both potential interaction partners. Although the $10,000 \mathrm{x} g$ fraction was not the major rAbcb6-containing fraction, it still contained relatively high amounts of rAbcb6 and the highest amount of rAbcb7 fusion protein, as shown by Western blot. The coimmunoprecipitation experiment yielded no evidence of rAbcb6-EGFP heterodimerization with rAbcb7-V5. However, it should be considered that rAbcb7 expression in transfected cells was relatively low as compared to rAbcb6 expression. The generally weak rAbcb7 expression in LoVo and in HEK293 cells may be due to the interference of rAbcb7 protein over-expression with critical cell functions. According to the results of RT-PCR, a relatively sensitive method used to detect the presence of mRNA via reverse transcription and PCR, both LoVo and HEK293 cells endogenously expressed ABCB7 mRNA. ABCB6 mRNA was endogenously produced by HEK293 cells, but was not detected in LoVo cells. Yet, the expression of rAbcb6-EGFP fusion protein was greater in HEK293 than in LoVo cells, indicating that the expression level of fusion protein did not necessarily depend on the presence or absence of the endogenous protein. The overall unequal expression of tagged rAbcb6 and rAbcb7 might have hampered detection of their heterodimerization in LoVo 
cells. On the other hand, the use of the mitochondrial fraction (with low rAbcb6 abundance and high rAbcb7 abundance) would have been expected to diminish the influence of unequal tagged rAbcb6 and rAbcb7 protein expression. Although further experiments with cells expressing sufficient and approximately equal amounts of both, rAbcb6 and rAbcb7, are required to rule out that co-immunoprecipitation might occur, it appears unlikely that rAbcb6 heterodimerization with $\mathrm{rAbcb} 7$ should be of relevance in establishment of full transporter complexes.

\subsection{Implications for $\mathrm{rAbcb6}$ and $\mathrm{rAbcb} 7$ function and future perspectives}

The human ABCB6 sequence similarity to Atmlp of Saccharomyces cerevisiae, and its functional complementation of the defective Atm1p in yeast cells (Mitsuhashi et al. 2000) were the reasons to assume that human ABCB6 and its orthologues in other species, for example rAbcb6 in rat, might be involved in $[\mathrm{FeS}]$ cluster transport and cellular iron homeostasis. In the mean time, several lines of evidence have appeared that further implicate a possible rAbcb6 function in cell protection against metal-dependent toxicity.

(1) rAbcb6 protein shares a greater amino acid sequence identity to vacuolar Hmtlp (heavy metal tolerance protein 1) of Schizosaccharomyces pombe (44.5\%) than to the mitochondrial Atm1p of Saccharomyces cerevisiae (39\%).

(2) The experimental rAbcb6 subcellular localization results obtained by Abdul Jalil (2004) and supported by the present work indicate that rAbcb6 is associated with vesicular structures, probably representing lysosomes/late endosomes, but not with mitochondria. It is in line with the localization of Hmtlp in the vacuolar compartment in fission yeasts. The yeast vacuolar compartment is regarded as corresponding to the lysosomal one in higher eukaryotic cells.

(3) Hmtlp appears to confer tolerance towards cadmium toxicity by transporting cadmium bearing phytochelatin complexes into the vacuole. Hirsch-Ernst et al. (2001) found that LoVo cells expressing rAbcb6 exhibited moderate tolerance towards $\mathrm{Cu}^{2+}$ when the copper was applied as $\mathrm{CuSO}_{4}$, indicating that rAbcb6 may confer protection of cells against toxic effects of copper (Abdul Jalil et al., manuscript prepared for submission).

Rat Abcb6 (rAbcb6) exhibits an 88\% amino acid sequence identity to its human orthologue ABCB6. Experimental evidence, provided by Mitsuhashi et al. (2000), implicates human ABCB6 participation in cellular iron homeostasis. Due to the existence of multiple 
connections between cellular copper and iron metabolism, rAbcb6 might affect both, iron and copper, homeostasis (Abdul Jalil et al., manuscript prepared for submission).

The rAbcb7 half transporter is related to Atm1p (43\% amino acid sequence identity) of Saccharomyces cerevisiae and human ABCB7 (92\% amino acid sequence identity), a mitochondrial half-transporter. An essential function of mitochondria is to supply [FeS] clusters to the cytosol (reviewed by Napier et al. 2005), and evidence was obtained that both, Atm1p and ABCB7, are involved in intracellular iron homeostasis and maturation of cytosolic iron/sulfur cluster proteins (Kispal et al. 1997, Csere et al. 1998). The participation of human $\mathrm{ABCB} 7$ in cellular iron homeostasis was supported by the discovery that mutations occurring in the ABCB7 nucleotide sequence cause XLSA/A (X-linked sideroblastic anemia with ataxia), a disease resulting in mitochondrial iron accumulation in erythrocyte precursors (Allikmets et al. 1999). The subcellular co-localization studies displayed in the present thesis demonstrated a mitochondrial localization of rAbcb7. The rAbcb7 amino acid sequence similarity to the yeast Atm1p and to human $\mathrm{ABCB} 7$ and its mitochondrial localization implicate $\mathrm{rAbcb} 7$ participation in iron homeostasis of rat cells.

Further studies are required to clearly define the substrates of rAbcb6 and rAbcb7, indicating that this is going to be a main aim for future work on the two half transporter proteins. The knowledge on subcellular localization and dimerization constellations constitutes an important basis for planning and optimizing investigations on transporter protein structure and function. Site-specific mutagenesis of $\mathrm{rAbcb7/rAbcb6}$ nucleotide sequences would be a method to be used to clarify structure-function relationships. 


\section{Summary}

Rat Abcb6 (rAbcb6) is an ABC half transporter of the ABCB subfamily and is expected to require a dimerization partner to perform its function. The main aim of this thesis was to detect a dimerization partner of rAbcb6. Due to sequence homology between human ABCB7 and $\mathrm{ABCB} 6$, rat $\mathrm{Abcb} 7$ was considered as a putative dimerization partner for rAbcb6. rAbcb6 cDNA had been cloned before (Hirsch-Ernst et al. 1998), but the full coding rAbcb7 cDNA was unknown. During the re-cloning of the rAbcb6 cDNA sequence, besides the wild-type sequence, cDNAs were consistently found, exhibiting in total 14 single nucleotide changes as compared to the reference rAbcb6 cDNA EMBL database sequence. Whether these changes might represent single nucleotide polymorphisms or might be a consequence of RNA editing, remains to be resolved. The full length coding rAbcb7 cDNA was cloned for the first time and deposited in the EMBL database under accession number AJ621255. Comparison of rAbcb6 and rAbcb7 mRNA expression showed that rAbcb7 was most abundantly expressed in heart, whereas rAbcb6 expression was highest in testis, although both showed ubiquitous expression in rat organs. Proteins deduced from rAbcb6 and rAbcb7 cDNA sequences demonstrated $41 \%$ amino acid sequence identity. Expression vectors yielding rAbcb6-EGFP, rAbcb6-V5, rAbcb6-DsRed2, rAbcb7-EGFP, rAbcb7-V5 and rAbcb7-DsRed2 fusion proteins were constructed.

LoVo cells were transiently co-transfected with rAbcb6-EGFP and rAbcb7-DsRed2 encoding vectors and the distribution of fluorescent fusion protein tags (EGFP; DsRed2) was observed via fluorescence microscopy. No substantial co-localization was detected between green fluorescent rAbcb6-EGFP and red fluorescent rAbcb7-DsRed2. Moreover, the tagged rAbcb6 protein yielded a punctated pattern, whereas tagged rAbcb7 protein exhibited a vermiform pattern. Further experiments provided evidence that the distribution pattern of V5-, EGFP- and DsRed2-tagged rAbcb6 and rAbcb7 was tag independent.

Cells of two different cell lines, TM3 and LoVo, were transiently co-transfected with rAbcb6-EGFP protein encoding vector and organelle marker protein encoding vector (DsRed-tagged mitochondrial marker or lysosomal/late endosomal marker Lamp1-DsRed). Almost no co-localization was observed between rAbcb6-EGFP and the mitochondrial marker protein, but in both cell lines the rAbcb6-EGFP distribution pattern showed a considerable overlap with Lamp1-DsRed. 
On the other hand, rAbcb7-EGFP was found to co-localize with the mitochondrial marker in LoVo and HEK293 cells, expressing both rAbcb7-EGFP and fluorescent mitochondrial marker.

Western blot analyses of fractionated cell homogenates containing tagged rAbcb7 or tagged rAbcb6 revealed that $\mathrm{rAbcb} 7-\mathrm{V} 5$ (with an electrophoretic mobility corresponding to $70 \mathrm{kDa}$ ) was enriched in the fraction sedimented at $10,000 \times \mathrm{g}$, whereas the majority of rAbcb6-V5 $(80-105 \mathrm{kDa})$ or rAbcb6-EGFP $(110-130 \mathrm{kDa})$ was found in the fraction sedimented at $18,000 \times \mathrm{g}$.

rAbcb6-EGFP and rAbcb6-V5 fusion proteins were co-immunoprecipitated from extracts of transiently transfected TM3, LoVo and HEK293 cells. Similarly, rAbcb7-EGFP and rAbcb7V5 were found to co-immunoprecipitate in LoVo and HEK293 cells, indicating that rAbcb6 and rAbcb7 form homodimers. However, no evidence was obtained for coimmunoprecipitation of rAbcb6 and $\mathrm{rAbcb} 7$ fusion proteins, although other experiments need to be performed to rule out that low rAbcb7 protein expression levels might be a limiting factor.

The presented results are in line with a vesicular, probably late endosomal/lysosomal localization of rAbcb6 and a mitochondrial localization of rAbcb7. The immunoprecipitation experiments suggest that these two proteins form homodimers. However, it appears unlikely that proteins localized in different subcellular compartments, like rAbcb6 in lysosomes/late endosomes and $\mathrm{rAbcb} 7$ in mitochondria, would form heterodimers. 


\section{List of references}

1. Abdul Jalil Y. Subzelluläre Lokalisation des „ATP-binding-cassette” (ABC)Transporters Abcb6/ABCB6 (,umat: ubiquitously expressed mammalian $A B C$ halftransporter"). Dissertation zur Erlangung des Doktorgrades der Medizinischen Fakultät der Georg-August-Universität, Göttingen. Göttingen 2004.

2. Abdul Jalil Y., Ritz V., Jakimenko A., Schmitz-Salue Ch., Awuah D., Kotthaus A., Kietzmann T., Ziemann Ch., Hirsh-Ernst K.I. Subcellular localization of rat Abcb6, an ATP-binding cassette half-transporter involved in transition metal homeostasis. Manuscript prepared for submission.

3. Abele R., Tampè R. Modulation of antigen transport machinery TAP by friends and enemies. FEBS Letters 2006. 580:1156-1163

4. Allikmets R., Gerrard B., Hutchinson A., Dean M. Characterization of the human ABC superfamily: isolation and mapping of 21 new genes using the expressed sequence tags database. Hum. Mol. Genet. 1996. 5:1649-1655

5. Allikmets R., Raskind W.H., Hutchinson A., Schueck N.D., Dean M., Koeller D.M. Mutation of a putative mitochondrial iron transporter gene (ABC7) in X-linked sideroblastic anemia and ataxia (XLSA/A). Human Mol. Genetics 1999. 5:743-749

6. Allikmets R., Singh N., Sun H., Shroyer N.F., Hutchinson A., Chidambaram A., Gerrard B., Baird L., Stauffer D., Peiffer A., Rattner A., Smallwood P., Li Y., Anderson K.L., Lewis R.A., Nathans J., Leppert M., Dean M., Lupski J.R. A photoreceptor cell-specific ATP-binding transporter gene (ABCR) is mutated in recessive Stargardt macular dystrophy. Nat. Genet. 1997. 15:236-246

7. Berry M.N., Friend D.S. High yield preparation of isolated rat liver parenchymal cells. J. Cell. Biol. 1969. 43:506-520

8. Birnboim H.C., Doly J. A rapid alkaline extraction procedure for screening recombinant plasmid DNA. Nucleic Acids Res. 1979. 24:1513-1523

9. Bisbal C., Martinand C., Silhol M., Lebleu B., Salehzada T. Cloning and characterization of a RNAse L inhibitor. A new component of the interferon-regulated 2-5 A pathway. J. Biol. Chem. 1995. 270:13308-13317

10. Borst P., and Oude Elferink R. Mammalian ABC transporters in health and disease. Annu. Rev. Biochem. 2002. 71:537-592

11. Broccardo C., Luciani M., Chimini G. The ABCA subclass of mammalian transporters. Biochim. Biophys Acta 1999. 1461:395-404 
12. Casey J.L., Bergmann K.F., Brown T.L., Gerin J.L. Structural requirements for RNA editing in Hepatitis $\delta$ Virus: evidence for a uridine-to-cytidine editing mechanism. Proc. Nat. Acad. Sci. 1992. 89:7149-7153

13. Chloupkova M., Reaves S.K., LeBard L.M., Koeller D.M. The mitochondrial ABC transporter Atm1p functions as a homodimer. FEBS Letters 2004. 569:65-69

14. Chomczynski P., and Sacchi N. Single-step method of RNA isolation by acid guanidinium thiocyanate-phenol-chloroform extraction. Analyt. Biochem. 1987. 162:156-159

15. Csere P., Lill R., Kispal G. Identification of human mitochondrial ABC transporter, the functional orthologue of yeast Atm1p. FEBS Letters 1998. 441:266-270

16. Dean M., Hamon Y., and Chimini G. The human ATP-binding Cassette (ABC) transporter superfamily. J. Lipid Res. 2001. 42:1007-1017

17. Dean M., Rzhetsky A., and Allikmets R. The human ATP-binding Cassette (ABC) transporter superfamily. Genome Research 2001. 11:1156-1166

18. Decottignies A., and Goffeau A. Complete inventory of the yeast ABC proteins. Nature genetics. 1997. 15:137-145

19. Deeley R.G., Cole S.P.C. Substrate recognition and transport by multidrug resistance protein 1 (ABCC1). FEBS Letters 2006. 580:1103-1111

20. Drewinko B., Yand L.Y. Restriction of CEA synthesis to the stationary phase of growth of cultured human colon carcinoma cells. Exp. Cell. Res. 1976. 101: 414-416

21. Frelet A., Klein H. Insight in the eukaryotic $A B C$ transporter function by mutation analysis. FEBS Letters 2006. 580:1064-1084

22. Frohman M.A. On beyond classic RACE (rapid amplification of cDNA ends). PCR Methods Appl. 1994. 4:40-58

23. Gatmaitan Z.C., Nies A.T., Arias I.M. Regulation and translocation of ATP-dependent apical membrane proteins in rat liver. Am. J. Physiol. 1997. 272:1041-1049

24. Gerloff T., Stieger B., Hagenbuch B., Madon J., Landmann L., Roth J., Hofmann A.F., Meier P.J. The sister of P-glycoprotein represents the canalicular bile salt export pump of mammalian liver. J. Biol. Chem. 1998. 273:10046-50

25. Glavinas H., Krajesi P., Cserepes J., Sarkadi B. The role of ABC transporters in drug resistance, metabolism and toxicity. Curr Drug Deliv. 2004. 1:27-42

26. Gottesman M.M., Fojo T., Bates S.E. Multidrug resistance in cancer: role of ATPdependent transporters. Nat. Rev. Cancer 2002. 2:48-58 
27. Graf G.A., Yu L., Li W.-P., Gerard R., Tuma P.L., Cohen J.C., Hobbs H.H. ABCG5 and ABCG8 are obligate heterodimers for protein trafficking and biliary cholesterol excretion. J. Biological Chemistry 2003. 278:48275-48282

28. Graham F.L., Smiley J., Russell W.C., Nairn R. Characteristics of a human cell line transformed by DNA from human adenovirus type 5. J. Gen. Virol. 1977. 36:59-74

29. Hayashi H., Takada T., Suzuki H., Onuki R., Hofmann A.F., Sugiyama Y. Transport by vesicles of glycine- and taurine- conjugated bile salts and taurolithocholate 3-sulfate: a comparison of human BSEP with rat Bsep. Biochim. Biophys. Acta 2005. 1738:54-62

30. Herbert A., Rich A. RNA processing and the evolution of eukaryotes. Nat. Genet. 1999. 21:265-269

31. Hirsch-Ernst K.I., Abdul Jalil Y., Schmitz-Salue C. Elucidation of the function of the ABC half-transporter Umat employing Umat-transfected LoVo colon carcinoma cell lines. Naunyn Schmiedebergs Arch. Pharmacol. 2001. 363: symp. R160

32. Hirsch-Ernst K.I., Gaini-Rahimi S., Ernst B.-P., Schmitz-Salue C., Blume S., and Kahl G.F. Molecular cDNA cloning and tissue distribution of mRNA encoding a novel ATPBinding Cassette (ABC) half-transporter. Biochemical and Biophysical research communications 1998. 249:151-155

33. Ho G.-T., Soranzo N., Nimmo E.R., Tenesa A., Goldstein D.B., Satsangi J. ABCB1/MDR1 gene determines susceptibility and phenotype in ulcerative colitis: discrimination of critical variants using a gene-wide haplotype tagging approach. Hum. Mol. Genet. 2006. 16:797-805

34. Hoffann B., Piasecki A., Paul D. Proliferation of fetal rat hepatocytes in response to growth factors and hormones in primary culture. J. Cell Physiol. 1989. 139:654-662

35. Hopfner K.P., Tainer J.A. Rad50/SMC proteins and ABC transporters: unifying concepts from high-resolution structures. Curr. Opin. Struct. Biol. 2003. 13:249-255

36. Hung L.-W., Wang I.X., Nikaido K., Liu P.-Q., Ames G.F.-L., Kim S.-H. Crystal structure of the ATP-binding subunit of an ABC transporter. Nature 1998. 396:703-707

37. Juliano R.L., Ling V. A surface glycoprotein modulating drug permeability in Chinese hamster ovary cell mutants. Biochim. Biophys Acta 1976. 455:152-62

38. Kelly A., Powis S.H., Kerr L.A., Mockridge I., Elliott T., Bastin J., Uchanska-Ziegler B., Ziegler A., Trowsdale J., Towsend A. Assembly and function of the two ABC transporter proteins encoded in the human major histocompatibility complex. Nature 1992. 355:641644

39. Koopmann J.O., Post M., Neefjes J.J., Hammerling G.J., Momburg F. Translocation of long peptides by transporters associated with antigen processing (TAP). Eur. J. Immunol. 1996. 26:1720-1728 
40. Kyhse-Andersen J. Electroblotting of multiple gels: a simple apparatus without buffer tank for rapid transfer of proteins from polyacrylamide to nitrocellulose. J. Biochem. Biophys. Methods 1984. 10:203-209

41. Laemmli U.K. Cleavage of structural proteins during assembly of the head of bacteriophage T4. Nature 1970. 227:680-685

42. Lee C.H., Bradley G., Zhang J.T., Ling V. Differential expression of P-glycoprotein genes in primary rat hepatocyte culture. J. Cell Physiol. 1993. 157:392-402

43. Leslie E.M., Deeley R.G., Cole S.P.C. Multidrug resistance proteins: role of Pglycoprotein, MRP1, MRP2 and BCRP (ABCG2) in tissue defense. Tox. And Appl. Pharm. 2005. 204:216-237

44. Lill R., Kispal G. Mitochondrial ABC transporters. Res Microbiol. 2001. 152:331-340

45. Locher K.P., Lee A.T., Rees D.C. The E. coli BtuCD structure: a framework for ABC transporter archtecture and mechanism. Science 2002. 296:1091-1098

46. Lowry O.H., Rosebrough N., Farr L.A., Randall R.J. Protein measurement with the folin phenol reagent. 1951. 265-275

47. Maas S., Rich A., Nishikura K. A-to-I RNA editing: recent news and residual mysteries. J. Biol. Chem. 2003. 278:1391-1394

48. Mather J.P. Establishment and characterization of two distinct mouse testicular epithelial cell lines. Biol. Reprod. 1980. 23:243-252

49. Melaine N., Satie A.-P., Lassurguere J., Desmots S., Jegou R., Samson M. Molecular cloning of several rat $\mathrm{ABC}$ transporters including a new transporter, Abcb8, and their expression in rat testis. Int. J. of Androl. 2005.

50. Mitsuhashi N., Miki T., Senbongi H., Yokoi N., Yano H., Miyazaki M., Nakajima N., Iwanaga T., Yokoyama Y., Shibata T., and Seino S. MTABC3, a novel mitochondrial ATP-binding Cassette protein involved in iron homeostasis. J. Biological Chemistry 200. Vol. 275. 23:17536-17540

51. Napier I., Ponka P., Richardson D.R. Iron trafficking in the mitochondrion: novel pathways revealed by disease. BLOOD 2005. 105:1867-1874

52. Nikaido H. How are the ABC transporters energized? PNAS. July, 2002. vol.99. 15:9609-9610

53. Ortiz D.F., Kreppel L., Speiser D.M., Scheel G., McDonald G., Ow D.W. Heavy metal tolerance in the fission yeast requires an ATP-binding cassette-type vacuolar membrane transporter. J. EMBO 1992. 11:3491-3499

54. Richard M., Drouin R., Beaulieu A.D. ABC50, a novel human ATP-binding cassette protein found in tumor necrosis factor- $\alpha$-stimulated synoviocytes. Genomics 1998. $53: 137-145$ 
55. Ross D.D., Yang W., Abruzzo L.V., Dalton W.S., Schneider E., Lage H., Dietel M., Greenberger L., Cole S.P., Doyle L.A. Atypical multidrug resistance: breast cancer resistance protein messenger RNA expression in mitoxantrone-selected cell lines. J. Natl. Cancer Inst. 1999. 91:429-433

56. Saito S., Iida A., Sekine A., Miura Y., Ogawa C., Kawauchi S., Higuchi S., Nakamura Y. Three hundred twenty-six genetic variations in genes encoding nine members of ATPbinding cassette, subfamily B (ABCB/MDR/TAP), in the Japanese population. J. Hum. Genet. 2002. 47:38-50

57. Sanger F., Nicklen S., Coulson A.R. DNA sequencing with the chain terminating inhibitors. Proc. Natl. Acac. Sci. U.S.A. 1977. 5463-5467

58. Savary S., Allikmets R., Denizot F., Luciani M.-F., Mattei M.-G., Dean M., Chimini G. Isolation and chromosomal mapping of a novel ATP-binding cassette transporter conserved in mouse and human. Genomics 1997. 41:275-278

59. Schinkel A.H., Mayer U., Wagenaar E., Mol C.A., van Deemter L., Smit J.J., van der Valk M.A., Voordouw A.C., Spits H., van Tellingen O., Zijlmans J.M., Fibbe W.E., Borst P. Normal viability and altered pharmacokinetics in mice lacking mdr1-type (drugtransporting) P-glycoproteins. Proc. Natl. Acad. Sci. USA 1997. 94:4028-4033

60. Seglen P.O. Preparation of isolated rat liver cells. Methods Cell Biol. 1976. 13:29-83

61. Sharma P.M., Bowman M., Madden S.L., Raischer F.J. $3^{\text {rd }}$., Sukumar S. RNA editing in the Wilms' tumor susceptibility gene, WT1. Genes Dev. 1994. 8(6):720-731

62. Sharom F.J., Liu R., Romsicki Y., Lu P. Insights into the structure and substrate interactions of the P-glycoprotein multidrug transporter from spectroscopic studies. Biochim. Biophys. Acta 1999. 1461: 327-345

63. Simpson I.A., Yver D.R., Hissin P.J., Wardzala L.J., Karnieli E., Salans L.B., Cushman S.W. Insulin-stimulated translocation of glucose transporters in the isolated rat adipose cells: characterization of subcellular fractions. Biochim Biophys Acta 1983. 763:393-407

64. Smit J.J., Schinkel A.H., Oude Elferink R.P., Groen A.K., Wagenaar E., van Deemter L., Mol C.A., Ottenhoff R., van der Lught N.M., van Roon M.A. homozygous disruption of the murine mdr2 P-glycoprotein gene leads to a complete absence of phospholipids from bile and to liver disease. Cell 1993. 75:451-462

65. Smith H.C., Gott J.M., Hanson M.R. A guide to RNA editing. RNA 1997. 3:1105-1123

66. Smith J.D., Freeman G., Vogt M., Dulbecco R. The nucleic acid of polyoma virus. J. Biol. Chem. 1960. 264:12053-12062

67. Southern E.M. Detection of specific sequences among DNA fragments separated by gel electrophoresis. J. Mol. Biol. 1975. 98:503-517 
68. Stefkova J., Poledne R., Hubacek J.A. ATP-binding cassette (ABC) transporters in human metabolism and diseases. Physiol. Res. 2004. 53:235-243

69. Theodoulou F.L., Holdsworth M., Baker A. Peroxisomal ABC transporters. FEBS Letters 2006. 580:1139-1155

70. Tombline G., Bartholomew L., Gimi K., Tyndall G.A., Senior A.E. Synergy between conserved ABC signature Ser residues in P-glycoprotein catalysis. J. Biol. Chem. 2004. 279:5363-5373

71. Tyzack J.K., Wang X., Belsham G.J., Proud C.G. ABC50 interacts with eukaryotic initiation factor 2 and associates with the ribosome in an ATP-dependent manner. J. Biol. Chem. 2000. 275:34131-34139

72. Ziemann C. Regulation der mdrlb-Expression in primären Rattenhepatozyten. Univ., Diss., Cuvillier Verlag 1998, Göttingen. 


\section{$7 \quad$ List of abbreviations}

ABC ATP-binding cassette

ABCB6 human ABC superfamily B subfamily member 6

ATP adenosine triphosphate

BLAST basic local alignment search tool

bp base pair

$\mathrm{Bq} \quad$ Becquerel

BSA bovine serum albumin

cDNA copy or complementary DNA

CIAP calf intestinal alkaline phosphatase

DAPI 4'-6-Diamidino-2-phenylindole

DMEM Dulbecco's modified Eagle medium

DMF dimethylformamide

DMSO dimethylsulfoxide

DNA deoxyribonucleic acid

dsDNA double strand DNA

DsRed Discosoma sp.

DTT dithiothreitol

ECL enhanced chemiluminescence

EDTA ethylene diamintetraacetic acid

EGFP enhanced green fluorescent protein

et al. et alteri

FCS fetal calf serum

FITC fluorescein-5-isothiocyanate

GAPDH glyceraldehyde-3-phosphate dehydrogenase

GFP green fluorescent protein

GTC guanidinium thiocyanate

G418 amino glycoside

Hmt1p heavy metal tolerance protein 1

HRP horseradish peroxidase

I.U. international unit 


\begin{tabular}{|c|c|}
\hline IPTG & isopropyl-beta-D-thiogalactopyranoside \\
\hline $\mathrm{kb}$ & kilo base pairs \\
\hline $\mathrm{kDa}$ & kilo Dalton \\
\hline LB & Luria-Bertani \\
\hline LM & low melting \\
\hline LSB & Laemmli sample buffer \\
\hline M & Molarity \\
\hline mAbcb6 & mouse $\mathrm{ABC}$ superfamily B subfamily member 6 \\
\hline MOPS & 3-[N-morpholino]-propane sulfuric acid \\
\hline mRNA & messenger ribonucleic acid \\
\hline NBF & nucleotide-binding fold \\
\hline OD & optical density \\
\hline PBS & phosphate buffered saline \\
\hline PCR & polymerase chain reaction \\
\hline PNK & polynucleotide kinase \\
\hline PVDF & polyvinylidendifluoride \\
\hline rAbcb6 & rat ABC superfamily B subfamily member 6 \\
\hline RACE & rapid amplification of cDNA ends \\
\hline $\mathrm{RE}$ & restriction enzymes \\
\hline RNA & ribonucleic acid \\
\hline RNase & ribonuclease \\
\hline rpm & round per minute \\
\hline RPMI & Roswell Perk Memorial Institute Medium \\
\hline RT & room temperature \\
\hline RT-PCR & reverse transcription -polymerase chain reaction \\
\hline SDS & sodium dodecyl sulfate \\
\hline SNPs & single nucleotide polymorphisms \\
\hline ssDNA & single strand DNA \\
\hline Taq & Thermophilus aquaticus \\
\hline TBE & Tris-borate-EDTA buffer \\
\hline TEMED & N,N,N',N'-tetramethylethylenediamine \\
\hline TES & Tris-EDTA-saccharose buffer \\
\hline $\mathrm{TM}$ & transmembrane \\
\hline Tris & Tris(hydroxymethyl)aminoethane \\
\hline
\end{tabular}


Tween 20 polyoxyethylene sorbitan- monolaureate

U Unit

UV Ultraviolet

$\mathrm{v} / \mathrm{v} \quad$ volume per volume

V5 viral epitope 5

$\mathrm{w} / \mathrm{v} \quad$ weight per volume

$\mathrm{xg} \quad$ acceleration of gravity

X-gal 5-brom-4-chlor-3-indolyl- $\beta$-galactoside

XLSA/A X-linked sideroblastic anemia and ataxia 


\section{Acknowledgments}

My special gratitude is to PD Dr. K. I. Hirsch-Ernst for a fascinating theme, constant interest in the project, noble and miscellaneous support of ideas that arose during the work on the project. In particularly I am thankful to Dr. Frauke Petry for helping me to get started and to Dr. Vera Ritz for constant and generous support in overcoming the major obstacles. I wish to thank P.D. Dr. Kramer and Prof. Dr. Fitzner for reviewing this thesis.

I am very grateful to Sonja Blume for extensive support during the work with Northern blots. I am deeply thankful to Christoph Schmitz-Salue for sharing highly valuable experience and knowledge of the Western blot and immunoprecipitation techniques with me. I am deeply grateful to Gudrun Rüdell for helping me with solving unexpectedly arising problems. I would like to thank Miranda Gonzalez-Aguirre for reading and correcting this thesis.

I am thankful to Prof. Dr. Brockmöller for the permission to use the ABI 3100 Sequencer and printer DeskJet 1220C. I am grateful to Cornelia Meineke, Dr. Mladen Tsvetkov, Dr. Frauke Petry, Karoline Jobst and Annett Kühne for technical support during sequencing experiments. And at last but not least, I would like to thank Bernd Gümpel for provided possibility to optimize the print of cellular images for this thesis. 


\section{Lebenslauf}

Persönliche Daten: Ana Jakimenko

Geboren am 09.03.1979 in Moskau, Russland

Staatsangehörigkeit: Litauisch

Ausbildung

06/1997 Abitur an der staatlichen Senvage-Schule, Vilnius, Litauen

Note 10 (entspricht Note 1 in deutschen Bewertungssystem)

09/1997 bis 07/2001 Bachelor-Studium der Biologie an der Universität Vilnius, Litauen BACHELOR THESIS: Zytogenetische Analyse von Patienten mit reaktiver und rheumatoider Arthritis.

Die Arbeit wurde angefertigt unter Anleitung von Prof. Dr. J. Lazutka.

09/2001 bis 07/2003 Master-Studium der Biologie an der Universität Vilnius, Litauen MASTER THESIS bei Prof. Dr. M. Mauricas:

Einfluß des Hepatitis-C-Genotyps und des Virämie Niveaus auf den Behandlungserfolg.

Seit $08 / 2003$

Mitgliedschaft im Graduiertenkolleg 335 „Klinische, zelluläre und molekulare Biologie innerer Organe“ mit dem Ziel der Promotion am Institut für Pharmakologie und Toxikologie der Georg-AugustUniversität Göttingen unter der Anleitung von PD Dr. K.I. HirschErnst

THEMA: Lokalisation und Dimerisation des Ratten-ABC-Halbtransporters, rAbcb6 im Vergleich zu rAbcb7

07/2006 Rigorosum (Note: Magna cum laude)

Stipendien

08/2003 bis 08/2006 Promotionsstipendium von der Deutschen Forschungsgemeinschaft. 